\title{
Trust in science and experts during the COVID-19 outbreak in Italy
}

\author{
Pietro Battiston*1, Ridhi Kashyap ${ }^{\dagger 2,3}$, and Valentina \\ Rotondi ${ }^{\ddagger 2,3}$ \\ ${ }^{1}$ University of Parma \\ ${ }^{2}$ Nuffield College, University of Oxford \\ ${ }^{3}$ Department of Sociology \& Leverhulme Centre for Demographic Science, \\ University of Oxford
}

May 8, 2020

\begin{abstract}
Trust in science and experts is extremely important in times of epidemics to ensure compliance with public health measures. Yet little is known about how this trust evolves while an epidemic is underway. In this paper, we examine the dynamics of trust in science and experts in real-time as the high-impact epidemic of Coronavirus (COVID-19) unfolds in Italy, by drawing on digital trace data from Twitter and survey data collected online via Telegram and Facebook. Both Twitter and Telegram data point to initial increases in reliance on and information-seeking from scientists and health authorities with the diffusion of the disease. Consistent with these increases, using a separately fielded online survey we find that knowledge about health information linked to COVID-19 and support for containment measures was fairly widespread. Trust in science, relative to trust in institutions (e.g. local or national government), emerges as a consistent predictor of both knowledge and containment outcomes. However, over time and as the epidemic peaks, we detect a slowdown and turnaround in reliance and information-seeking from scientists and health authorities, which we interpret as signs of an erosion in trust. This is supported by a novel survey experiment, which finds that those holding incorrect beliefs about COVID-19 give no or lower importance to information about the virus when the source of such information is known to be scientific.
\end{abstract}

JEL codes: I12, I20

Keywords: COVID-19, pandemic, trust, science, experts, survey experiment, digital traces.

*me@pietrobattiston.it

${ }^{\dagger}$ ridhi.kashyap@nuffield.ox.ac.uk

${ }^{\ddagger}$ valentina.rotondi@sociology.ox.ac.uk 


\section{Introduction}

Even in the public, that stubbornness to deny the plague was naturally giving way and losing itself as the disease spread, and spread because of contact and practice; and even more so when after having only been among the poor for some time, [the plague] began to touch better known people. Alessandro Manzoni, The Betrothed, ch. XXXI

The quote above comes from a 19th century Italian national literary classic in which the writer Alessandro Manzoni describes the plague outbreak in Milan in the 1630s. In the novel, Manzoni vividly writes about moments when the disease was already spreading but, due to misleading communication and mistrust in experts, few were inclined to take precautions for its containment. However, "the stubbornness to deny" the epidemic gave way, as the disease spread fast and the measures that were eventually taken to contain it were as dramatic as the epidemic itself. As the novel coronavirus (COVID-19) epidemic spreads across the world, Manzoni's characterisations of the dynamics of disease spread, public perceptions of it, and their willingness to respond to experts and modify behaviours, seem as relevant and important to understand today.

Scientific research has brought multifarious benefits to people's daily lives, and public trust in science and in experts should be a natural extension of science's cultural achievements (Barber, 1990). Moreover, trust in science and in scientific experts is essential to the functioning of modern, highly differentiated societies, where knowledge is highly specialized and complexity is constantly growing (Luhmann, 1979). Aligned with this, people across the world report fairly high levels of trust in science and in scientists (Gallup, 2019), and this trust often exceeds trust in other institutions such as government or media (Pew Research Center, 2019). Yet, the public health crisis triggered by the spread of the novel coronavirus (COVID-19) since December 2019, has occurred in a landscape when forces questioning science and the validity of expert opinions have gained greater visibility worldwide. In the recent past, the so-called vaccination backlash (Shetty, 2010) resulted in a return of measles in Europe and North America, and a broader environment of mistrust of scientific experts and tensions between politics and science have been noted in a number of countries and in the context of significant issues such as climate change (Nature, 2017; Larson, 2016).

Trust in science and in experts is particularly important in times of epidemics such as COVID-19. Although empirical research analysing the relationship between public health and public trust remains limited, existing 
literature indicates that variables linked to trust in experts and institutions (e.g. national and local governments) are important correlates of citizens' compliance with public health policies, restrictions and guidelines (Bavel et al., 2020; Vinck et al., 2019; Blair et al., 2017; Siegrist and Zingg, 2014; Gilles et al., 2011; Prati et al., 2011; Whetten et al., 2006). However, sustaining trust can be challenging in times of uncertainty and risk (Bavel et al., 2020; Siegrist and Zingg, 2014; Larson and Heymann, 2010). For example, in the early days of the Ebola epidemic in Western Africa in 2013, the lack of trust in healthcare providers led affected families to hide sick family members (Larson, 2016). Based on these experiences, the World Health Organization (WHO henceforth) cited the lack of trust in the health system as a major driver of the failure of the containment of the later Ebola outbreak (World Health Organization, 2019).

Understanding how trust in science and in experts evolves in the context of an unfolding epidemic is, therefore, crucial. Yet little is known about how trust evolves during an epidemic. How does trust in science and experts affect perceptions and knowledge about the disease while the epidemic is underway? How does trust in science and health experts - compared with trust in government institutions - affect the success of public health messaging and citizens' support for containment policies? Here, we address these questions by examining the dynamics of trust in science and experts in realtime as the high-impact epidemic of COVID-19 unfolds in Italy by leveraging complementary sources of digital trace and survey data (including a survey experiment) collected using three online platforms: Twitter, Telegram, and Facebook.

As of end-April 2020, Italy was one of the most severely affected countries by COVID-19. While each province in Italy had confirmed cases of the virus by mid-March 2020, the diffusion of the outbreak has been very heterogeneous with the majority of cases being concentrated in Lombardy, one of the wealthiest regions in the north of the country. Italian authorities have implemented draconian measures to tackle the COVID-19 outbreak. ${ }^{1}$ However, especially at the beginning of the outbreak, media reports suggested that the effectiveness of most of these measures was limited because the public received them with reluctance (Giuffrida and Cochrane, 2020). As Italy enters the next stage of the management of the epidemic and steps are taken to gradually loosen the 'lockdown' - and several other countries also confront this next stage - a deeper understanding of how public trust in science and experts has evolved over the course of the COVID-19 outbreak, as well as

\footnotetext{
${ }^{1}$ A description of the measures taken by the Italian government to contain the outbreak is given in Supplementary Information S1.
} 
the role of trust in shaping public attitudes towards public health measures in the context of an ongoing pandemic is vital.

Given the continued diffusion of COVID-19 and the heterogeneity in the levels of the contagion, Italy represents a relevant, timely, and interesting case study to examine how trust in science and experts unfolds during an epidemic. To understand these processes, we leverage primary data fielded through a pre-registered online survey collected in four waves via the popular messaging app, Telegram, as well as digital trace data on geo-localised Tweets. Using both these data sources, we first examine how the willingness to consult experts and authoritative sources of information regarding COVID-19 evolves over time and space as the epidemic spreads. Second, using a separate, pre-registered survey experiment fielded to a geographicallytargeted pool of Facebook users in Northern Italy with varying proximity to outbreak areas, we analyse beliefs and misperceptions regarding COVID-19 and assess if people's willingness to modify misperceptions with respect to the virus differs when the source of the same information is experimentally manipulated.

\section{Hypotheses}

Trust in experts and institutions is important in contexts where individuals lack the knowledge to make decisions and are unable to evaluate and understand the risks associated with a hazard (Siegrist and Cvetkovich, 2000). A public health crisis such as the COVID-19 outbreak provides such a setting, as existing research indicates that concepts linked to infectious diseases (e.g. herd immunity) are often poorly understood by the public (Zingg and Siegrist, 2012), and the outcomes of recommended behavioural measures for disease control are not clearly, nor immediately, visible (Betsch, 2020).

Although trust is theoretically important for the management of pandemics, it is also likely to be affected by the diffusion of the outbreak. The empirical literature on the dynamics of trust in science and experts in the context of crises is scant. There is some evidence, however, that crises can affect generalized trust and trust in authorities, but results point in different directions. In their study of the Ebola outbreak in West Africa in the three most affected countries of Guinea, Liberia, and Sierra Leon, Flückiger et al. (2019) found that trust in central government (parliament and president) and police increased in regions with higher exposure to the epidemic. Shupp et al. (2017) showed, for instance, that people who were affected by a tornado exert an increased level of general trust but also an increased level of trust in authorities and civil servants, such as police and firefighters. Evi- 
dence on how long effects of changes in trust last is also mixed. For example, Calo-Blanco et al. (2017) showed that trust and social cohesion increased after a large-scale earthquake but slowly weakened as environmental conditions improved over time. In contrast, Aassve et al. (2020) found that the spread of the Spanish flu of 1918 is negatively and significantly correlated with generalized trust in the United States today.

The above-mentioned studies examine trust outcomes after the crisis; how these changes occur as these events are underway is less well understood. An exception here is van der Weerd et al. (2011) who analysed the dynamics of trust in government during the $\mathrm{H} 1 \mathrm{~N} 1$ pandemic in the Netherlands and found that it decreased during the outbreak. The reasons recorded in their survey for weakening trust changed during the course of the pandemic, with the most reported reason being the perception that information was incomplete or withheld, to a belief in the later stage that the threat had been exaggerated by the government. Heterogeneity in the intensity of the outbreak may also affect dynamics of trust, as suggested by Fong and Chang (2011) who found that trust was not a significant predictor of community actions during the SARS outbreak in Taiwan where larger outbreaks occurred. These findings suggest that a perceived inability to control an outbreak may erode trust in authorities.

In light of the above, we hypothesize that, on average, trust and attention to scientific sources of information increase as a first reaction to the outbreak through an unconditional reliance on experts when facing an increased level of risk. However, this effect may begin to decrease over time as the epidemic continues to spread and as frustration against experts as well as authorities sets in who are perceived as unable to stop the diffusion of the disease. We anticipate that these dynamics of an increase followed by a stall to occur especially in areas that are affected at a later time, following a reversed Ushaped curve. In areas that are hit unexpectedly first, we expect frustration to erode trust as time from initial outbreak passes. ${ }^{2}$

At the individual level, we expect trust in science to be positively correlated with better knowledge about health information linked to the virus, as well as acceptance of containment policies. We expect that those who trust science are also more receptive to information derived from experts while those with weaker trust in science tend to trust even less the information coming from experts during an epidemic.

\footnotetext{
${ }^{2}$ These hypotheses were pre-registered: https://osf.io/txby2
} 


\section{Results}

\section{Trust dynamics during an epidemic}

We used the Twitter API to download all geo-located tweets posted between February 25 and April 15, 2020, including either of the three most popular hashtags related to the COVID-19 outbreak in Italy (further details in M4). Using this dataset, we study how social media attention given to scientists evolves over time and space as the virus spreads. We first focus on mentions to scientists' Twitter accounts to assess: 1) how attention given to scientists changes over time in the period between the end of February, when the first case of the virus is identified in Italy, until mid-April, by when Italy was widely believed to have passed the (first) peak, ${ }^{3}$ and 2) whether subjects located closer to cases of contagion are over-, or underrepresented - that is, if citizens from these areas have a specific propensity to mention scientists. We also compare changes in attention to scientists relative to other Twitter accounts from categories, including health authorities (e.g. WHO, Italian Institute for Public Health), authorities (e.g. government, regions, municipalities), politicians, media, and a residual category of other that regroups all accounts, for which increases in volume denotes a dispersion of attention away from those most closely associated with information on COVID-19.

Figure 1 and Table S3 in Supplementary Information S3.1 show the results of Ordinary Least Squares (OLS) regressions as described in section M4 in the Methods section. Figure 1 (first panel) and column (3) of Table S3 in Supplementary Information S3.1 show that trust in scientists, as proxied by Twitter mentions to scientists, increases with time as the disease outbreak spreads but then stalls. Further exploring the heterogeneity of this effect by the intensity of disease spread, we detect that this (non-monotonic) reversedU-shape pattern is driven by low and medium diffusion areas of the disease outbreak. The (non-monotonic) reversed-U shape also appears in Figure 2 (first panel) and column (1) of Table S4 where we focus on the average number of retweets (instead of mentions) per day for the three most mentioned scientist (Roberto Burioni, Ilaria Capua, Nino Cartabellotta) during the same period.

We further explore how attention paid to health authorities, authorities, politicians and media evolves over time and by disease intensity (columns 4-18 of Table S3 and columns $2-5$ of Table S4 in Supplementary Information S3.1). Figures 1 and 2 highlight the categories for which non-monotonic patterns of heterogeneity by time and disease intensity are statistically sig-

\footnotetext{
${ }^{3}$ See Figure S1 in S1 showing the level and the growth rate of the number of deaths tested positive for the COVID-19 in Italy during the course of the study.
} 
nificant. Similarly to scientists, we see initial increases in retweets of health authorities and authorities, as shown in Figure 2 over time, with a turnaround occurring in mid-March 2020, after the lockdown corresponding to the uptick in the number of deaths as shown in Figure S1 in S1. The volume of retweets of health authorities in particular is sizeable compared with the other two categories. Further, we see a shift in the categories that are mentioned over time, with decreasing attention to scientists and increases towards politicians. The biggest increases in mentions to politicians are in low to medium diffusion areas of the disease, which are the areas where mentions to scientists experience declines.

Figure 1: Evolution of Twitter mentions over time and space
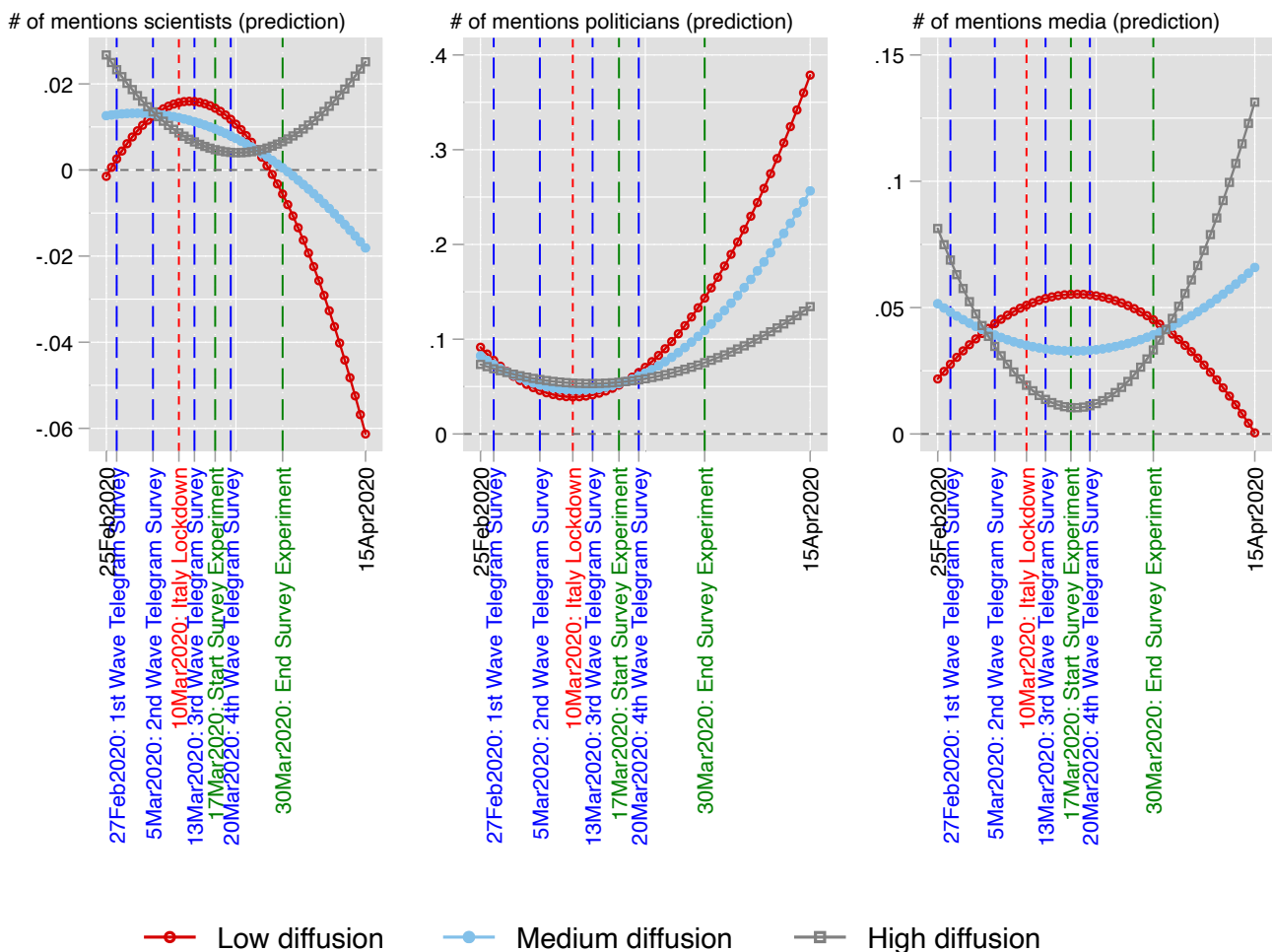

- Medium diffusion

High diffusion

Note: Marginal effect plots. OLS. Robust standard errors. Covariates (as described in Table S1 in the Supplementary Information S3.1) include Latitude and Total number of mentions. Low diffusion: $w c c=0$; High diffusion: $w c c=1$; Medium diffusion: $w c c=0.5$. wcc: Weighted cases count, i.e., per province-number of cases at date of tweet, weighted by the inverse of the square of the distance from each province. Results depicted in this figure are retrieved from column (3) of Table S3 in Supplementary Information S3.1. 
Figure 2: Evolution of Twitter retweets over time
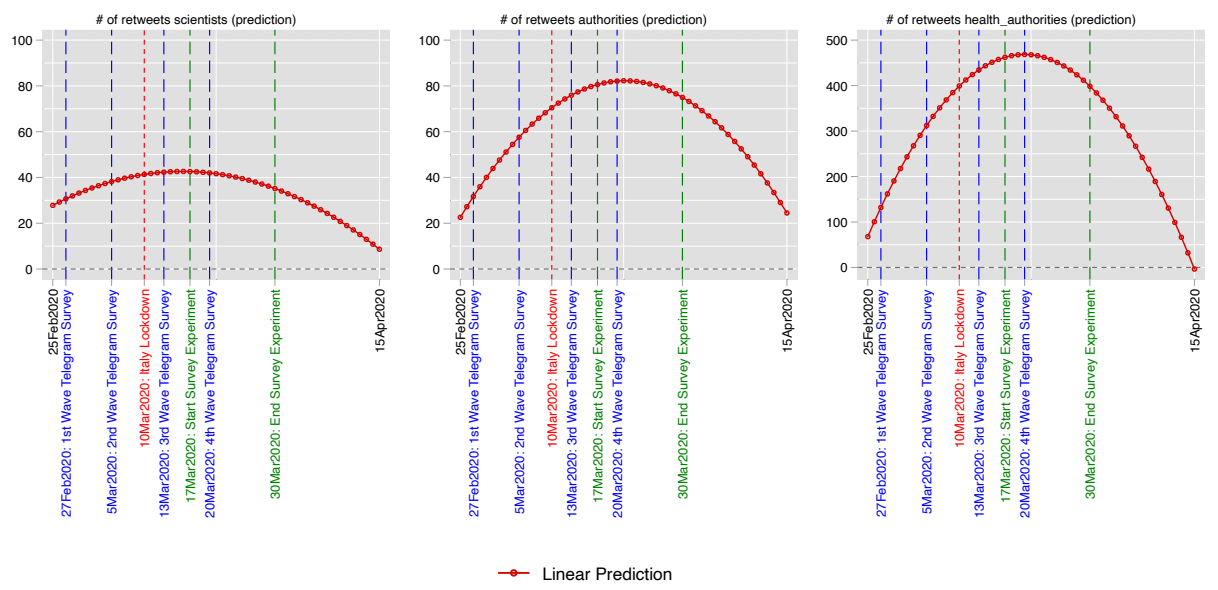

Note: Marginal effect plots. OLS. Robust standard errors. Covariates: time, time squared, total number of retweets. Results depicted in this figure are retrieved from column (1) of Table S4 in Supplementary Information S3.1.

Similar patterns are observed in the data we collected via an opt-in survey on the popular messaging app Telegram. In the survey, which was run on a channel of $60000+$ participants, we asked users about their desire (on a scale from 1 to 8 ) to receive information about the novel coronavirus from different sources, specifically: 1) doctors and scientists, 2) the government and local administration (authorities), 3) health authorities (e.g. WHO), and 4) celebrities (from show-business and sports). The first wave took place on February the 27th, 6 days after the discovery of the first case in Italy. The other waves were conducted on March 5, March 13 (just after the lockdown in Italy and corresponding to the descending path in the scientists panel on Figure 1 and to the the ascending path in the number of deaths, as shown in Figure S1 in S1), and March 20. Data from this survey allows us to directly track changes in self-reported preferences of individuals over time and space.

Figure 3 and Table S5 in Supplementary Information S3.2 summarise the results. Already at the first wave at the end of February, we observe that interest in receiving information from scientists and health authorities is higher than from other sources (authorities and celebrities). For each of the three categories of scientists, government authorities, and health authorities, there is a sizeable and significant overall increase of interest over time, and in several cases also from one wave to the following one; a decreasing pattern emerges instead for celebrities. However, both categories of experts scientists and health authorities - feature a U-shaped pattern by which inter- 
Figure 3: Summary of longitudinal evidence from Telegram survey
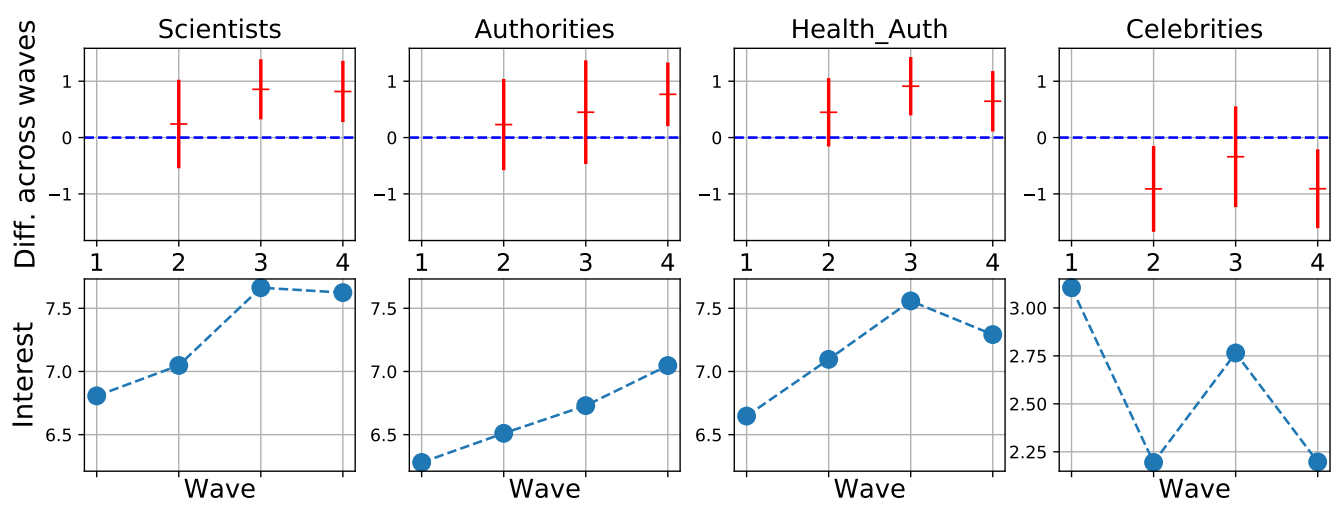

Note: responses to questions about desiring information on COVID-19 from specific sources. Bottom: average response for each wave (notice the different scale in the celebrities plot); top: difference between each wave and the first, with $95 \%$ confidence intervals. Post-stratification weights are applied to each wave to conform to the Italian population along demographic characteristics (age, gender, and education).

est increases until the third wave but then starts decreasing. Interest keeps increasing instead for authorities, perhaps unsurprisingly given the larger importance that public bodies bear when emergency laws are being put in place. For reference, the national lockdown was established on March 10, halfway through between the second and third wave.

Examining heterogeneity by outbreak intensity (as measured by the same indicator as in the Twitter analyses, weighted case count (wcc) per province as described in Section M5, Table S6 in Supplementary Information S3.2 suggests that people living in areas where the disease diffusion is higher are more willing to receive information from all categories but celebrities. This effect is statistically significant for information from scientists.

\section{Trust in science, compliance and willingness to update wrong beliefs}

We recruited via the Facebook ads platform a geographically targeted pool of online respondents and administered a pre-registered survey and a survey experiment. The exact wording of this survey's questions and of the treatment manipulation are reported in Supplementary Information S2.2. Our sampling strategy consisted of targeting 15 provinces in Lombardy (9) and Veneto (6), the two regions in northern Italy that were affected first by the pandemic. More specifically, our sampling strategy included a detailed ge- 
Figure 4: Relationship between trust variables, holding wrong beliefs about information linked to the coronavirus, and importance of containment policies
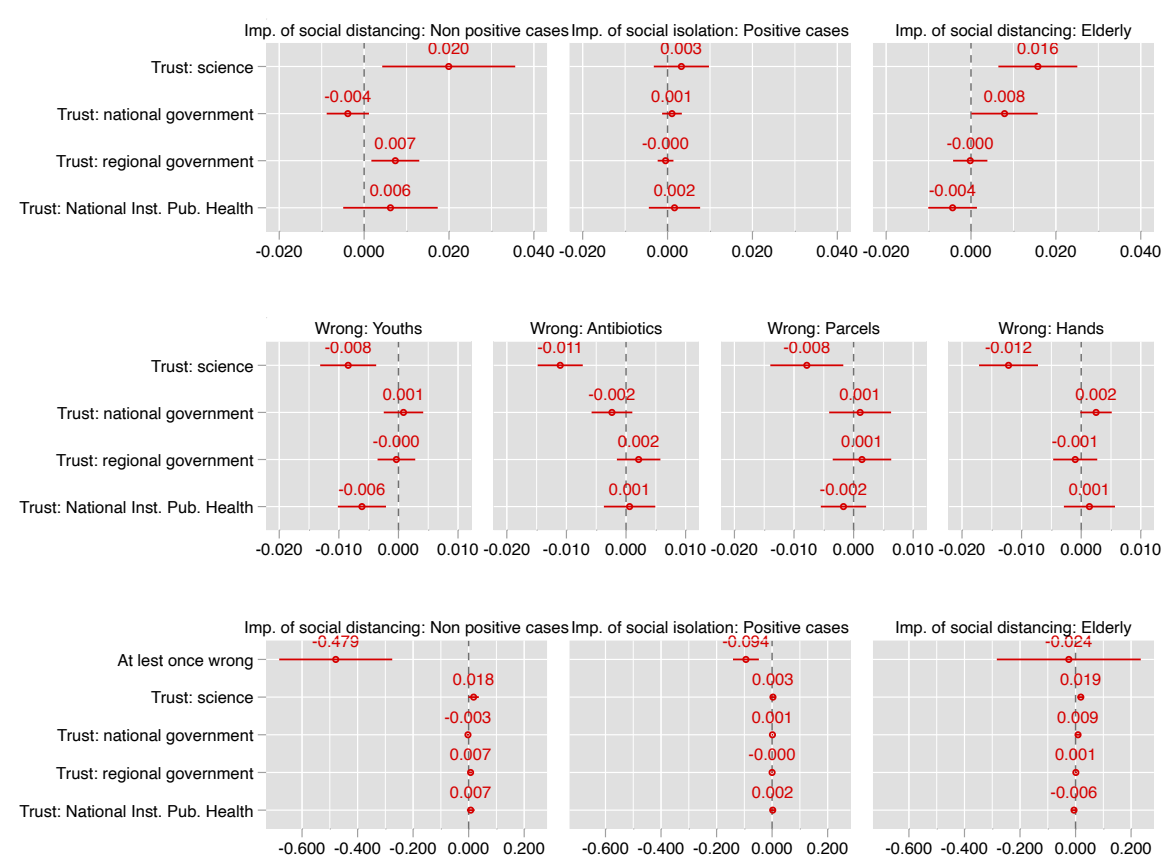

Note: Weighted OLS. Covariates (as described in Methods section M6) include: gender, age, dummies for educational attainment (secondary, bachelor, master and higher), dummies for marital status (married, cohabiting, divorced, widow), a dummy for having children, dummies for employment status (housewife, employed, retired, student, other), mathematical skills, self-placement of a left-right scale, a dummy for outbreak areas $(20 \mathrm{~km}$ radius from outbreak cities), a dummy for Lombardy, a dummy for Veneto, and Latitude. Buffers represent $95 \%$ confidence intervals. 


\footnotetext{
${ }^{4}$ See Supplementary Information S3.3 for a detailed description of the method of recruitment and sampling strategy adopted.

${ }^{5}$ Note that this survey, which is more detailed, was independently administered from the Telegram survey.

${ }^{6}$ The Italian Institute for Public Health is a scientific institution specifically aimed at promoting and protecting public health by carrying out research activities together with activities of public health training and monitoring. It serves as an external scientific body that advises the Ministry of Health, the Government, and the Regions with respect to public health issues. https://www.epicentro.iss.it/coronavirus/
} 


\footnotetext{
${ }^{7}$ The exact wording of these questions reads as follows: On a scale from 0 to 10 in order to reduce the spread of the virus, how it is important in your opinion to: 1) Reduce the movement of individuals even if they have not tested positive for the virus, 2) Home isolation for those who tested positive for the virus, 3) That older people avoid leaving their homes.

${ }^{8}$ When using in the same model trust in science, trust in institutions, and trust in the National Institute for Public Health, the only significant coefficient is that of trust in science.
} 


\footnotetext{
${ }^{9}$ Are younger people also at risk of contracting the coronavirus? Are antibiotics helpful in preventing the new coronavirus infection? Is it safe to receive parcels from China or other countries where the virus has been identified? Is washing hands really useful in preventing the coronavirus infection?

${ }^{10}$ Given the purposely localized targeting chosen for this analysis, distance from the initial outbreak areas can be interpreted both as a measure of duration of exposure and intensity of exposure.

${ }^{11}$ Our randomization worked well: see table S8 in Supplementary Information S3.3.
} 
Figure 5: Information and willingness to update wrong beliefs

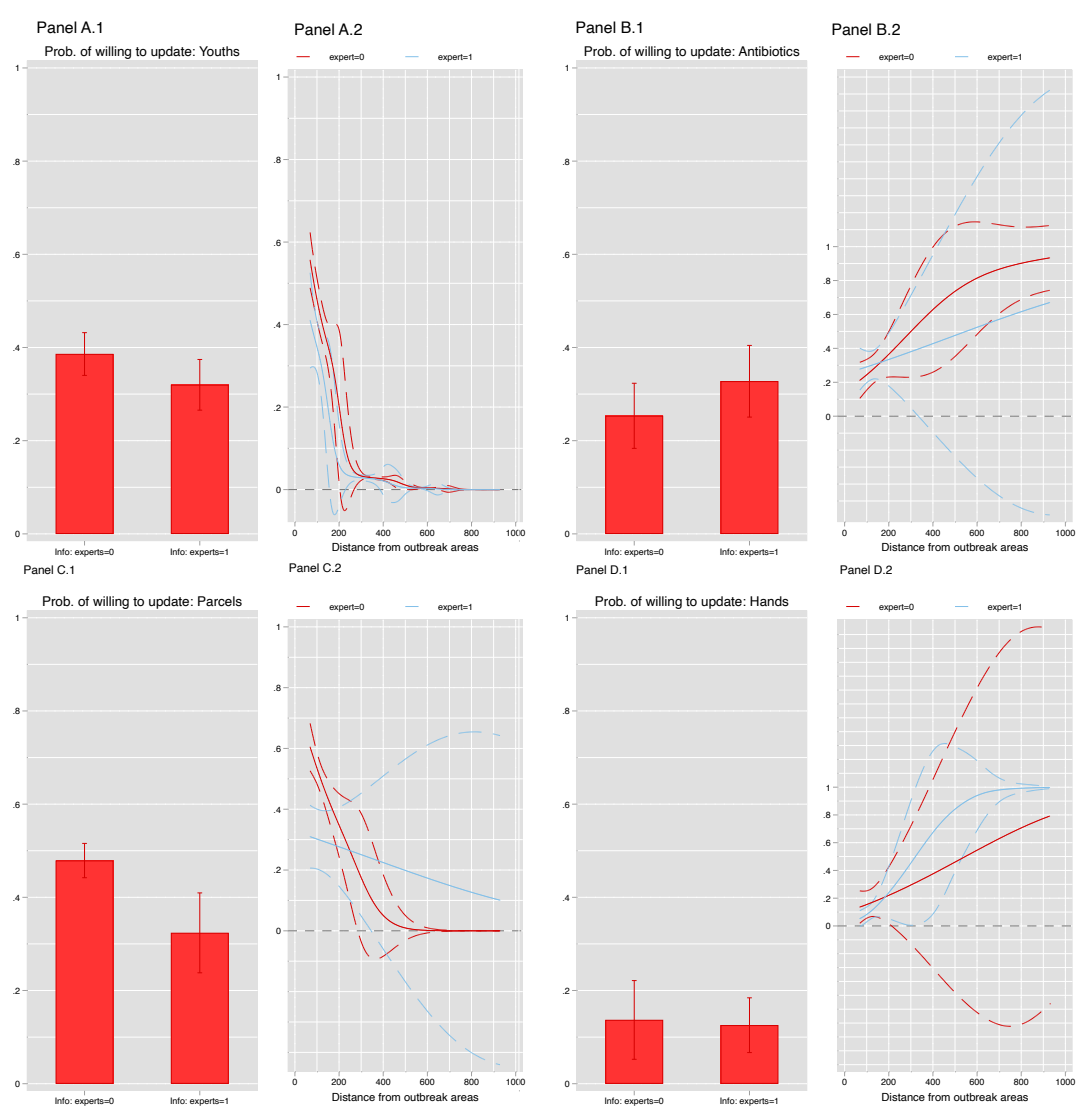

Note: Left panels: Marginal effect plots of treatment effects (reference to experts in the information received). Buffers represent $95 \%$ confidence intervals. Standard errors clustered at the province-level. Right panels: Interaction between information received by experts and distance from outbreak areas. Weighted Logit Marginal Effects. Covariates (as described in Table S7 in Supplementary Information S3.3) include: gender, age, dummies for educational attainment (secondary, bachelor, master and higher), dummies for marital status (married, cohabiting, divorced, widow), a dummy for having children, dummies for employment status (housewife, employed, retired, student, other), mathematical skills, self-placement of a left-right scale, a dummy for outbreak areas $(20 \mathrm{~km}$ radiuos from outbreak cities) or average distance from outbreak areas, a dummy for Lombardy, a dummy for Veneto, and Latitude. Buffers represent $95 \%$ confidence intervals. Wording of the questions reported in Supplementary Information S2.2. 
These main results are corroborated by a number of sensitivity tests where we make use of different measures of trust and of distance from early outbreak areas as described in Section M6 and as shown in Tables S10-S14, Tables S15S20, Tables S21 - S22, and in Tables S23-S26 in Supplementary Information S3.3.

Panels A.2, B.2, C.2, and D.2 of Figure 5 further show that the reluctance to update wrong beliefs in two out of four outcomes is more pronounced for those living closer to early outbreak areas (i.e., the red line being significantly higher than the light blue line in Panel A.2 and C.2 of Figure 5). This is consistent with an idea of erosion of trust in experts due to frustration as time passes and the disease outbreak spreads. These results experimentally corroborate the patterns suggested by the digital traces and the Telegram survey, which showed that during the period that our survey experiment was (unintentionally) fielded, indicators linked to trust in scientists and health authorities were descending.

\section{Conclusions}

Drawing on digital trace and survey data, our study shows how trust in experts has evolved in Italy in the context of the COVID-19 pandemic. Shortly after the identification of the first cases of COVID-19 in Italy in February 2020, both Twitter and Telegram data pointed to initial increasing attention and information-seeking from scientists and health authorities. However, we found a stall in this increase, and in particular on Twitter, where data are available over a longer period of time, we detected declines in social media attention to scientists and health authorities after mid-March 2020, taking the form of a reversed-U-shape.

Complementing Twitter and Telegram, we administered a separate survey to Facebook users geographically targeting two northern Italian regions with significant disease outbreaks to examine individual knowledge about the virus, support for containment policies, as well as experimentally assess trust in experts. The increasing willingness to consult expert sources, as suggested by the Telegram and Twitter data in the period leading up to the Facebook survey, was also reflected in knowledge outcomes. In the survey, we found generally high levels of public understanding of information about the disease as well as support for containment measures. Better knowledge was also correlated with greater support for containment measures.

However - echoing the signs of a declining levels of attention to scientists and health authorities in Twitter and Telegram - our survey experiment found that individuals with incorrect information about the virus were 
either not or less willing to correct it when receiving information from a scientific source than when the source of the same information was not explicitly stated. Examining geographical heterogeneity, we found that those living closer to early outbreak areas with longer exposure to the outbreak were less willing to update their incorrect beliefs.

Our findings, across the different, complementary data sources suggest an erosion of trust in scientists and scientific authorities in Italy with longer exposure to the COVID-19 pandemic. Following from our hypotheses, we interpret these dynamics to suggest that over time, and with continued disease diffusion and inability to curb it, frustration emerges that weakens trust. In the survey experiment, this effect is most clear in areas close to the early outbreaks areas and that witnessed already two weeks of quarantine. In these areas, although average levels of knowledge about the virus and support for containment was high, with time by late-March, a lack of willingness to modify beliefs in response to expert information appeared among those holding incorrect beliefs. Although by the time of the survey experiment we did not see this effect in other areas, these results suggest that it may appear with longer duration of exposure and if perceptions of an inability to manage the outbreak also take root in other places.

A shortcoming of our data is that they do not enable us to disentangle the mechanisms behind the erosion of trust. While we hypothesize that the inverted U-shape would be caused by a mechanism of frustration with the inability to curb an epidemic, we nevertheless recognize that potentially fragmented scientific communication (due to the often heterogeneous positions about the coronavirus among experts themselves) is also a plausible mechanism for the erosion of trust. Indeed, the results of a poll conducted by an Italian observatory on trust in science in March and April 2020 show that public opinion about scientists communication activities in Italy was divided (Observa Science in Society, 2020). Almost one Italian out of two believed that the diversity of opinions given by experts in their interventions created confusion (48\%); and $8 \%$ positively acknowledged the competence of the Italian scientific experts in the merit, while negatively assessed their communicative ability. The same study, however, shows that perceptions about risk did not diminish, but instead increased over the period between March and April, as did the share of those supporting the idea of staying at home.

It is nonetheless plausible that different mechanisms underlie frustration in different areas, varying by the extent of their local outbreaks. For example, in high intensity areas, where our survey experiment was administered, longer exposure without resolution may erode trust, whereas in low-intensity areas, a weaker perception of a threat and the continuation of stringent containment 
measures may affect trust. This latter pattern is suggested by the Twitter data, where the reversed-U-shape in attention to scientists is driven by lowand medium-intensity outbreak areas. Our results nevertheless suggest that, although in the face of a new threat, trust and reliance on scientists and experts increases - continued trust is not inevitable, and trust is itself affected by the dynamics of the pandemic. Even when the pandemic is underway, our results point to the importance of trust in science and public health authorities, which emerges as a resilient predictor of both public health knowledge and containment support. To sustain public trust in science throughout a crisis, our study points to the need for clear, sustained and transparent channels of information communication from scientific authorities to the public to anticipate and guard against frustration.

Author contributions All authors contributed equally to this work. PB, RK and VR conceived and designed the research. PB, RK and VR developed analysis plan. VR and PB analysed the data. PB, RK and VR wrote the paper.

Acknowledgements All authors wish to thank the owners of the@Ultimora Telegram channel, Luigi Buraschi and Paolo Allegro, for their support in this research, and Luca Stanca for useful inputs. We are grateful for the financial support of Nuffield College, and technical and administrative support provided by the team at Centre for Experimental Social Sciences at Nuffield College, including Raymond Duch, Thomas Robinson, Noah Bacine, Melanie Sawers, and Chandru Swaminathan. We thank participants of (virtual) seminars of the DisCont research group at Bocconi University, the economics group at the University of Cagliari, and the Nuffield College Sociology Group for constructive feedback. RK and VR are supported by the Leverhulme Trust, Leverhulme Centre for Demographic Science.

\section{Methods}

\section{M1 Ethical approval and informed consent}

This study was approved by the University of Oxford Central University Research Ethics Committee (Reference number: R68769/RE001) and has been run in accordance with rules and procedures of the Centre for Experimental Social Sciences (CESS) at Nuffield College in the University of Oxford. These are described at the following link: https://cess-nuffield.nuff.ox.ac. 
uk/experiments/for-researchers/. The study received also external ethical review through the CESS ethics committee. All participants provided written informed consent prior to enrolment in the study. A copy of the consent form is reported in Supplementary Information S3.3.

\section{M2 Pre-registration}

The hypotheses and methods used in the study have been pre-registered. A copy of the original documentation is available at this link: https://osf. io/8bhn4/ with the following DOI: 10.17605/OSF.IO/TXBY2

\section{M3 Data and methods}

We employed multiple approaches of data collection.

\section{M4 Twitter Analysis}

The sample of geo-located tweets was obtained by downloading through the Twitter API all tweets posted between February 25 and April 15, 2020, containing at least one of the three most popular hashtags linked to the COVID19 outbreak in Italy: \#coronavirusitalia, \#covid19italia, and \#covid19italy.

This resulted in 12232 tweets, posted by 4755 unique users. Each tweet has on average 0.43 mentions, that is, references to other Twitter accounts, resulting in a total of 5318 mentions. First, all profiles mentioned 3 times or less were flagged as "unclassified". Then, a category "foreigner" was made to include all individual accounts (hence excluding media outlets and health organizations) that mostly tweeted in languages other than Italian. Then, all 362 remaining accounts were manually classified into the following categories: "politicians", "scientists", "authorities", "health authorities", "media", "journalists" and a residual category "other". All categories defined this way are mutually exclusive.

The "authorities" category includes official accounts of public entities such as Twitter accounts of government, regions, municipalities, as well as embassies; the "health authorities" category includes authorities and institutes focusing on health, such as the Italian Health Institute and the World Health Organization (WHO)); the "scientists" category includes instead only personal accounts of individual scientists and researchers, regardless of whether the owner holds a position in hospitals, universities, research centres or public administration.

The resulting data are analysed using the following model: 


$$
\text { Category }=\beta_{0}+\beta_{1} w_{c c}+\beta_{2} \text { time }+\beta_{3} \text { time }{ }^{2}+\beta_{4} \text { total }+\beta_{5} \text { latitude }
$$

where category is the number of mentions to Twitter users in a given class, $w c c$ is a measure of the intensity of the diffusion of the disease and is calculated as the per-province number of cases at date of tweet, weighted by the inverse of the square of the distance from each province, and total is the total number of mentions (to users in any category) as a control for overall Tweet volume. The model specification includes also latitude to account for the well-known North-South Italian gradient in behaviors. Equation (1) is estimated using OLS with standard errors robust to heteroskedasticity.

The sample of retweets is composed by the retweets for the three most cited accounts within each category ${ }^{12}$ in each category in the previously described dataset. This resulted in 54,263 retweets. Each tweet has on average 67 retweets, resulting in a total of 3,239,575 retweets. Retweets are analysed by estimating Equation (2) using OLS with standard errors robust to heteroskedasticity.

Summary statistics for our two Twitter datasets are depicted in Tables S1 and S2 is Supplementary Information S3.1.

$$
\text { Category }=\beta_{0}+\beta_{1} \text { time }+\beta_{2} \text { time } e^{2}+\beta_{4} \text { total }
$$

\section{M5 Continuous survey via Telegram}

Each wave of the interview was triggered by sending an invitation in a popular Telegram channel, covid19, dedicated to the diffusion of news (in Italian) about the pandemic. During the days elapsed between the first and the fourth wave, the channel grew from around 50,000 to around 70,000 members. In total, we obtained 3,925 valid participant/wave combinations. The exact wording of the questions asked during the 4 waves of the data collection via Telegram is reported in the Supplementary Information S2.1. The first three waves were conducted entirely within the Telegram app, through a bot that interacted with participants asking the questions in sequence. In the fourth wave of the Telegram survey, in addition to the usual questions, an abbreviated form of the survey experiment administered to Facebook users was run on the Telegram pool by directing users to a Google Form survey.

\footnotetext{
${ }^{12}$ Roberto Burioni, Ilaria Capua, Nino Cartabellotta for scientists, the Civil Protection, the President of the Republic and the Lombardy Region for authorities, the Ministry of Health, the WHO and the Red Cross for health authorities, the Change petitions website, the Serie A football league and the Pope's Italian account for "other".
} 


\footnotetext{
${ }^{13}$ Information retrieved from the Facebook ads API indicates there are 30 million Facebook monthly active users over the age of 18 as of April 21, 2020
} 
We targeted specific municipalities, including both the early outbreak areas as well as those surrounding them, in the two provinces of Lombardy and Veneto, as described in further detail in Section S3.3. Respondents that opted in and clicked the ad were enrolled into the subject pool for the Centre for Experimental Social Sciences at Nuffield College. To minimise topical self-selection (Lehdonvirta et al., 2020) (e.g recruiting respondents with unusually greater interest in the coronavirus), our recruitment ad avoided any mentions to the content of our survey and only implied that survey respondents were sought for the CESS subject pool. Subsequently, the survey link was sent out to all those who entered the subject pool through the ad, and was administered via Qualtrics. The survey ran from March the 17th to March the 30th and we received a total of 994 completed responses. The exact wording of the questions administered is reported in the Supplementary Information S2.2.

The data have been analysed using the following model:

$$
\text { Outcome }_{i}=\alpha+\delta_{1 i}+\delta_{2 i}+\delta_{3} \times Z_{c, l}+\epsilon_{i}
$$

Where Outcome $_{i}$ is the outcome of interest, $\delta_{1 i}$, and $\delta_{2 i}$ are a set of control variables including gender, age, dummies for educational attainment (secondary, bachelor, master and higher), dummies for marital status (married, cohabiting, divorced, widow), a dummy for having children, dummies for employment status (housewife, employed, retired, student, other), mathematical skills, self-placement of a left-right scale, a dummy for Lombardy, a dummy for Veneto, and Latitude. The models include also a measure of distance from early outbreak areas computed as follows: we geo-localized respondents based on their ZIP codes and we calculated for each respondent the average distance from the three main early outbreak municipalities of Codogno (Province of Lodi, Lombardy Region), Nembro (Province of Bergamo, Lombardy Region), and Vo' Euganeo (Province of Padua, Veneto Region). In some specifications we used, instead of the average distance, a dummy variable assuming value 1 if respondents were located within a radius of $20 \mathrm{Km}$ from the three initial outbreak municipalities. The estimated models also include measures of trust in science and institutions as described in Table S7 in Supplementary information S3.3. Note that a cross-correlation table for these measures is depicted in Table S9 in Supplementary information S3.3.

Table S7 in Supplementary information S3.3 show the summary statistics for the variables used along the empirical analysis. We estimate our models either through OLS or Logit models (marginal effects) with robust standard errors clustered at the province-level. We refer the reader to the Supplementary Information S3.3 for an in-depth description of the data and of the 


\section{${ }_{591} \quad$ M7 Software}

592 The models estimations and plots were done in part with Stata and in part

sensitivity checks conducted.

Research on the Italian setting has shown that Facebook is an effective survey recruitment tool that did not indicate any systematic demographic or psychometric biases (Kalimeri et al., 2020). Nonetheless, to account for potential demographic biases of an online, non-probability sample, our analyses applied post-stratification weights by age, gender and education to conform our sample to the Italian population. with Python, using the statsmodels, pandas, matplotlib and ipfn libraries. 


\section{References}

Aassve, A., G. Alfani, F. Gandolfi, and M. L. Moglie (2020). Epidemics and trust: The case of the spanish flu. IGIER WP series (661).

Barber, B. (1990). Social studies of science. Transaction Publishers.

Bavel, J. J. V., K. Baicker, P. S. Boggio, V. Capraro, A. Cichocka, M. Cikara, M. J. Crockett, A. J. Crum, K. M. Douglas, J. N. Druckman, J. Drury, O. Dube, N. Ellemers, E. J. Finkel, J. H. Fowler, M. Gelfand, S. Han, S. A. Haslam, J. Jetten, S. Kitayama, D. Mobbs, L. E. Napper, D. J. Packer, G. Pennycook, E. Peters, R. E. Petty, D. G. Rand, S. D. Reicher, S. Schnall, A. Shariff, L. J. Skitka, S. S. Smith, C. R. Sunstein, N. Tabri, J. A. Tucker, S. v. d. Linden, P. v. Lange, K. A. Weeden, M. J. A. Wohl, J. Zaki, S. R. Zion, and R. Willer (2020). Using social and behavioural science to support covid-19 pandemic response. Nature Human Behaviour.

Betsch, C. (2020). How behavioural science data helps mitigate the covid-19 crisis. Nature Human Behaviour, 1-1.

Blair, R. A., B. S. Morse, and L. L. Tsai (2017). Public health and public trust: Survey evidence from the Ebola Virus Disease epidemic in Liberia. Social Science 85 Medicine 172, 89-97.

Buonanno, Paolo, Sergio, Puca, and Marcello (2020, Apr). Estimating the severity of covid-19: Evidence from the italian epicenter. SSRN.

Calo-Blanco, A., J. Kovářík, F. Mengel, and J. G. Romero (2017). Natural disasters and indicators of social cohesion. PloS one 12(6).

Flückiger, M., M. Ludwig, and A. Sina Önder (2019). Ebola and state legitimacy. The Economic Journal 129(621), 2064-2089.

Fong, E. and L.-y. Chang (2011). Community under stress: Trust, reciprocity, and community collective efficacy during sars outbreak. Journal of community health 36(5), 797-810.

Gallup (2019). Wellcome global monitor - first wave findings. Technical report.

Gilles, I., A. Bangerter, A. Clémence, E. G. Green, F. Krings, C. Staerklé, and P. Wagner-Egger (2011). Trust in medical organizations predicts pandemic (h1n1) 2009 vaccination behavior and perceived efficacy of protection measures in the swiss public. European journal of epidemiology 26(3), 203-210. 
Giuffrida, A. and L. Cochrane (2020, Feb). Italy imposes draconian rules to stop spread of coronavirus. https://www. theguardian.com/world/2020/feb/23/ italy-draconian-measures-effort-halt-coronavirus-outbreak-spread.

Kalimeri, K., M. G. Beiró, A. Bonanomi, A. Rosina, and C. Cattuto (2020). Traditional versus Facebook-based surveys: Evaluation of biases in selfreported demographic and psychometric information. Demographic Research 42(5), 133-148.

Larson, H. J. (2016). Vaccine trust and the limits of information. Science 353(6305), 1207-1208.

Larson, H. J. and D. L. Heymann (2010). Public health response to influenza a (h1n1) as an opportunity to build public trust. Jama 303(3), 271-272.

Lehdonvirta, V., A. Oksanen, P. Räsänen, and G. Blank (2020). Social media, web, and panel surveys: Using non-probability samples in social and policy research. Policy \& Internet.

Luhmann, N. (1979). Trust and power. John Wiley \& Sons.

Nature (2017, May). Beware the anti-science label. Nature 545(7653), 133134.

Observa Science in Society (2020, Apr). Gli italiani e il coronavirus: i nuovi dati dell'osservatorio. url=https://www.observa.it/gli-italiani-e-ilcoronavirus-i-nuovi-dati-dellosservatorio.

Pew Research Center (2019). Trust and mistrust in americans' views of scientific experts. Technical report.

Prati, G., L. Pietrantoni, and B. Zani (2011). Compliance with recommendations for pandemic influenza h1n1 2009: the role of trust and personal beliefs. Health education research 26(5), 761-769.

Rotondi, V., L. Andriano, J. B. Dowd, and M. C. Mills (2020). Early evidence that social distancing and public health interventions flatten the covid-19 curve in italy. OSF Preprints 26.

Shetty, P. (2010). Experts concerned about vaccination backlash. The Lancet 375(9719), 970-971.

Shupp, R., S. Loveridge, M. Skidmore, J. Lim, and C. Rogers (2017). Trust and patience after a tornado. Weather, climate, and society 9(4), 659-668. 
Siegrist, M. and G. Cvetkovich (2000). Perception of hazards: The role of social trust and knowledge. Risk analysis 20(5), 713-720.

Siegrist, M. and A. Zingg (2014). The role of public trust during pandemics. European psychologist.

van der Weerd, W., D. R. Timmermans, D. J. Beaujean, J. Oudhoff, and J. E. van Steenbergen (2011). Monitoring the level of government trust, risk perception and intention of the general public to adopt protective measures during the influenza a (h1n1) pandemic in the netherlands. $B M C$ public health 11(1), 575.

Vinck, P., P. N. Pham, K. K. Bindu, J. Bedford, and E. J. Nilles (2019). Institutional trust and misinformation in the response to the 2018-19 ebola outbreak in north kivu, dr congo: a population-based survey. The Lancet Infectious Diseases 19(5), 529-536.

Whetten, K., J. Leserman, R. Whetten, J. Ostermann, N. Thielman, M. Swartz, and D. Stangl (2006). Exploring lack of trust in care providers and the government as a barrier to health service use. American journal of public health 96(4), 716-721.

World Health Organization (2019). WHO director-general praises bravery of health workers during visit to eastern democratic republic of congo following fatal attacks on ebola responders. https://www.who.int/news-room/detail/ 01-12-2019-who-director-general-praises-bravery-of-health-workers-during-visi

Zingg, A. and M. Siegrist (2012). Measuring people's knowledge about vaccination: developing a one-dimensional scale. Vaccine 30(25), 3771-3777. 


\section{Supplementary Information}

\section{S1 Coronavirus pandemic and containment measures adopted by the Italian government in the aftermath of the outbreak}

On Friday 21st the first case of Coronavirus was discovered in a town located in the province of Lodi, in the region of Lombardy in northern Italy. Almost simultaneously another Italian citizen from a small municipality in the province of Padua, in the Veneto region, was found to be positive for the Coronavirus. Two days later, on February 23, the government issued a decree which prohibited the movement of people outside 10 municipalities located in Lombardy and a municipality in Veneto, all indicated in red in Figure S7. However, the decree did not have immediate implementation. The control plan did not start rigidly, and checkpoints were not very effective: in fact, there were numerous leaks towards other provinces and regions in southern Italy. Law enforcement officers (at least 500 men) were deployed two days later in order to avoid further leaks. Although cases in the province of Bergamo began also to increase at an alarming rate, in contrast to Lodi, no further shutdowns or restrictions were imposed. In the following days, despite constant calls to limit travel and to adopt preventive measures such as avoiding gatherings and enclosed spaces, many Italians took advantage of the temporary closure of the schools decided by the government, to move to the mountains or to the sea. From March the 8th the restriction to avoid any movement was extented to the whole of Lombardy and to fourteen provinces of Veneto, Emilia Romagna, Piedmont, and Marche. The decree, however, was leaked by the press already in the late evening of March the 7th, generating panic and once more substantial movement of people from the northern regions towards the south. On March the 10th, a new decree of the Prime Minister Giuseppe Conte, extended these lockdown measures across the entire country of Italy until May the 4 th when the country started a mild reopening.

In the week that followed the discovery of the first case, Italy experienced a very rapid increase in the number of cases and deaths (See figure S1). This growth was uneven with the majority of cases (and deaths) being concentrated in the north of the country and, particularly, in Lombardy which roughly counts half of the total number of deaths (see right panel of Figure S1. As a yardstick, on February the 27th (the day of the first Telegram survey) the cumulative number of deaths amounted to 10. By the end of the fourth wave of the Telegram survey Italy had registered 4000 deaths. 
Accordingly, at the beginning of the survey experiment (which took place entirely after the lockdown) Italy had witnessed more then 1000 deaths, by the end of the survey they were more than 11000 .

Figure S1: Deaths Italy (left panel) and selected regions (right panel)
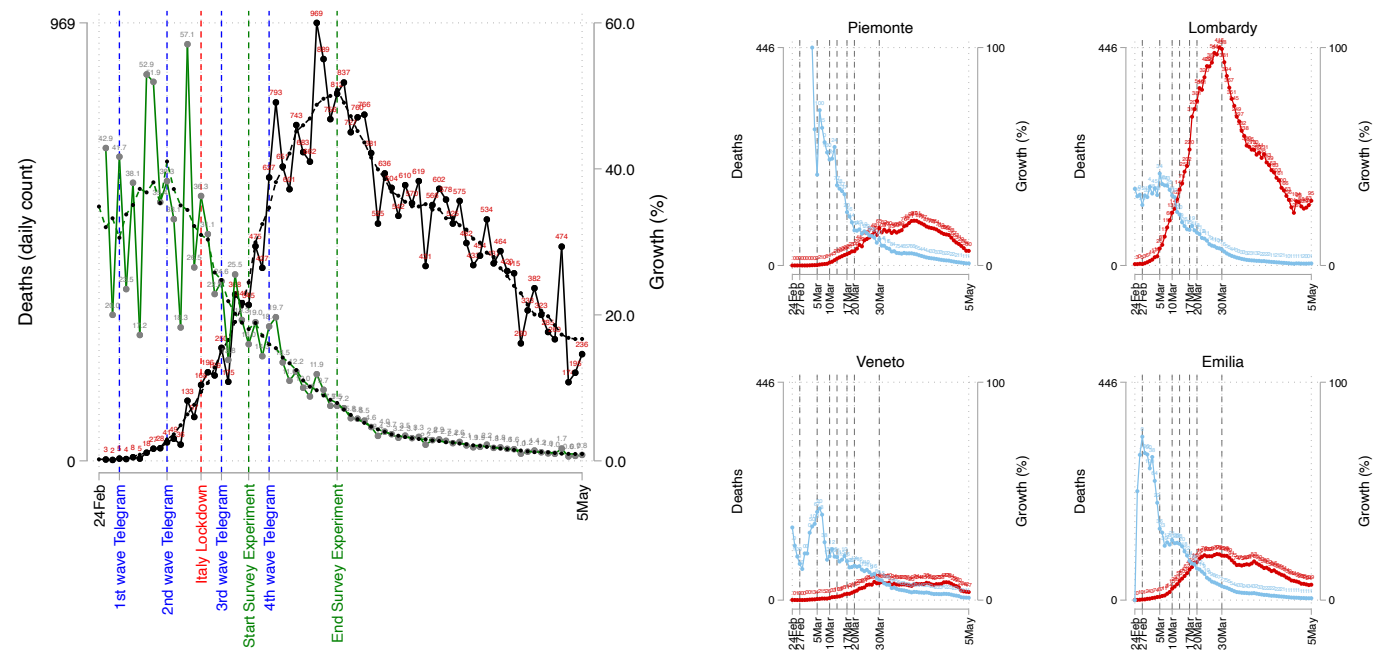

Note: Levels and Growth Rate (moving averages 7 days). Data are available at the following link: https://github.com/pcm-dpc/COVID-19

\section{S2 Questionnaires}

\section{S2.1 Continuous survey via Telegram}

The following questions (translated from Italian) have been asked. Not all questions will be asked in all waves.

- Between 0 and 100, what do you estimate is the percentage of patients hospitalized in intensive care wards, among positive Coronavirus cases, in Italy? (Tra 0 e 100, quale stimi sia il tasso percentuale di ricoverati in terapia intensiva (tra i contagiati) in Italia?)

- Between 0 and 100, what do you estimate is the percentage of casualties, among positive Coronavirus cases, in Italy? (Tra 0 e 100, quale stimi sia il tasso percentuale di mortalità (tra i contagiati) in Italia?)

- Please indicate, with a number from 1 to 8 , your desire to be informed concerning statements on the new Coronavirus... (Ti invito a indicare, 
con un numero da 1 a 8, quanto desideri rimanere aggiornato sulle dichiarazioni riguardanti il nuovo Coronavirus...)

- ...from doctors and scientists (di medici e scienziati)

- ...from the government and local administrations (del governo e delle amministrazioni locali)

- ...from international health institutions (WHO) (delle autorità sanitarie internazionali (OMS))

- ...from famous persons from the show business and sports (di celebrità dello spettacolo e dello sport)

Participants were then asked to provide information on

- their age ("1-13", "14-29", "30-44", "45-64", "65 or more" ("65 o più"))

- their gender ("male ("maschio", "female" ("femmina"), "other/prefer not to say" ("altro/preferisco non dire"))

- level of studies ("primary/middle school" ("medie/elementari"), "higher school"("diploma superiore"), "university degree"("laurea"), "master or higher" ("post-laurea"))

- their ZIP code ("il suo CAP")

\section{S2.2 Survey Experiment via Facebook}

Grazie per la tua partecipazione a questo progetto di ricerca. Sei stato invitato a partecipare ad una ricerca sulla tua percezione della scienza e degli esperti. Questo studio è messo a punto e realizzato da Pietro Battiston (Università di Parma), Ridhi Kashyap (Università di Oxford e Nuffield College) e Valentina Rotondi (Università di Oxford e Nuffield College) in collaborazione con il Centro per le Scienze Sociali Sperimentali (CESS-Centre for Experimental Social Sciences) del Nuffield College e dell'Università di Oxford.

Durante questa ricerca, potremmo chiederti di rispondere ad alcune domande riguardanti le tue caratteristiche demografiche, il tuo orientamento politico, e la tua opinione su alcuni aspetti riguardanti la salute. Inoltre, ti saranno date alcune informazioni riguardanti la salute. La ricerca durerà circa 15 minuti. La tua partecipazione a questa ricerca è interamente volontaria. Potrai pertanto ritirare il tuo consenso ed uscire dalla ricerca in qualsiasi momento. Non inganniamo i partecipanti, qualsiasi promessa fatta ai soggetti nel corso dello studio sarà confermata dal ricercatore. Se completerai tutto 
il sondaggio, riceverai il pagamento pari a 3.5 euro. La politica del CESS e i regolamenti IRB, prevedono che potremmo dover raccogliere il tuo nome, indirizzo, codice fiscale e firma prima di darti il tuo compenso.

Riteniamo che non vi siano rischi noti associati a questa ricerca se non quelli che potresti incontrare nella vita di tutti i giorni; tuttavia, come per qualsiasi attività online, il rischio di violazione è sempre possibile. A questo scopo faremo tutto il possibile affinché la tua partecipazione a questa ricerca rimanga confidenziale. I dati che pubblicheremo saranno solo dati anonimi e faremo del nostro meglio per mantenere riservate le tue informazioni. La protezione dei dati è in linea con il regolamento generale sulla protezione dei dati, i ricercatori avranno accesso solo a dati anonimizzati, i dati resi anonimi saranno accessibili solo al CESS e saranno archiviati in un database sicuro dopo il pagamento. Inoltre, tali dati personali non verranno mai ceduti a terzi se non nella misura richiesta dalla legge. I risultati di questo studio saranno utilizzati a scopi accademici.

In caso di domande sulla ricerca, contattaci sul nostro indirizzo email: cessonline@nuffield.ox.ac.uk oppure contatta Valentina Rotondi all'indirizzo: valentina.rotondi@socio Se vuoi avere ulteriori informazioni sul trattamento etico dei nostri dati visita il sito: https://www.youtube.com/watch?v=nkPA3fb6K84\& feature=youtu.be Questa ricerca è stata approvata secondo le procedure CESS IRB per la ricerca su soggetti umani.

Ho letto le informazioni sopra. Cliccando su "si" dichiaro che ho compreso quello che ho letto sopra e confermo la mia partecipazione a questo studio.

- Si (Yes)

- No (No) 
Thank you for your participation in this research project. You are being invited to participate in a research study about you perceptions about science and experts. This study is being done by Pietro Battiston (University of Parma), Ridhi Kashyap (University of Oxford and Nuffield College) and Valentina Rotondi (University of Oxford and Nuffield College) in collaboration with the Centre for Experimental Social Sciences (CESS), Nuffield, the University of Oxford.

During the course of the study, we may ask about, demographics, political ideology, and your opinion on various health-related matters. In addition, you may be provided with information on various health related topics. The research study will take you approximately 15 minutes to complete. Your participation in this study is entirely voluntary and you may withdraw at any time from this study. We do not deceive participants, any promise made to subjects during the course of the study will be upheld by the researcher. If you complete the survey, you will receive your payment amounting to 3.5 euros. Due to CESS policy and IRB regulations, we may have to collect your name, address, fiscal code, and signature in order to give you this compensation.

We believe there are no known risks associated with this research study other than those encountered in everyday life; however, as with any online related activity the risk of a breach is always possible, to the best of our ability your participation in this study will remain confidential, and only anonymised data will be published. We will do our best to keep your information confidential. Data protection is in line with GDPR, researchers will only have access to anonymized data, deanonymized data will only be accessible by CESS and will be stored in a safe database after payment is complete. Also, that personal data will never be given to a third party except to the extent required by law. The results of this study will be used for scholarly purposes.

If you have any questions about the research study, please contact cessonline@nuffield.ox.ac.uk or Valentina Rotondi valentina.rotondi@sociology.ox.ac.uk

You could go to https://www.youtube.com/watch?v=nkPA3fb6K84\& feature=youtu.be to watch our Ethics Video. This research has been reviewed according to CESS IRB procedures for research involving human subjects.

I have read the information above. I affirm by hitting yes below that I understand what I have read above and still agree to participate in this study. 
Do you agree the above content?

\section{YES NO}

Display This Question:

If Ho letto le informazioni sopra. Cliccando su "si" dichiaro che ho compreso quello che ho letto so... $=\mathrm{Si}$

Sesso (Gender)

Maschio (Male)

Femmina (Female)

Età in anni compiuti (Age in completed years)

Stato civile (Marital status)

Celibe/nubile

Coniugato/a

Convivente

Separato/a o Divorziato/a

Vedovo/a

Titolo di studio (Education)

Dottorato di ricerca

Laurea magistrale/specialistica

Laurea Triennale

Diploma

Licenza media

Licenza Elementare

Nessun Titolo

Condizione lavorativa (Employment status)

Occupato

Disoccupato

Casalingo/a

Studente

Inabile al lavoro

Pensionato

Altro

Hai figli? (Do you have children?) 
$\mathrm{Si}$

No

Quant'è il 20\% di 100? (How much is 20\% of 100?)

Il 20\% di 100 è:

Non lo so

Su una scala da 0 a 10, quanto sei d'accordo con questa affermazione:

On a scale from 0 to 10 , how much do you agree with the following statement:

\begin{tabular}{|l|l|l|l|l|l|l|l|l|l|l|l|}
\hline & 0 & 1 & 2 & 3 & 4 & 5 & 6 & 7 & 8 & 9 & 10 \\
\hline
\end{tabular}

Anche i giovani sono a rischio di contrarre il Coronavirus. (Are younger people also at risk of contracting the Coronavirus?)

BEGINNING OF TREATMENT RANDOMIZATION. NOTICE THAT ONLY ONE OF THE TWO POSSIBILITIES IS SHOWN. IN THE ENGLISH TRANSLATION THE OMITTED SENTENCE IS INDICATED IN BOLD. NOTICE ALSO THAT, IF THE FIRST TREATMENT CONTAINS A REFERENCE TO THE SOURCE, THEN ALL OTHER SENTENCES CONTAIN THE REFERENCE TOO.

"Cosi come riportato dall'Istituto Superiore di Sanità, le persone anziane e quelle con condizioni mediche preesistenti sembrano essere soggette a manifestazioni cliniche più gravi a seguito di infezione da nuovo Coronavirus. Tuttavia, possono essere infettate dal virus (e contrarre malattie) persone di tutte le età"

"Le persone anziane e quelle con condizioni mediche preesistenti sembrano essere soggette a manifestazioni cliniche più gravi a seguito di infezione da nuovo Coronavirus. Tuttavia, possono essere infettate dal virus (e contrarre malattie) persone di tutte le età"

"As reported by the Italian Institute for Public Health, older people and those with pre-existing medical conditions seem to be subject to 
more serious clinical manifestations following infection with the new Coronavirus. However, people of all ages can be infected with the virus (and contract disease)"

Dopo aver letto l'informazione precedente, vorresti correggere la tua risposta?

- $\mathrm{Si}$

- No

Display This Question:

If Dopo aver letto l'informazione precedente, vorresti correggere la tua risposta? = Si

Su una scala da 0 a 10, quanto sei d'accordo con questa affermazione:

On a scale from 0 to 10, how much do you agree with the following statement:

\begin{tabular}{|l|l|l|l|l|l|l|l|l|l|l|}
0 & 1 & 2 & 3 & 4 & 5 & 6 & 7 & 8 & 9 & 10 \\
\hline
\end{tabular}

\begin{tabular}{|l|l|}
\hline Anche i giovani sono a rischio di contrarre \\
il Coronavirus. (Are younger people also at \\
risk of contracting the Coronavirus?)
\end{tabular}

$\mathrm{Su}$ una scala da 0 a 10 , quanto ritieni che:

On a scale from 0 to 10, how much do you think that:

\begin{tabular}{|l|l|l|l|l|l|l|l|l|l|l|}
0 & 1 & 2 & 3 & 4 & 5 & 6 & 7 & 8 & 9 & 10 \\
\hline
\end{tabular}

Gli antibiotici siano utili per prevenire l'infezione da nuovo Coronavirus

(Antibiotics are helpful in preventing the new Coronavirus infection) 
"Gli esperti del Ministero della Salute dichiarano che: gli antibiotici non sono efficaci contro i virus, ma funzionano solo contro le infezioni batteriche"

"Gli antibiotici non sono efficaci contro i virus, ma funzionano solo contro le infezioni batteriche"

"Ministry of Health experts say: antibiotics are not effective against viruses, but only work against bacterial infections"

Dopo aver letto l'informazione precedente, vorresti correggere la tua risposta? (Given the previous information, do you want to correct your answer?)

- $\mathrm{Si}$

- $\mathrm{No}$

Display This Question:

If Dopo aver letto l'informazione precedente, vorresti correggere la tua risposta? = Si

Su una scala da 0 a 10, quanto ritieni che:

On a scale from 0 to 10, how much do you think that:

\begin{tabular}{|l|l|l|l|l|l|l|l|l|l|l|}
0 & 1 & 2 & 3 & 4 & 5 & 6 & 7 & 8 & 9 & 10 \\
\hline
\end{tabular}

Gli antibiotici siano utili per prevenire l'infezione da nuovo Coronavirus (Antibiotics are helpful in preventing the new Coronavirus infection)

Su una scala da 0 a 10, quanto ritieni che:

On a scale from 0 to 10, how much do you think that: 


\begin{tabular}{|l|l|l|l|l|l|l|l|l|l|l|}
0 & 1 & 2 & 3 & 4 & 5 & 6 & 7 & 8 & 9 & 10 \\
\hline
\end{tabular}

Sia sicuro ricevere pacchi dalla Cina o da altri paesi dove il virus è stato identificato (It is safe to receive parcels from China or other countries where the virus has been identified)

"L'Organizzazione Mondiale della Sanità (OMS) ha dichiarato che le persone che ricevono pacchi non sono a rischio di contrarre il nuovo Coronavirus, perché non è in grado di sopravvivere a lungo sulle superfici."

"Le persone che ricevono pacchi non sono a rischio di contrarre il nuovo Coronavirus, perché non è in grado di sopravvivere a lungo sulle superfici."

"The World Health Organization declared that people who receive parcels are not at risk of contracting the new Coronavirus because the virus does not survive on surfaces for long."

Dopo aver letto l'informazione precedente, vorresti correggere la tua risposta?

- $\mathrm{Si}$

- No

Display This Question:

If Dopo aver letto l'informazione precedente, vorresti correggere la tua risposta? = Si 
Su una scala da 0 a 10, quanto ritieni che:

On a scale from 0 to 10, how much do you think that:

\begin{tabular}{|l|l|l|l|l|l|l|l|l|l|l|}
0 & 1 & 2 & 3 & 4 & 5 & 6 & 7 & 8 & 9 & 10 \\
\hline
\end{tabular}

Sia sicuro ricevere pacchi dalla Cina o da altri paesi dove il virus è stato identificato (It is safe to receive parcels from China or other countries where the virus has been identified)

Il lavaggio delle mani serva veramente per prevenire l'infezione da Coronavirus (Washing hands is really useful in preventing the Coronavirus infection)

Su una scala da 0 a 10, quanto pensi che:

On a scale from 0 to 10 , how much do you think that:

\begin{tabular}{|l|l|l|l|l|l|l|l|l|l|l|l|}
\hline & 0 & 1 & 2 & 3 & 4 & 5 & 6 & 7 & 8 & 9 & 10 \\
\hline
\end{tabular}

"Secondo gli esperti dell'Istituto Superiore di Sanità, il lavaggio e la disinfezione delle mani sono la chiave per prevenire l'infezione. Bisogna lavarsi le mani spesso e accuratamente con acqua e sapone per ameno 20 secondi (meglio 40-60). Se non sono disponibili acqua e sapone, è possibile utilizzare anche un disinfettante per mani a base di alcol con almeno il $60 \%$ di alcol. Il virus entra nel corpo attraverso gli occhi, il naso e la bocca, quindi evita di toccarli con le mani non lavate."

"Il lavaggio e la disinfezione delle mani sono la chiave per prevenire l'infezione. Bisogna lavarsi le mani spesso e accuratamente con acqua e sapone per ameno 20 secondi (meglio 40-60). Se non sono disponibili acqua e sapone, è possibile utilizzare anche un disinfettante per mani 
a base di alcol con almeno il $60 \%$ di alcol. Il virus entra nel corpo attraverso gli occhi, il naso e la bocca, quindi evita di toccarli con le mani non lavate"

"According to the National Institute for Public Health experts hand washing and disinfection are the key to preventing infection. You must wash your hands often and thoroughly with soap and water for at least 20 seconds (better 40-60). If soap and water are not available, an alcohol-based hand sanitizer with at least $60 \%$ alcohol can also be used. The virus enters the body through the eyes, nose and mouth, so avoid touching them with unwashed hands."

Dopo aver letto l'informazione precedente, vorresti correggere la tua risposta?

\section{- $\mathrm{Si}$}

- No

Display This Question:

If Dopo aver letto l'informazione precedente, vorresti correggere la tua risposta? = Si

Su una scala da 0 a 10, quanto pensi che:

On a scale from 0 to 10, how much do you think that:

\begin{tabular}{l|l|l|l|l|l|l|l|}
0 & 1 & 2 & 3 & 4 & 5 & 6 & 7 \\
\hline
\end{tabular}

\begin{tabular}{l|l|l|l|}
\hline & 8 & 9 & 10 \\
\hline
\end{tabular}

Il lavaggio delle mani serva veramente per prevenire l'infezione da Coronavirus (Washing hands is really useful in preventing the Coronavirus infection) 
Su una scala da 0 a 100, quanto ti fidi: On a scale from 0 to 100, how much do you trust:

\begin{tabular}{|l|l|l|l|l|l|l|l|l|l|l|}
0 & 10 & 20 & 30 & 40 & 50 & 60 & 70 & 80 & 90 & 100 \\
\hline
\end{tabular}

\begin{tabular}{|l|l|}
\hline Della scienza (Science) & \\
\hline $\begin{array}{l}\text { Del governo nazionale (the National Gov- } \\
\text { ernment) }\end{array}$ & \\
\hline $\begin{array}{l}\text { Del governo regionale (the Regional Gov- } \\
\text { ernment) }\end{array}$ & \\
\hline $\begin{array}{l}\text { Dell'Istituto Superiore di Sanità (The Na- } \\
\text { tional Institute for Public Health) }\end{array}$ & \\
\hline
\end{tabular}



virus: In order to reduce the spread of the virus, how it is important in your opinion to:

\begin{tabular}{|l|l|l|l|l|l|l|l|l|l|l|l|}
\hline & 0 & 1 & 2 & 3 & 4 & 5 & 6 & 7 & 8 & 9 & 10 \\
\hline
\end{tabular}

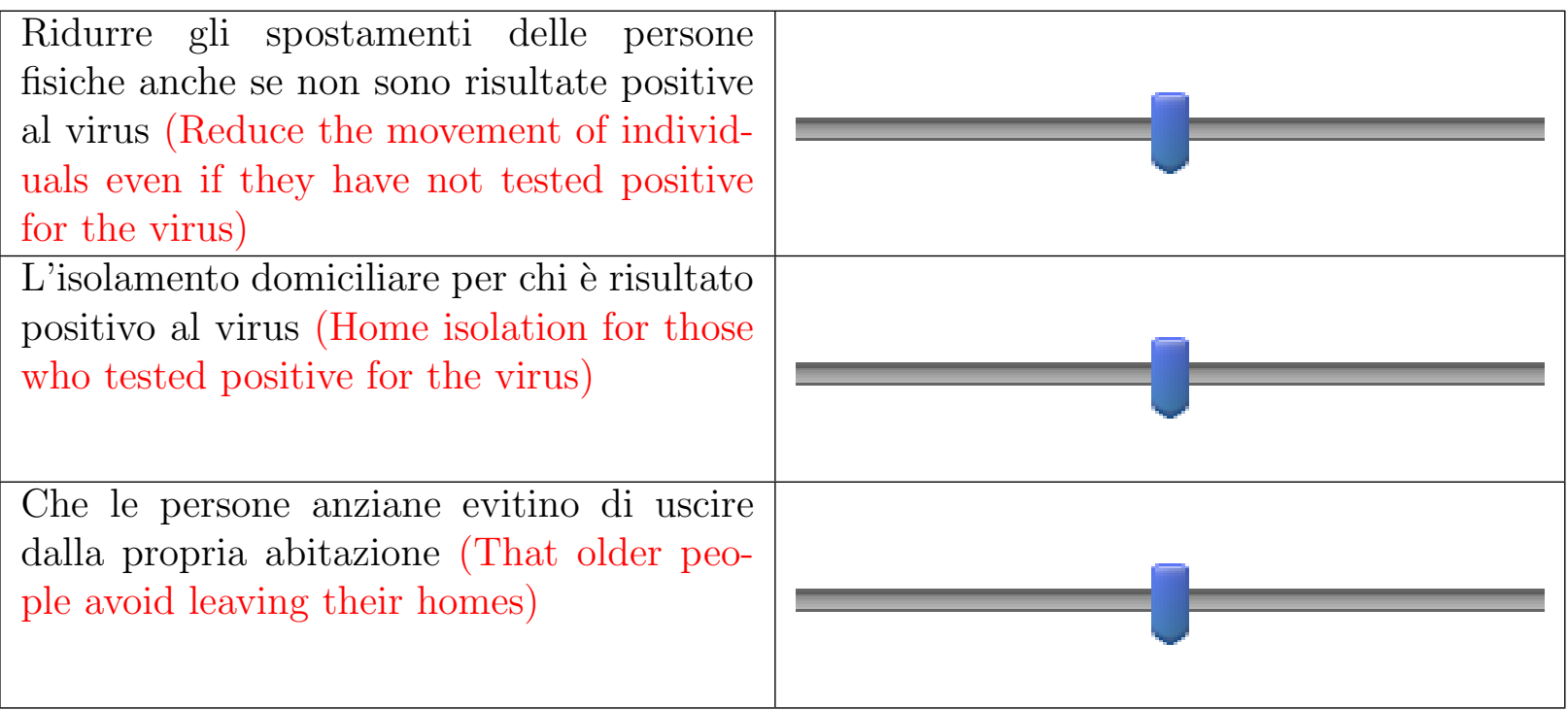


Quando si discutono questioni politiche la gente di solito parla di sinistra e destra. In generale, come ti classificheresti lungo questa scala?

In political matters, people talk of "the left" and "the right." How would you place your views on this scale, generally speaking?

\begin{tabular}{l|l} 
Sinistra & Destra
\end{tabular}

\begin{tabular}{|l|l|l|l|l|l|l|l|l|l|l|}
0 & 1 & 2 & 3 & 4 & 5 & 6 & 7 & 8 & 9 & 10 \\
\hline
\end{tabular}

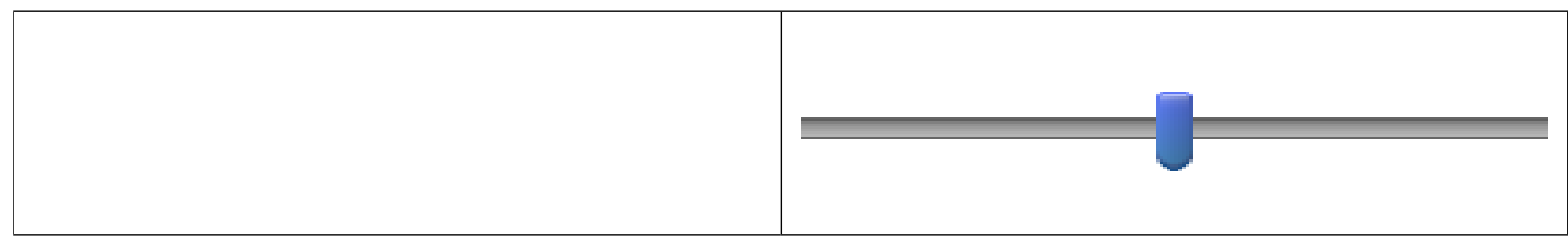

Indica il codice di avviamento postale del comune in cui risiedi abitualmente (CAP) (ZIP code)

\section{INFORMATION FOR PAYMENT}

Le informazioni che ti abbiamo dato sono diffuse dal Ministero della Salute e dall'Istituto Superiore di Sanità. Ti consigliamo di consultare le sezioni relative al nuovo Coronavirus del sito del Ministero della Salute (http://www.salute.gov.it/portale/malattieInfettive/homeMalattieInfett jsp) e del sito dell'Istituto Superiore di Sanità (https : //www . epicentro . iss.it/Coronavirus/faq)

These information are retrived from the Ministry of Health and from the Institute for Public Health. We advise to see the section relative to Coronavirus on their websites (http://www.salute.gov.it/portale/ malattieInfettive/homeMalattieInfettive.jsp and https://www . epicentro.iss.it/Coronavirus/faq) 
Table S1: Summary statistics

\begin{tabular}{lcccc}
\hline \hline \multicolumn{1}{c}{ Variable } & Mean & Std. Dev. & Min. & Max. \\
\hline \# of mentions: scientists & 0.009 & 0.114 & 0 & 3 \\
\# of mentions: politicians & 0.069 & 0.358 & 0 & 8 \\
\# of mentions: media & 0.042 & 0.243 & 0 & 4 \\
\# of mentions: authorities & 0.024 & 0.172 & 0 & 4 \\
\# of mentions: health authorities & 0.013 & 0.119 & 0 & 2 \\
\# of mentions: other & 0.024 & 0.176 & 0 & 3 \\
Weighted cases count (unif.) & 0.477 & 0.275 & 0 & 0.954 \\
$\mathrm{~N}$ & \multicolumn{2}{c}{10336} \\
\hline
\end{tabular}

Table S2: Summary statistics: Retweets

\begin{tabular}{lcccc}
\hline \hline Variable & Mean & Std. Dev. & Min. & Max. \\
\hline Authorities & 0.092 & 0.289 & 0 & 1 \\
Health authorities & 0.081 & 0.272 & 0 & 1 \\
Journalists & 0.055 & 0.228 & 0 & 1 \\
Media & 0.015 & 0.12 & 0 & 1 \\
Other & 0.092 & 0.289 & 0 & 1 \\
Politicians & 0.299 & 0.458 & 0 & 1 \\
Scientists & 0.257 & 0.437 & 0 & 1 \\
\multicolumn{1}{c}{ N } & 37024 & \\
\hline
\end{tabular}




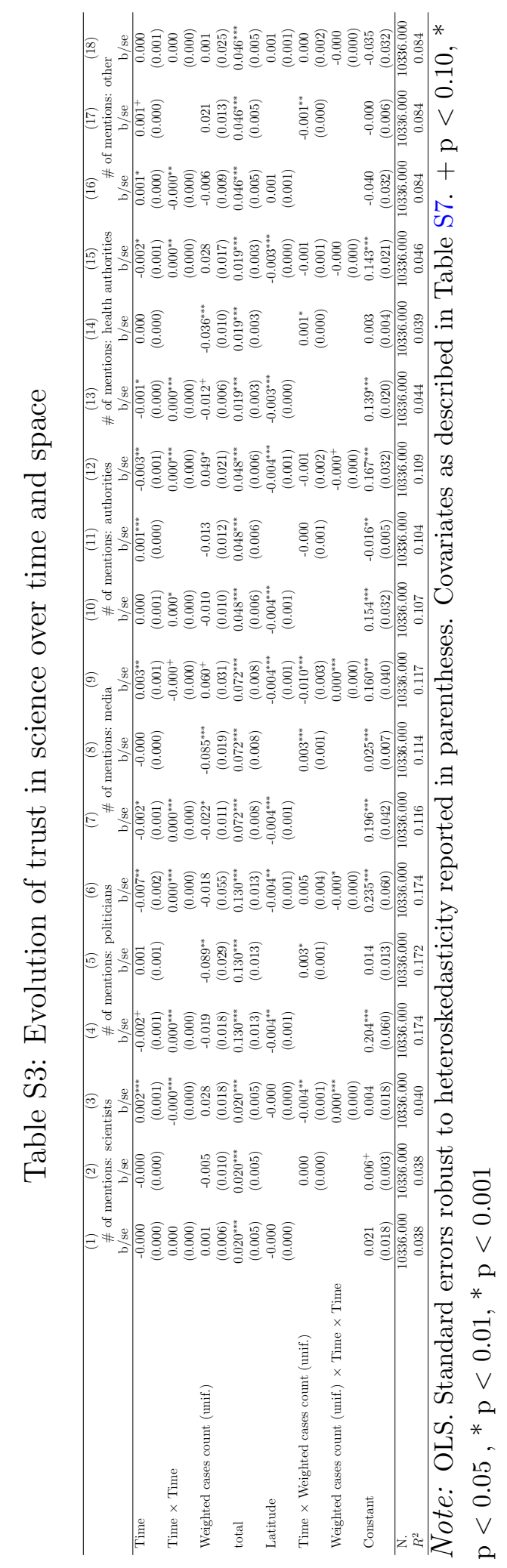


Figure S2: Distribution of Twitter samples over time
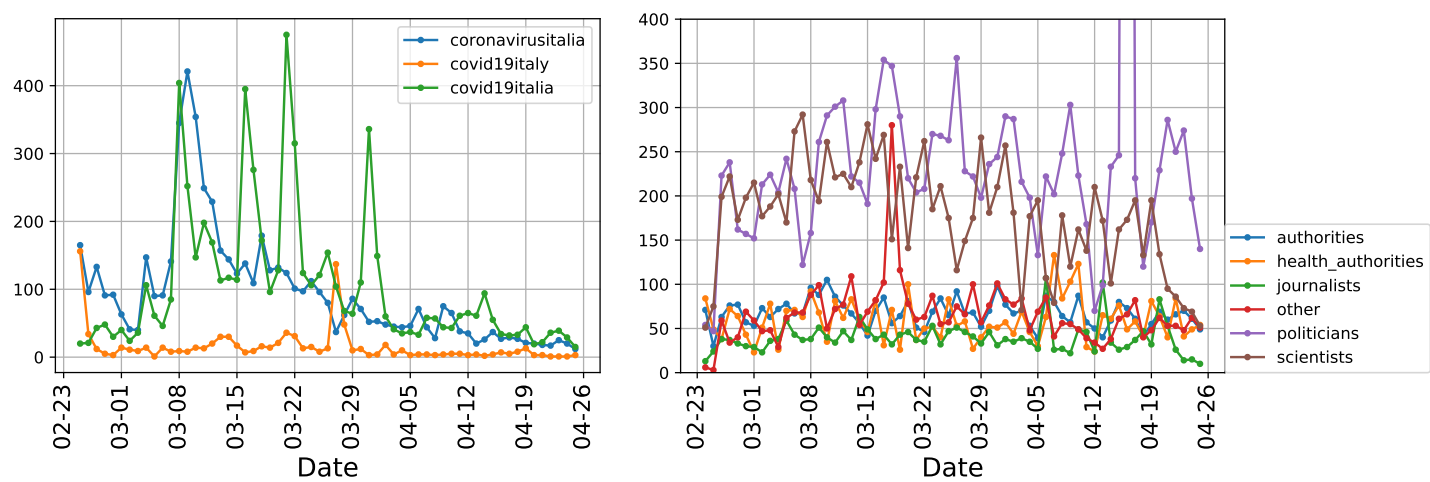

Note: distribution over time of tweets used to analyze mentions (left) and retweets (right). Not shown in right panel: outlier value of 2735 for category "politicians" on April 16, entirely attributable to a single account.

Table S4: Evolution of retweets over time

\begin{tabular}{lcccccc}
\hline & $(1)$ & $(2)$ & $(3)$ & $(4)$ & $(5)$ & $(6)$ \\
& $\begin{array}{c}\text { Scientists } \\
\mathrm{b} / \mathrm{se}\end{array}$ & $\begin{array}{c}\text { Authorities } \\
\mathrm{b} / \mathrm{se}\end{array}$ & $\begin{array}{c}\text { Health Authorities } \\
\mathrm{b} / \mathrm{se}\end{array}$ & $\begin{array}{c}\text { Media } \\
\mathrm{b} / \mathrm{se}\end{array}$ & $\begin{array}{c}\text { Politicians } \\
\mathrm{b} / \mathrm{se}\end{array}$ & $\begin{array}{c}\text { Other } \\
\mathrm{b} / \mathrm{se}\end{array}$ \\
\hline time & $1.460^{* *}$ & $4.836^{* * *}$ & $32.315^{* * *}$ & -0.041 & -0.712 & 2.184 \\
& $(0.561)$ & $(1.004)$ & $(7.730)$ & $(0.188)$ & $(0.631)$ & $(1.427)$ \\
time $\times$ time & $-0.037^{* * *}$ & $-0.096^{* * *}$ & $-0.691^{* * *}$ & 0.001 & 0.020 & -0.025 \\
& $(0.011)$ & $(0.021)$ & $(0.157)$ & $(0.002)$ & $(0.013)$ & $(0.027)$ \\
total & 0.000 & 0.000 & $0.003^{*}$ & 0.000 & 0.000 & -0.000 \\
& $(0.000)$ & $(0.000)$ & $(0.001)$ & $(0.000)$ & $(0.000)$ & $(0.000)$ \\
Constant & $26.452^{* * *}$ & $20.380^{*}$ & -95.672 & 2.248 & $70.725^{* * *}$ & $24.321^{+}$ \\
& $(6.826)$ & $(9.714)$ & $(89.673)$ & $(3.691)$ & $(7.230)$ & $(13.854)$ \\
\hline N. & 8606.000 & 3409.000 & 2676.000 & 537.000 & 11058.000 & 3412.000 \\
$R^{2}$ & 0.002 & 0.004 & 0.012 & 0.004 & 0.001 & 0.001 \\
\hline
\end{tabular}

OLS. Standard errors robust to heteroskedasticity reported in parentheses. Covariates as described in Table S7. $+\mathrm{p}<0.10,{ }^{*} \mathrm{p}<0.05,{ }^{*} \mathrm{p}<0.01,{ }^{*} \mathrm{p}<0.001$ 


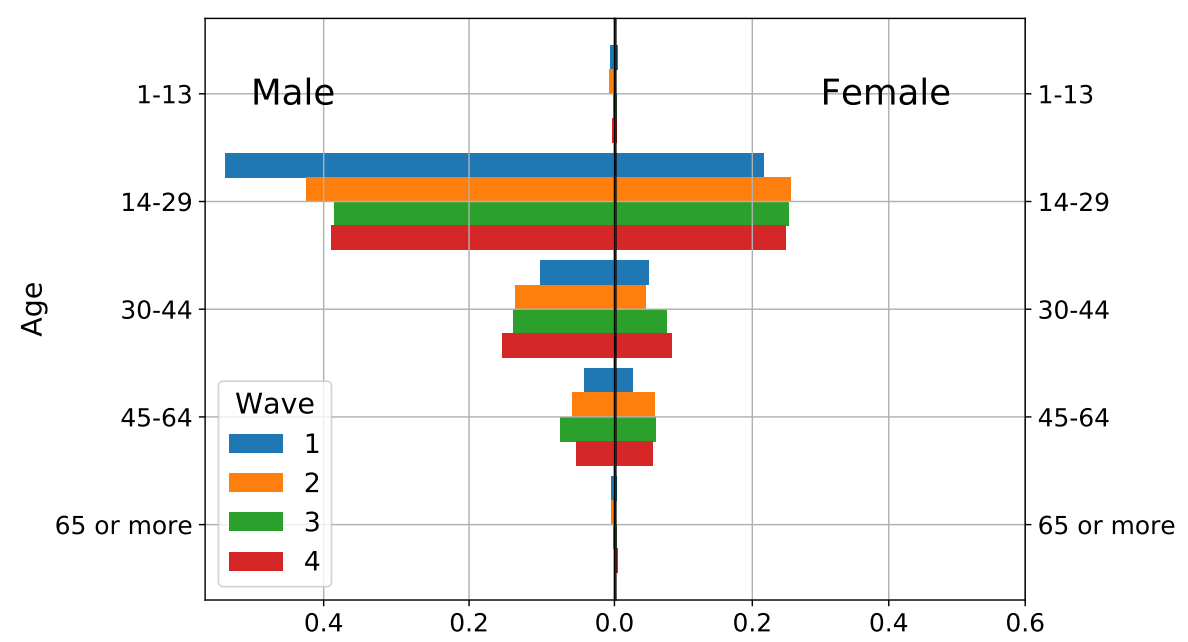

Figure S3: Distribution of Telegram respondents across age ranges and genders

Figure 3 shows the unbalanced analysis of changes of interest in different categories of information sources across waves; the equivalent balanced analysis is displayed in Figure S5. Both figures clearly show that interest in all sources of information is increasing from wave to wave except for the category "famous persons from the show business and sports", and that these changes are statistically significant. Minor differences between the unbalanced and balanced version are likely due to two main phenomena. On one hand, the sample changed significantly across waves (in turn a consequence of the huge increase in the popularity of the Telegram channel) On the other hand, it was not always possible to track participants across waves: in particular, in wave 4 participants filled the survey outside the Telegram app and had the possibility to not being matched to their responses in previous waves.

The fourth and last wave of the Telegram survey included a simplified version of the survey experiment: subjects were randomly sent (via personalized links) to one out of two versions of the survey. In both versions of the survey, respondents were asked to answer the question "Are younger people also at risk of contracting the Coronavirus?" by picking an answer from 0 to 10 after reading the text of the ISS information about all age categories being at risk: but while in one version ISS was cited as source, in the other version no source was provided.

In both versions of the survey, 10 was the most chosen option, but it was chosen more frequently $(77.5 \%$ vs. $75.6 \%)$ when the source of the state- 


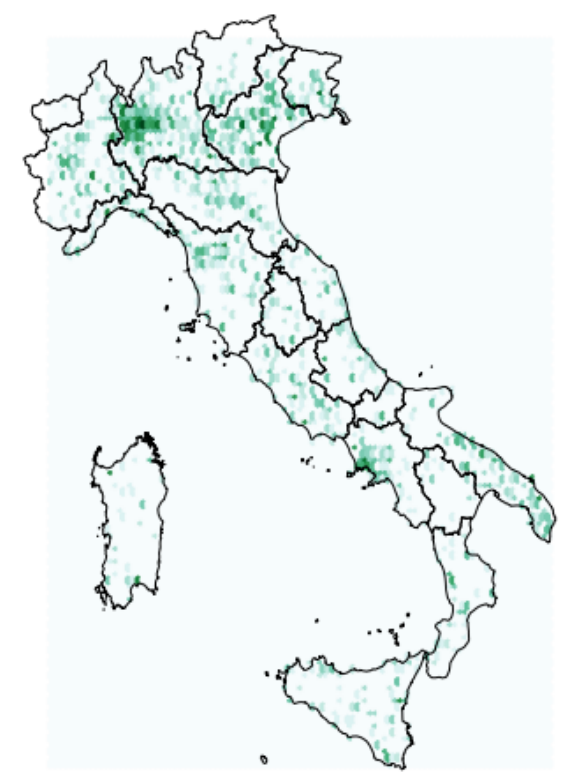

Figure S4: Geographic distribution of Telegram respondents

Figure S5: Longitudinal evidence from Telegram survey - balanced samples

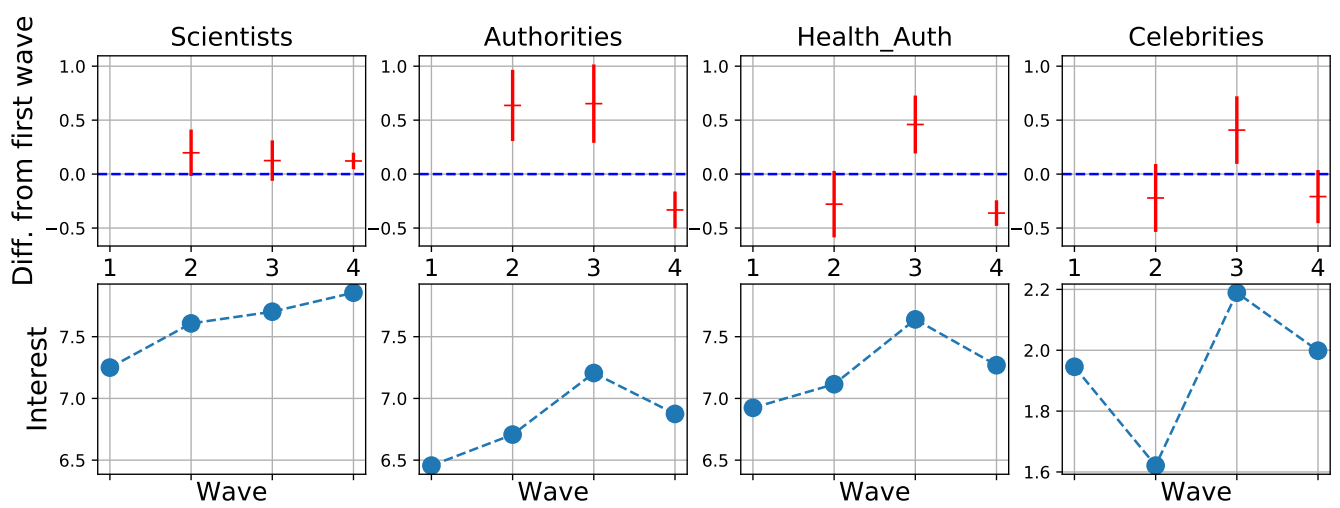

Note: equivalent of Figure 3 reducing to recurring respondents. Top: differences across waves computed on subsamples of participants who were tracked across the two consecutive waves. Bottom: averages across waves computer for all participants tracked across any two consecutive waves. 
Table S5: Evolution of willingness to receive information from different sources over time

\begin{tabular}{lccccc}
\hline & Scientists & Authorities & HealthAuth & Celebrities & experts \\
\hline Intercept & $6.807^{* * *}$ & $6.280^{* * *}$ & $6.647^{* * *}$ & $3.105^{* * *}$ & $2.034^{* * *}$ \\
& $(0.256)$ & $(0.251)$ & $(0.246)$ & $(0.327)$ & $(0.237)$ \\
Wave 2 & 0.241 & 0.230 & 0.449 & $-0.911^{* *}$ & $0.685^{* *}$ \\
& $(0.401)$ & $(0.413)$ & $(0.309)$ & $(0.388)$ & $(0.280)$ \\
Wave 3 & $0.856^{* * *}$ & 0.450 & $0.911^{* * *}$ & -0.340 & $0.829^{* *}$ \\
& $(0.272)$ & $(0.469)$ & $(0.264)$ & $(0.456)$ & $(0.415)$ \\
Wave 4 & $0.817^{* * *}$ & $0.767^{* * *}$ & $0.645^{* *}$ & $-0.908^{* *}$ & $0.801^{* * *}$ \\
& $(0.277)$ & $(0.288)$ & $(0.273)$ & $(0.357)$ & $(0.254)$ \\
\hline Observations & 8872 & 8872 & 8872 & 8872 & 8872 \\
R2 & 0.060 & 0.029 & 0.041 & 0.033 & 0.046 \\
\hline \hline
\end{tabular}

Note: OLS. Robust standard errors reported in parenthesis. "Experts" is defined as the difference between the average reply to scientists and health authorities and the average interest to authorities and celebrities. See section M5 for a description of the model and section S2.1 for a description of the exact wording of the questions and of the sampling strategy.

Table S6: Evolution of willingness to receive information from different sources over time and space

\begin{tabular}{lccccc}
\hline & Scientists & Authorities & HealthAuth & Celebrities & experts \\
\hline Intercept & $9.729^{* * *}$ & $5.727^{*}$ & $7.409^{* * *}$ & 4.565 & $3.422^{*}$ \\
& $(2.125)$ & $(3.285)$ & $(2.187)$ & $(3.163)$ & $(1.860)$ \\
lat & -0.062 & 0.015 & -0.007 & -0.052 & -0.016 \\
& $(0.052)$ & $(0.079)$ & $(0.054)$ & $(0.073)$ & $(0.042)$ \\
wave & -0.039 & 0.058 & -0.008 & 0.291 & -0.198 \\
& $(0.089)$ & $(0.316)$ & $(0.261)$ & $(0.211)$ & $(0.131)$ \\
wcc & $0.889^{* *}$ & 0.409 & 0.173 & -0.837 & 0.745 \\
& $(0.390)$ & $(1.145)$ & $(0.890)$ & $(0.719)$ & $(0.488)$ \\
\hline Observations & 3592 & 3592 & 3592 & 3592 & 3592 \\
R2 & 0.024 & 0.010 & 0.001 & 0.020 & 0.010 \\
\hline \hline
\end{tabular}

Note: OLS. Robust standard errors reported in parenthesis. "Experts" is defined as the difference between the average reply to scientists and health authorities and the average interest to authorities and celebrities. Weighted cases count $(w c c)$ is the percentile of the number of cases per province at date of interview, weighted by the inverse of the distance from each province. See section M5 for a description of the model and section S2.1 for a description of the exact wording of the questions and of the sampling strategy. 
Figure S6: Frequency of replies in Telegram experiment: difference across treatment

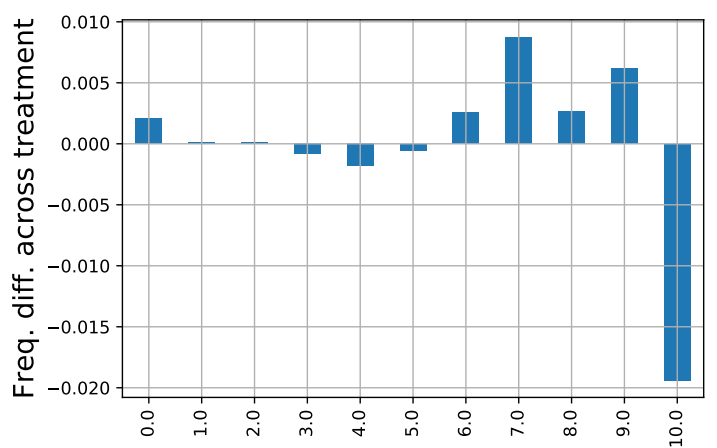

Are younger people also at risk of contracting the coronavirus?

ment was not mentioned, consistently with results from the Facebook Ad experiment: Figure S6 shows that most of the difference is explained by respondents who chose a number between 6 and 9, rather than 19. However, when regressing the choice of 10 as response over the treatment selection (controlling for standard demographics - age, gender, level of studies), we obtain that the difference is only marginally significant $(p=0.10)$.

\section{S3.3 Facebook}

\section{S3.4 Sampling Strategy}

We administered to Facebook users residing in 15 provinces in Lombardy ${ }^{14}$ and Veneto ${ }^{15}$, two regions located in northern Italy, a pre-registered survey and a survey experiment. We specifically targeted two early outbreak areas which were quarantined since February 21st (including 10 municipalities in Lombardy and 1 in Veneto), as well as municipalities bordering with these initial outbreak municipalities for a total of 66 municipalities (46 in Lombardy and 20 in Veneto). We then separately targeted an area in the province of Bergamo (BG) which has been severely affected by the epidemic (Buonanno et al., 2020) and the municipalities bordering this area for a total of 32 municipalities. Figure S7 provides a visual representation of those early outbreak municipalities. For a description of the early outbreak Italian areas and a discussion on the differential policies implemented by the Italian government in each of them see Rotondi et al. (2020). The geographical

\footnotetext{
${ }^{14}$ Lodi (LO), Cremona (CR), Mantova (MN), Brescia (BS), Bergamo (BG), Lecco (LC), Monza and Brianza (MB), Milano (MI), and Pavia (PV).

${ }^{15}$ Verona (VR), Vicenza (VI), Treviso (TV), Venezia (VE), Rovigo (RO), and Padova (PD).
} 
targeting worked well. Nevertheless, we unwittingly recruited a sample of respondents even outside the initially targeted areas, as shown in Figure S8.

Participants in the online survey were offered a modest payment.

Figure S7: Sampling strategy: Regions in Northern Italy

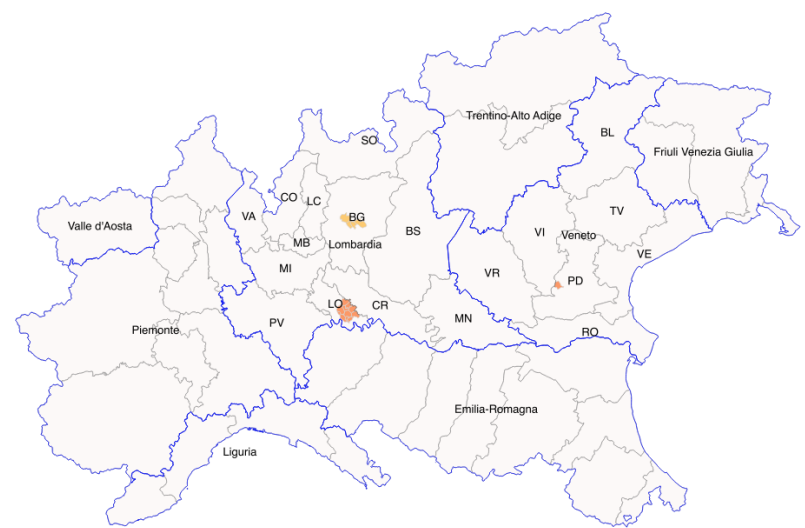


Figure S8: Actual responses: Italy

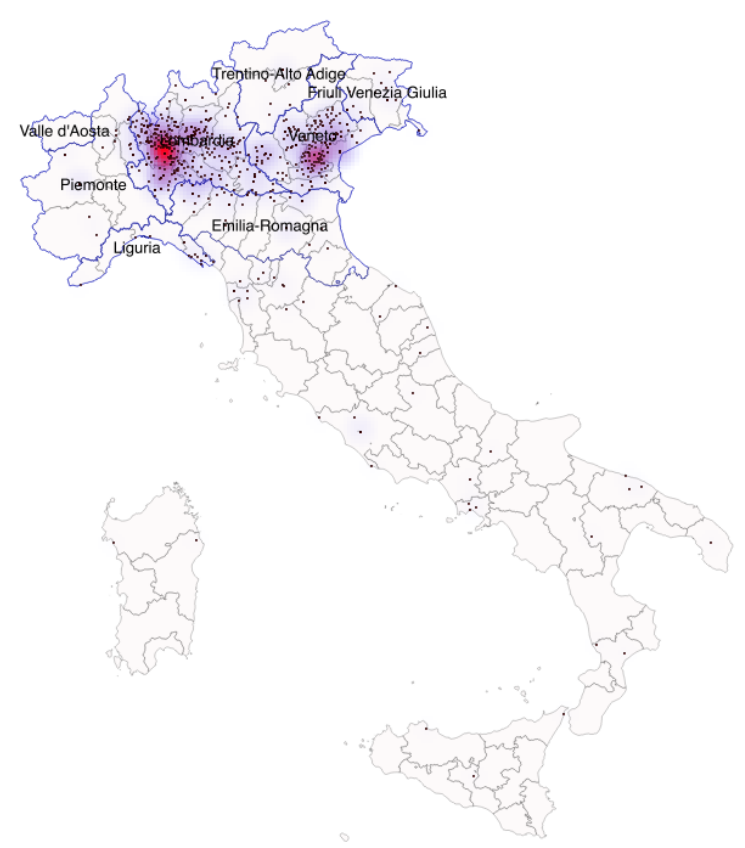

Note: Every point corresponds to a respondent. Data have been geolocalized based on respondents' ZIP codes. The brighter the red the higher the number of respondents.

Figure S9: Weighted cases count (wcc) of respondents

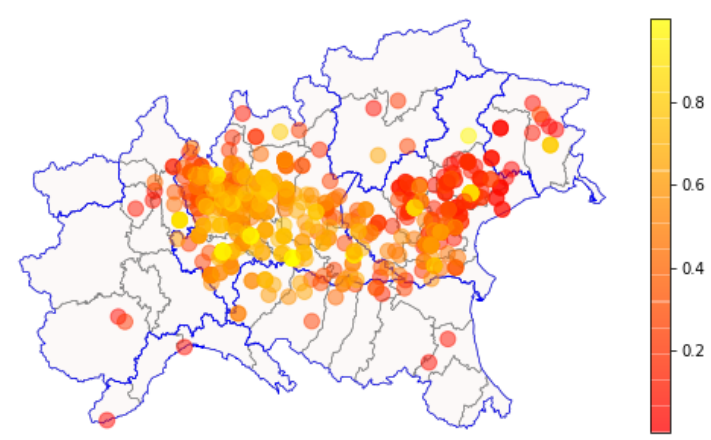

Note: Every point corresponds to a respondent. Data have been geolocalized based on respondents' ZIP codes. Colors corresponds to percentiles in the wcc distribution. 
Figure S10: Number of cases tested positive for COVID-19 by province in Lombardy and Veneto as for March, 172020

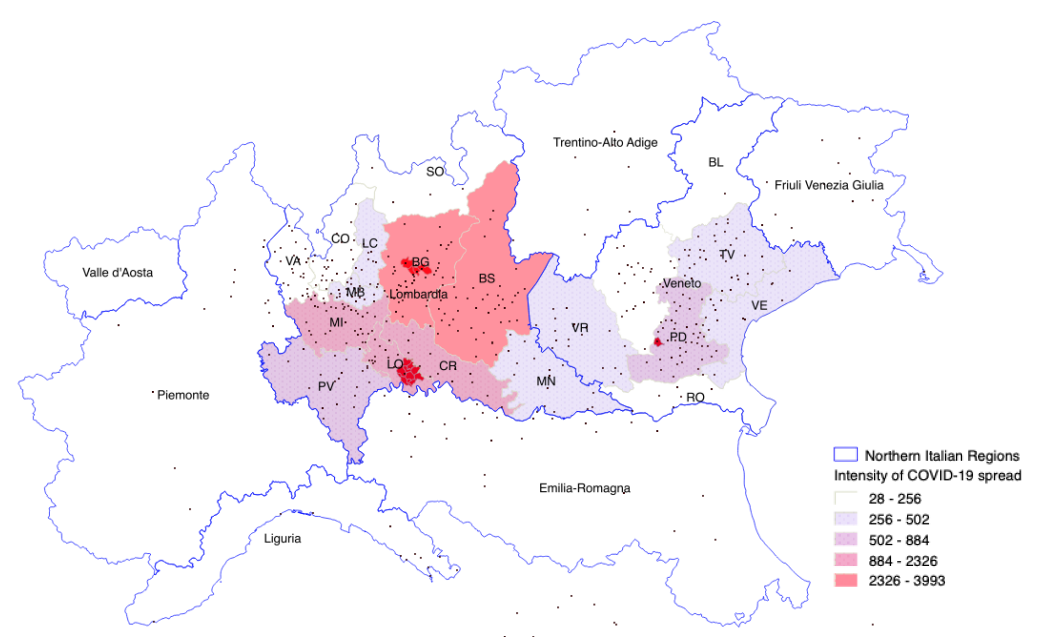

Note: Every point corresponds to a respondent. Data have been geolocalized based on respondents' ZIP codes. Province-level data on cases for Lombardy and Veneto tested positive for COVID-19 are available at the following link: https://github.com/pcm-dpc/ COVID-19 
Table S7: Summary statistics

\begin{tabular}{|c|c|c|c|c|c|}
\hline Variable & Mean & Std. Dev. & Min. & Max. & $\overline{\mathbf{N}}$ \\
\hline \multicolumn{6}{|l|}{ Outcomes } \\
\hline Younger people are also at risk of contracting the Coronavirus & 9.194 & 1.52 & 1 & 10 & 994 \\
\hline Antibiotics are helpful in preventing the new Coronavirus infection & 1.51 & 2.262 & 0 & 10 & 810 \\
\hline It is safe to receive parcels from China & 8.528 & 2.114 & 0 & 10 & 984 \\
\hline Washing hands is really useful in preventing the Coronavirus infection & 9.282 & 1.23 & 1 & 10 & 990 \\
\hline Wrong: Youths & 0.321 & 0.467 & 0 & 1 & 994 \\
\hline Wrong: Antibiotics & 0.469 & 0.499 & 0 & 1 & 810 \\
\hline Wrong: Parcels & 0.514 & 0.5 & 0 & 1 & 984 \\
\hline Wrong: Hands & 0.36 & 0.48 & 0 & 1 & 990 \\
\hline Social distancing: non-positive & 9.231 & 1.509 & 0 & 10 & 984 \\
\hline Isolation: positive & 9.871 & 0.676 & 0 & 10 & 986 \\
\hline Social distancing: elderly & 9.595 & 1.154 & 0 & 10 & 984 \\
\hline \multicolumn{6}{|l|}{ Trust } \\
\hline Trust: National Inst. Pub. Health & 85.933 & 16.299 & 0 & 100 & 985 \\
\hline Trust: regional government & 62.686 & 24.3 & 0 & 100 & 980 \\
\hline Trust: national government & 63.562 & 23.119 & 0 & 100 & 977 \\
\hline Trust: science & 93.36 & 10.378 & 12 & 100 & 987 \\
\hline \multicolumn{6}{|l|}{ Trust: Robustness } \\
\hline Trust science (avg) & 89.704 & 11.629 & 20.5 & 100 & 986 \\
\hline Trust politicians (avg) & 63.13 & 20.839 & 0 & 100 & 978 \\
\hline \multicolumn{6}{|l|}{ Information: Expert } \\
\hline Info: experts & 0.494 & 0.5 & 0 & 1 & 995 \\
\hline \multicolumn{6}{|l|}{ Willing to update (if wrong) } \\
\hline Willing to update: Youths & 0.129 & 0.335 & 0 & 1319 & \\
\hline Willing to update: Antibiotics & 0.342 & 0.475 & 0 & 1 & 380 \\
\hline Willing to update: Parcels & 0.168 & 0.374 & 0 & 1 & 507 \\
\hline Willing to update: Hands & 0.09 & 0.286 & 0 & 1 & 357 \\
\hline \multicolumn{6}{|l|}{ Covariates } \\
\hline Single & 0.602 & 0.49 & 0 & 1 & 994 \\
\hline Married & 0.2 & 0.4 & 0 & 1 & 994 \\
\hline Cohabitation & 0.148 & 0.355 & 0 & 1 & 994 \\
\hline Divorced & 0.047 & 0.212 & 0 & 1 & 994 \\
\hline Widow & 0.003 & 0.055 & 0 & 1 & 994 \\
\hline Secondary & 0.318 & 0.466 & 0 & 1 & 994 \\
\hline PHD & 0.046 & 0.21 & 0 & 1 & 994 \\
\hline Bachelor & 0.248 & 0.432 & 0 & 1 & 994 \\
\hline Master & 0.359 & 0.48 & 0 & 1 & 994 \\
\hline Lower Secondary & 0.028 & 0.166 & 0 & 1 & 994 \\
\hline Other & 0.032 & 0.177 & 0 & 1 & 994 \\
\hline Housewife & 0.019 & 0.137 & 0 & 1 & 994 \\
\hline Unemployed & 0.133 & 0.34 & 0 & 1 & 994 \\
\hline Employed & 0.5 & 0.5 & 0 & 1 & 994 \\
\hline Retired & 0.019 & 0.137 & 0 & 1 & 994 \\
\hline Student & 0.297 & 0.457 & 0 & 1 & 994 \\
\hline Math skills & 0.965 & 0.183 & 0 & 1 & 979 \\
\hline Has children & 0.225 & 0.418 & 0 & 1 & 994 \\
\hline Gender & 0.345 & 0.476 & 0 & 1 & 992 \\
\hline Age & 32.87 & 11.616 & 18 & 74 & 993 \\
\hline Distance from outbreak areas & 128.407 & 95.257 & 69.531 & 932.398 & 994 \\
\hline Outbreak areas & 0.077 & 0.267 & 0 & 1 & 994 \\
\hline
\end{tabular}


Table S8: Randomization

\begin{tabular}{|c|c|c|}
\hline & $\begin{array}{c}(1) \\
\text { Info: experts } \\
\text { b/se }\end{array}$ & $\begin{array}{c}(2) \\
\text { Info: experts } \\
\text { b/se }\end{array}$ \\
\hline Trust: science & $\begin{array}{c}0.000 \\
(0.002)\end{array}$ & $\begin{array}{l}-0.000 \\
(0.002)\end{array}$ \\
\hline Trust: national government & $\begin{array}{c}0.001 \\
(0.001)\end{array}$ & $\begin{array}{c}0.001 \\
(0.001)\end{array}$ \\
\hline Trust: regional government & $\begin{array}{c}0.000 \\
(0.001)\end{array}$ & $\begin{array}{c}0.001 \\
(0.001)\end{array}$ \\
\hline Trust: National Inst. Pub. Health & $\begin{array}{c}0.000 \\
(0.001)\end{array}$ & $\begin{array}{l}0.000 \\
(0.001)\end{array}$ \\
\hline Gender & & $\begin{array}{l}0.014 \\
(0.036)\end{array}$ \\
\hline Age & & $\begin{array}{l}-0.001 \\
(0.002)\end{array}$ \\
\hline Secondary & & $\begin{array}{l}-0.053 \\
(0.115)\end{array}$ \\
\hline Bachelor & & $\begin{array}{l}-0.012 \\
(0.117)\end{array}$ \\
\hline Master and Higher & & $\begin{array}{l}-0.023 \\
(0.116)\end{array}$ \\
\hline Married & & $\begin{array}{l}-0.071 \\
(0.067)\end{array}$ \\
\hline Cohabitation & & $\begin{array}{l}-0.010 \\
(0.053)\end{array}$ \\
\hline Divorced & & $\begin{array}{l}-0.052 \\
(0.093)\end{array}$ \\
\hline Widow & & $\begin{array}{l}0.260 \\
(0.252)\end{array}$ \\
\hline Has children & & $\begin{array}{c}0.030 \\
(0.059)\end{array}$ \\
\hline Housewife & & $\begin{array}{l}0.269^{*} \\
(0.135)\end{array}$ \\
\hline Other & & $\begin{array}{l}0.155 \\
(0.106)\end{array}$ \\
\hline Employed & & $\begin{array}{l}0.036 \\
(0.055)\end{array}$ \\
\hline Retired & & $\begin{array}{l}-0.088 \\
(0.144)\end{array}$ \\
\hline Student & & $\begin{array}{c}-0.010 \\
(0.060)\end{array}$ \\
\hline Math skills & & $\begin{array}{l}0.155^{+} \\
(0.085)\end{array}$ \\
\hline LR scale & & $\begin{array}{c}0.000 \\
(0.008)\end{array}$ \\
\hline Outbreak areas & & $\begin{array}{l}-0.085 \\
(0.068)\end{array}$ \\
\hline Lombardy & & $\begin{array}{l}0.006 \\
(0.054)\end{array}$ \\
\hline Veneto & & $\begin{array}{l}-0.020 \\
(0.057)\end{array}$ \\
\hline Latitude & & $\begin{array}{l}-0.009 \\
(0.024)\end{array}$ \\
\hline Constant & $\begin{array}{l}0.319^{*} \\
(0.150)\end{array}$ & $\begin{array}{c}0.702 \\
(1.077)\end{array}$ \\
\hline $\begin{array}{l}\text { N. } \\
R^{2}\end{array}$ & $\begin{array}{c}978 \\
0.007\end{array}$ & $\begin{array}{c}930 \\
0.023\end{array}$ \\
\hline
\end{tabular}

OLS. Robust standard errors reported in parentheses. Covariates as described in Table S7. $+\mathrm{p}<0.10,{ }^{*} \mathrm{p}<0.05,{ }^{*} \mathrm{p}<0.01,{ }^{*} \mathrm{p}<0.001$ 
Figure S11: Scatter plot matrix of trust measures

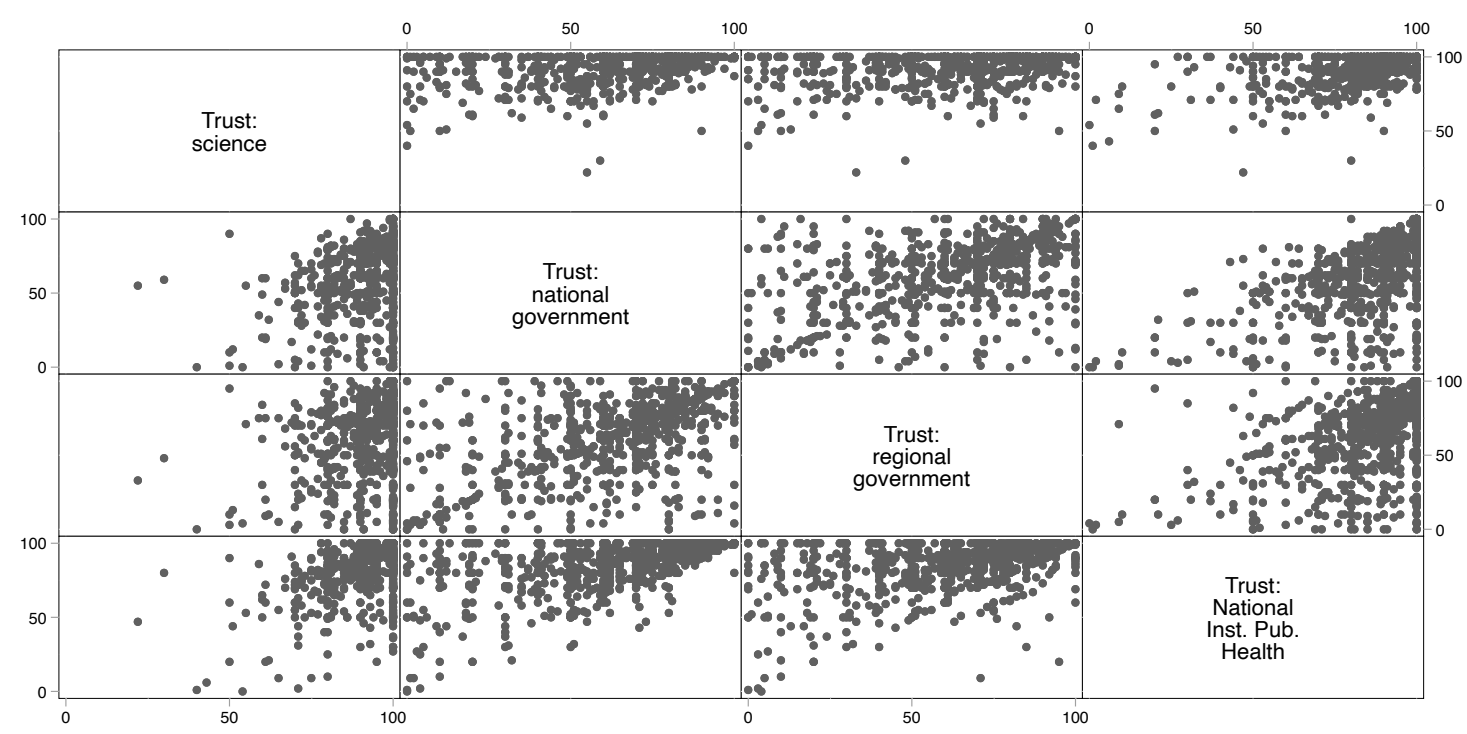

Table S9: Cross-correlation table between trust measures

\begin{tabular}{lcccc}
\hline \hline \multicolumn{1}{c}{ Variables } & Pub. Health & Reg. Gov. & Nat. Gov. & Science \\
\hline Trust: National Inst. Pub. Health & 1.0000 & & & \\
Trust: regional government & 0.4176 & 1.0000 & & \\
& $(0.0000)$ & & & \\
Trust: national government & 0.5510 & 0.5443 & 1.0000 & \\
& $(0.0000)$ & $(0.0000)$ & & \\
Trust: science & 0.5369 & 0.2247 & 0.3290 & 1.0000 \\
& $(0.0000)$ & $(0.0000)$ & $(0.0000)$ & \\
\hline \hline
\end{tabular}


Figure S12: Reception of public health messages on the importance of social distancing and the isolation of positive cases by Italian respondents (weighted)

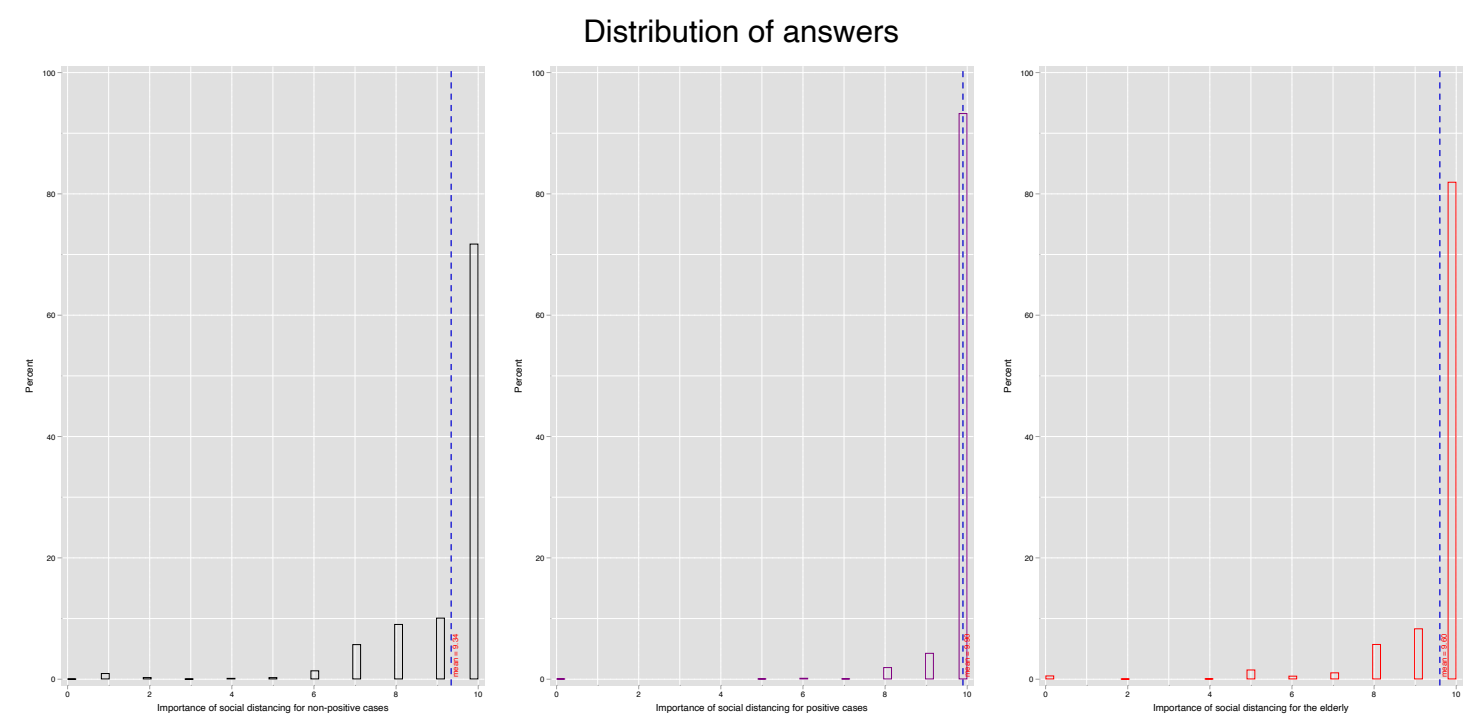

Figure S13: Knowledge of coronavirus-related questions by Italian respondents (weighted)

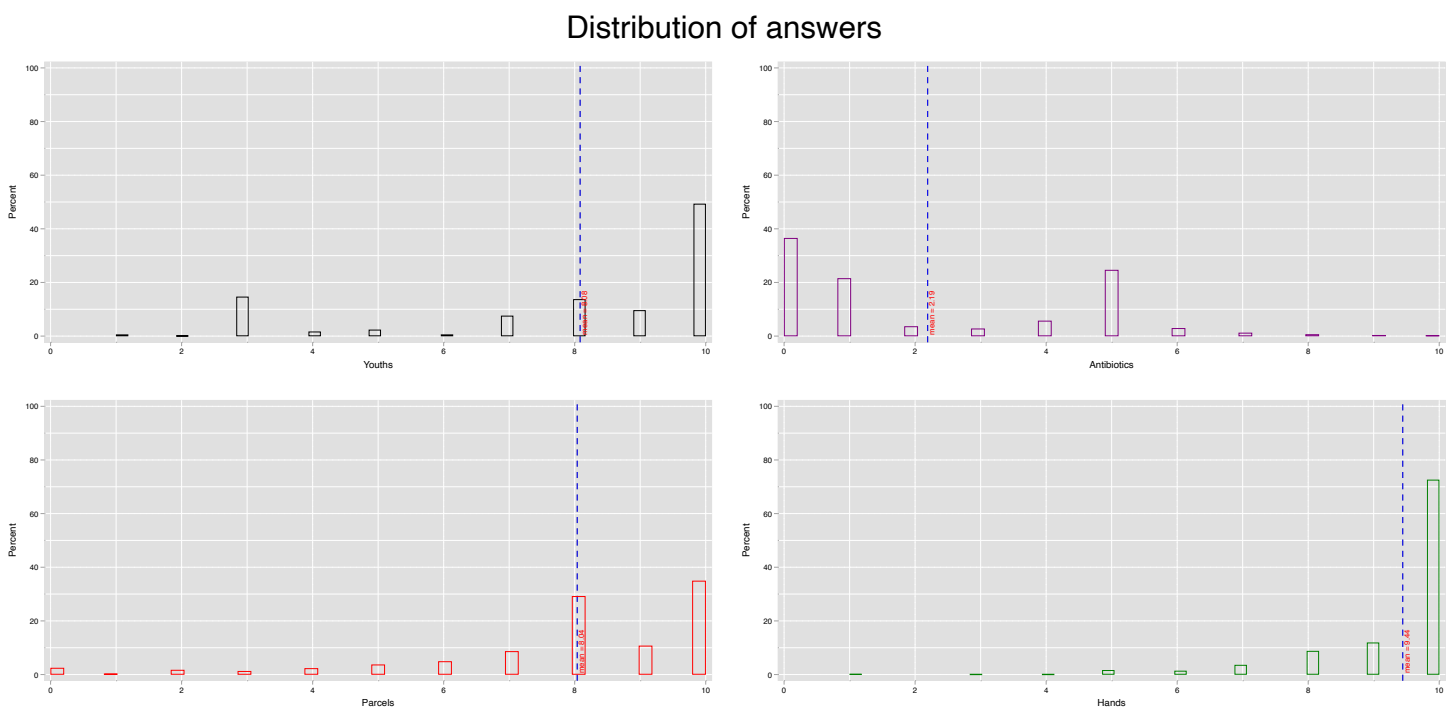


Tables The following tables show:

S10 The relationship between trust and perceived importance of social distancing measures. Observations are weighted to conform to the national population.

S11 The relationship between trust and perceived importance of social distancing measures. Observations are weighted. It includes a continuous variable for distance from outbreak areas instead of a dummy.

S12 The relationship between trust and perceived importance of social distancing measures. Observations are not weighted.

S13 The relationship between trust and perceived importance of social distancing measures. Observations are not weighted. Trust in science is the average between trust in science and trust in the Italian institute for public health. Trust in politicians is the average between trust in regional and national government.

S14 The relationship between trust and perceived importance of social distancing measures. Observations are not weighted. It includes the measures of trust in different models: trust in the Italian institute for public health (column 1), trust in regional government (column 2), trust in national government (column 3), trust in science (column 4) and all measures of trust (column 5). Note that the coefficient for trust in science is greater than the coefficient for any other trust measure.

S15 The relationship between trust and wrong beliefs. Observations are weighted to conform to the national population.

S16 The relationship between trust and wrong beliefs. Observations are not weighted.

S16 The relationship between trust and wrong beliefs. Observations are not weighted.

S17 The relationship between trust and wrong beliefs. Observations are not weighted. It includes a continuous variable for distance from outbreak areas instead of a dummy.

S18 The relationship between trust and wrong beliefs. Observations are not weighted. Trust in science is the average between trust in science and trust in the Italian institute for public health. Trust in politicians is the average between trust in regional and national government. 
S19 The relationship between trust and wrong beliefs measured on a scale from 0 to 10 as in the original questionnaire. Observations are not weighted.

S20 The relationship between trust and wrong beliefs. Observations are not weighted. It is estimated by Logit and marginal effects are reported.

S21 The relationship between holding wrong beliefs and support for containment measures. Holding wrong beliefs is measured with a dummy taking value 1 if the respondent has been at least wrong across the 4 treatment questions. Observations are weighted to conform to the national population.

S22 The relationship between holding wrong beliefs and support for containment measures. Holding wrong beliefs is measured as the sum of the distance from the correct answer (0 or 10) across the 4 treatment questions. Observations are weighted to conform to the national population.

S23 The treatment effect: i.e., receiving information for experts and willingness to update beliefs (when wrong). Observations are weighted to conform to the national population.

S24 The treatment effect: i.e., receiving information for experts and willingness to update beliefs (when wrong). Observations are not weighted.

S25 The treatment effect: i.e., receiving information from experts and willingness to update beliefs (when wrong). Observations are not weighted. It includes a continuous variable for distance from outbreak areas instead of a dummy.

S26 The treatment effect: i.e., receiving information from experts and willingness to update beliefs (when wrong). Observations are weighted to conform to the national population. It is estimated by Logit and marginal effects are reported.

S27 The interaction between receiving information from experts and a) science (columns 1-4), b) distance from outbreak areas (columns 5-8). Observations are weighted to conform to the national population.

S27 The relationship between trust and perceived importance of social distancing measures. It restricts the sample only to Lombardy and uses cumulative number of total cases tested positive for coronavirus at the 
municipality level instead of distance from outbreak areas. Observations are weighted.

S28 The relationship between trust and perceived importance of social distancing measures. It restricts the sample only to Lombardy and uses cumulative number of total cases tested positive for coronavirus at the municipality level instead of distance from outbreak areas. Observations are weighted.

S29 The relationship between trust and holding wrong beliefs. It restricts the sample only to Lombardy and uses cumulative number of total cases tested positive for coronavirus at the municipality level instead of distance from outbreak areas. Observations are weighted. 
Table S10: Trust and perceived importance of social distancing measures: Weighted

\begin{tabular}{|c|c|c|c|}
\hline & $\begin{array}{c}\text { (1) } \\
\text { Social distancing: non-positive } \\
\text { b/se }\end{array}$ & $\begin{array}{c}\text { (2) } \\
\text { Isolation: positive } \\
\mathrm{b} / \mathrm{se}\end{array}$ & $\begin{array}{c}\text { (3) } \\
\text { Social distancing: elderly } \\
\text { b/se }\end{array}$ \\
\hline Trust: science & $\begin{array}{l}0.021^{* *} \\
(0.008)\end{array}$ & $\begin{array}{c}0.003 \\
(0.003)\end{array}$ & $\begin{array}{l}0.017^{* *} \\
(0.005)\end{array}$ \\
\hline Trust: national government & $\begin{array}{c}-0.004 \\
(0.003)\end{array}$ & $\begin{array}{c}0.001 \\
(0.001)\end{array}$ & $\begin{array}{c}0.008^{*} \\
(0.004)\end{array}$ \\
\hline Trust: regional government & $\begin{array}{l}0.007^{*} \\
(0.003)\end{array}$ & $\begin{array}{l}-0.000 \\
(0.001)\end{array}$ & $\begin{array}{l}-0.000 \\
(0.002)\end{array}$ \\
\hline Trust: National Inst. Pub. Health & $\begin{array}{c}0.006 \\
(0.005)\end{array}$ & $\begin{array}{c}0.002 \\
(0.003)\end{array}$ & $\begin{array}{l}-0.004 \\
(0.003)\end{array}$ \\
\hline Gender & $\begin{array}{l}-0.111 \\
(0.122)\end{array}$ & $\begin{array}{l}-0.013 \\
(0.045)\end{array}$ & $\begin{array}{c}-0.028 \\
(0.163)\end{array}$ \\
\hline Age & $\begin{array}{l}0.013^{*} \\
(0.006)\end{array}$ & $\begin{array}{c}0.004^{*} \\
(0.002)\end{array}$ & $\begin{array}{c}0.004 \\
(0.005)\end{array}$ \\
\hline Secondary & $\begin{array}{l}-0.273 \\
(0.200)\end{array}$ & $\begin{array}{l}-0.022 \\
(0.057)\end{array}$ & $\begin{array}{c}-0.232^{*} \\
(0.095)\end{array}$ \\
\hline Bachelor & $\begin{array}{l}-0.275 \\
(0.185)\end{array}$ & $\begin{array}{l}-0.135 \\
(0.109)\end{array}$ & $\begin{array}{l}-0.282 \\
(0.205)\end{array}$ \\
\hline Master and Higher & $\begin{array}{c}-0.556^{*} \\
(0.210)\end{array}$ & $\begin{array}{c}-0.134^{*} \\
(0.065)\end{array}$ & $\begin{array}{c}-0.363^{* *} \\
(0.121)\end{array}$ \\
\hline Married & $\begin{array}{c}0.392 \\
(0.304)\end{array}$ & $\begin{array}{l}-0.048 \\
(0.056)\end{array}$ & $\begin{array}{c}0.219 \\
(0.149)\end{array}$ \\
\hline Cohabitation & $\begin{array}{l}0.478^{* *} \\
(0.168)\end{array}$ & $\begin{array}{c}0.017 \\
(0.027)\end{array}$ & $\begin{array}{c}0.165 \\
(0.158)\end{array}$ \\
\hline Divorced & $\begin{array}{c}0.122 \\
(0.324)\end{array}$ & $\begin{array}{l}-0.030 \\
(0.093)\end{array}$ & $\begin{array}{c}0.126 \\
(0.242)\end{array}$ \\
\hline Widow & $\begin{array}{c}0.529 \\
(0.434)\end{array}$ & $\begin{array}{l}-0.057 \\
(0.111)\end{array}$ & $\begin{array}{l}0.938^{+} \\
(0.503)\end{array}$ \\
\hline Has children & $\begin{array}{l}-0.098 \\
(0.164)\end{array}$ & $\begin{array}{l}-0.013 \\
(0.034)\end{array}$ & $\begin{array}{l}-0.015 \\
(0.119)\end{array}$ \\
\hline Housewife & $\begin{array}{r}-0.896^{+} \\
(0.467)\end{array}$ & $\begin{array}{c}0.011 \\
(0.054)\end{array}$ & $\begin{array}{c}-0.261 \\
(0.182)\end{array}$ \\
\hline Other & $\begin{array}{r}-0.498^{+} \\
(0.294)\end{array}$ & $\begin{array}{l}-0.076 \\
(0.066)\end{array}$ & $\begin{array}{l}-0.071 \\
(0.176)\end{array}$ \\
\hline Employed & $\begin{array}{l}-0.412 \\
(0.297)\end{array}$ & $\begin{array}{l}-0.010 \\
(0.040)\end{array}$ & $\begin{array}{l}-0.261 \\
(0.189)\end{array}$ \\
\hline Retired & $\begin{array}{l}-0.190 \\
(0.402)\end{array}$ & $\begin{array}{l}-0.082 \\
(0.070)\end{array}$ & $\begin{array}{r}-1.001^{+} \\
(0.538)\end{array}$ \\
\hline Student & $\begin{array}{l}-0.285 \\
(0.296)\end{array}$ & $\begin{array}{c}-0.079 \\
(0.080)\end{array}$ & $\begin{array}{c}-0.216 \\
(0.183)\end{array}$ \\
\hline Math skills & $\begin{array}{c}0.132 \\
(0.218)\end{array}$ & $\begin{array}{c}0.167 \\
(0.115)\end{array}$ & $\begin{array}{c}0.038 \\
(0.175)\end{array}$ \\
\hline LR scale & $\begin{array}{l}-0.007 \\
(0.020)\end{array}$ & $\begin{array}{c}0.014 \\
(0.010)\end{array}$ & $\begin{array}{l}0.087^{* *} \\
(0.031)\end{array}$ \\
\hline Outbreak areas & $\begin{array}{l}-0.013 \\
(0.072)\end{array}$ & $\begin{array}{l}-0.032 \\
(0.040)\end{array}$ & $\begin{array}{c}0.094 \\
(0.061)\end{array}$ \\
\hline Lombardy & $\begin{array}{l}-0.065 \\
(0.171)\end{array}$ & $\begin{array}{l}-0.063 \\
(0.046)\end{array}$ & $\begin{array}{l}-0.169 \\
(0.218)\end{array}$ \\
\hline Veneto & $\begin{array}{l}-0.137 \\
(0.154)\end{array}$ & $\begin{array}{c}-0.120^{*} \\
(0.055)\end{array}$ & $\begin{array}{l}-0.135 \\
(0.172)\end{array}$ \\
\hline Latitude & $\begin{array}{l}-0.069 \\
(0.050)\end{array}$ & $\begin{array}{c}0.021 \\
(0.017)\end{array}$ & $\begin{array}{l}-0.006 \\
(0.044)\end{array}$ \\
\hline Constant & $\begin{array}{c}9.820^{* * *} \\
(2.214)\end{array}$ & $\begin{array}{c}8.272^{* * *} \\
(0.807)\end{array}$ & $\begin{array}{c}8.239^{* * *} \\
(1.895)\end{array}$ \\
\hline N. & 929.000 & 928.000 & 928.000 \\
\hline$R^{2}$ & 0.155 & 0.059 & 0.185 \\
\hline
\end{tabular}

OLS. Standard errors clustered at the province-level reported in parentheses. Covariates as described in Table S7. $+\mathrm{p}<0.10,{ }^{*} \mathrm{p}<0.05,{ }^{*} \mathrm{p}<0.01,{ }^{*} \mathrm{p}<0.001$ 
Table S11: Trust and perceived importance of social distancing measures: Weighted

\begin{tabular}{|c|c|c|c|}
\hline & $\begin{array}{c}\text { (1) } \\
\text { Social distancing: non-positive } \\
\text { b/se }\end{array}$ & $\begin{array}{c}\text { (2) } \\
\text { Isolation: positive } \\
\mathrm{b} / \mathrm{se}\end{array}$ & $\begin{array}{c}\text { (3) } \\
\text { Social distancing: elderly } \\
\text { b/se }\end{array}$ \\
\hline Trust: science & $\begin{array}{l}0.021^{* *} \\
(0.008)\end{array}$ & $\begin{array}{c}0.003 \\
(0.003)\end{array}$ & $\begin{array}{l}0.017^{* *} \\
(0.005)\end{array}$ \\
\hline Trust: national government & $\begin{array}{l}-0.004 \\
(0.002)\end{array}$ & $\begin{array}{c}0.001 \\
(0.001)\end{array}$ & $\begin{array}{c}0.008^{*} \\
(0.004)\end{array}$ \\
\hline Trust: regional government & $\begin{array}{l}0.007^{* *} \\
(0.003)\end{array}$ & $\begin{array}{l}-0.000 \\
(0.001)\end{array}$ & $\begin{array}{l}-0.000 \\
(0.002)\end{array}$ \\
\hline Trust: National Inst. Pub. Health & $\begin{array}{c}0.006 \\
(0.005)\end{array}$ & $\begin{array}{c}0.002 \\
(0.003)\end{array}$ & $\begin{array}{l}-0.004 \\
(0.003)\end{array}$ \\
\hline Gender & $\begin{array}{l}-0.114 \\
(0.121)\end{array}$ & $\begin{array}{l}-0.015 \\
(0.046)\end{array}$ & $\begin{array}{l}-0.025 \\
(0.162)\end{array}$ \\
\hline Age & $\begin{array}{l}0.013^{*} \\
(0.006)\end{array}$ & $\begin{array}{c}0.005^{*} \\
(0.002)\end{array}$ & $\begin{array}{c}0.004 \\
(0.005)\end{array}$ \\
\hline Secondary & $\begin{array}{l}-0.266 \\
(0.197)\end{array}$ & $\begin{array}{c}-0.021 \\
(0.056)\end{array}$ & $\begin{array}{c}-0.232^{*} \\
(0.093)\end{array}$ \\
\hline Bachelor & $\begin{array}{l}-0.267 \\
(0.181)\end{array}$ & $\begin{array}{l}-0.133 \\
(0.107)\end{array}$ & $\begin{array}{l}-0.284 \\
(0.205)\end{array}$ \\
\hline Master and Higher & $\begin{array}{c}-0.549^{*} \\
(0.208)\end{array}$ & $\begin{array}{c}-0.132^{*} \\
(0.065)\end{array}$ & $\begin{array}{c}-0.365^{* *} \\
(0.121)\end{array}$ \\
\hline Married & $\begin{array}{c}0.375 \\
(0.297)\end{array}$ & $\begin{array}{l}-0.055 \\
(0.055)\end{array}$ & $\begin{array}{c}0.229 \\
(0.143)\end{array}$ \\
\hline Cohabitation & $\begin{array}{l}0.466^{* *} \\
(0.164)\end{array}$ & $\begin{array}{c}0.014 \\
(0.027)\end{array}$ & $\begin{array}{c}0.169 \\
(0.154)\end{array}$ \\
\hline Divorced & $\begin{array}{c}0.111 \\
(0.319)\end{array}$ & $\begin{array}{c}-0.034 \\
(0.092)\end{array}$ & $\begin{array}{c}0.133 \\
(0.240)\end{array}$ \\
\hline Widow & $\begin{array}{c}0.479 \\
(0.431)\end{array}$ & $\begin{array}{l}-0.077 \\
(0.117)\end{array}$ & $\begin{array}{c}0.970^{*} \\
(0.478)\end{array}$ \\
\hline Has children & $\begin{array}{l}-0.086 \\
(0.156)\end{array}$ & $\begin{array}{l}-0.008 \\
(0.034)\end{array}$ & $\begin{array}{l}-0.021 \\
(0.117)\end{array}$ \\
\hline Housewife & $\begin{array}{r}-0.899^{+} \\
(0.473)\end{array}$ & $\begin{array}{c}0.009 \\
(0.053)\end{array}$ & $\begin{array}{c}-0.260 \\
(0.182)\end{array}$ \\
\hline Other & $\begin{array}{l}-0.485 \\
(0.297)\end{array}$ & $\begin{array}{l}-0.072 \\
(0.067)\end{array}$ & $\begin{array}{l}-0.077 \\
(0.177)\end{array}$ \\
\hline Employed & $\begin{array}{l}-0.408 \\
(0.295)\end{array}$ & $\begin{array}{l}-0.009 \\
(0.040)\end{array}$ & $\begin{array}{c}-0.262 \\
(0.188)\end{array}$ \\
\hline Retired & $\begin{array}{l}-0.162 \\
(0.405)\end{array}$ & $\begin{array}{l}-0.074 \\
(0.070)\end{array}$ & $\begin{array}{c}-1.007^{+} \\
(0.530)\end{array}$ \\
\hline Student & $\begin{array}{c}-0.288 \\
(0.296)\end{array}$ & $\begin{array}{c}-0.080 \\
(0.079)\end{array}$ & $\begin{array}{l}-0.214 \\
(0.183)\end{array}$ \\
\hline Math skills & $\begin{array}{c}0.138 \\
(0.220)\end{array}$ & $\begin{array}{c}0.168 \\
(0.116)\end{array}$ & $\begin{array}{c}0.040 \\
(0.174)\end{array}$ \\
\hline LR scale & $\begin{array}{l}-0.005 \\
(0.021)\end{array}$ & $\begin{array}{c}0.014 \\
(0.010)\end{array}$ & $\begin{array}{l}0.087^{* *} \\
(0.031)\end{array}$ \\
\hline Distance from outbreak areas & $\begin{array}{c}0.001 \\
(0.001)\end{array}$ & $\begin{array}{c}0.000 \\
(0.000)\end{array}$ & $\begin{array}{l}-0.000 \\
(0.001)\end{array}$ \\
\hline Lombardy & $\begin{array}{l}-0.023 \\
(0.168)\end{array}$ & $\begin{array}{l}-0.052 \\
(0.052)\end{array}$ & $\begin{array}{l}-0.175 \\
(0.219)\end{array}$ \\
\hline Veneto & $\begin{array}{l}-0.144 \\
(0.154)\end{array}$ & $\begin{array}{c}-0.121^{*} \\
(0.059)\end{array}$ & $\begin{array}{l}-0.138 \\
(0.172)\end{array}$ \\
\hline Latitude & $\begin{array}{c}0.004 \\
(0.086)\end{array}$ & $\begin{array}{c}0.041 \\
(0.033)\end{array}$ & $\begin{array}{l}-0.020 \\
(0.087)\end{array}$ \\
\hline Constant & $\begin{array}{c}6.302 \\
(3.914)\end{array}$ & $\begin{array}{c}7.309^{* * *} \\
(1.644)\end{array}$ & $\begin{array}{l}8.891^{*} \\
(3.951)\end{array}$ \\
\hline N. & 929.000 & 928.000 & 928.000 \\
\hline$R^{2}$ & 0.157 & 0.059 & 0.185 \\
\hline
\end{tabular}

OLS. Standard errors clustered at the province-level reported in parentheses. Covariates as described in Table S7. $+\mathrm{p}<0.10,{ }^{*} \mathrm{p}<0.05,{ }^{*} \mathrm{p}<0.01,{ }^{*} \mathrm{p}<0.001$ 
Table S12: Trust and perceived importance of social distancing measures

\begin{tabular}{|c|c|c|c|}
\hline & $\begin{array}{c}\text { (1) } \\
\text { Social distancing: non-positive } \\
\text { b/se }\end{array}$ & $\begin{array}{c}(2) \\
\text { Isolation: positive } \\
\mathrm{b} / \mathrm{se}\end{array}$ & $\begin{array}{c}\text { (3) } \\
\text { Social distancing: elderly } \\
\text { b/se }\end{array}$ \\
\hline \multirow[t]{2}{*}{ Trust: science } & $0.025^{* * *}$ & $0.014^{* *}$ & $0.020^{* *}$ \\
\hline & $(0.007)$ & $(0.005)$ & $(0.006)$ \\
\hline \multirow[t]{2}{*}{ Trust: national government } & -0.000 & 0.002 & 0.001 \\
\hline & $(0.003)$ & $(0.002)$ & $(0.002)$ \\
\hline \multirow[t]{2}{*}{ Trust: regional government } & 0.006 & 0.000 & 0.002 \\
\hline & $(0.004)$ & $(0.001)$ & $(0.002)$ \\
\hline \multirow[t]{2}{*}{ Trust: National Inst. Pub. Health } & $0.016^{* *}$ & 0.001 & 0.001 \\
\hline & $(0.005)$ & $(0.004)$ & $(0.004)$ \\
\hline \multirow[t]{2}{*}{ Gender } & $-0.339^{* * *}$ & -0.038 & $-0.201^{*}$ \\
\hline & $(0.088)$ & $(0.050)$ & $(0.083)$ \\
\hline \multirow[t]{2}{*}{ Age } & 0.011 & $0.006^{+}$ & 0.000 \\
\hline & $(0.007)$ & $(0.003)$ & $(0.004)$ \\
\hline \multirow[t]{2}{*}{ Secondary } & -0.114 & -0.043 & $-0.271^{* * *}$ \\
\hline & $(0.218)$ & $(0.118)$ & $(0.075)$ \\
\hline \multirow[t]{2}{*}{ Bachelor } & -0.256 & -0.055 & $-0.341^{* *}$ \\
\hline & $(0.261)$ & $(0.112)$ & $(0.108)$ \\
\hline \multirow[t]{2}{*}{ Master and Higher } & $-0.426^{+}$ & -0.096 & $-0.480^{* * *}$ \\
\hline & $(0.222)$ & $(0.119)$ & $(0.086)$ \\
\hline \multirow[t]{2}{*}{ Married } & 0.053 & -0.036 & $0.170^{*}$ \\
\hline & $(0.121)$ & $(0.070)$ & $(0.085)$ \\
\hline \multirow[t]{2}{*}{ Cohabitation } & 0.139 & 0.025 & 0.118 \\
\hline & $(0.124)$ & $(0.034)$ & $(0.086)$ \\
\hline \multirow[t]{2}{*}{ Divorced } & 0.233 & 0.033 & 0.147 \\
\hline & $(0.229)$ & $(0.058)$ & $(0.134)$ \\
\hline \multirow[t]{2}{*}{ Widow } & 0.473 & 0.021 & 0.482 \\
\hline & $(0.350)$ & $(0.157)$ & $(0.350)$ \\
\hline \multirow[t]{2}{*}{ Has children } & $-0.270^{+}$ & -0.094 & 0.029 \\
\hline & $(0.155)$ & $(0.063)$ & $(0.073)$ \\
\hline \multirow[t]{2}{*}{ Housewife } & -0.001 & $0.165^{*}$ & -0.120 \\
\hline & $(0.375)$ & $(0.072)$ & $(0.179)$ \\
\hline \multirow[t]{2}{*}{ Other } & -0.086 & -0.016 & 0.008 \\
\hline & $(0.326)$ & $(0.068)$ & $(0.124)$ \\
\hline \multirow[t]{2}{*}{ Employed } & 0.084 & 0.025 & $-0.126^{*}$ \\
\hline & $(0.186)$ & $(0.066)$ & $(0.062)$ \\
\hline \multirow[t]{2}{*}{ Retired } & 0.325 & -0.014 & $-0.680^{+}$ \\
\hline & $(0.355)$ & $(0.065)$ & $(0.345)$ \\
\hline \multirow[t]{2}{*}{ Student } & -0.222 & -0.014 & $-0.226^{*}$ \\
\hline & $(0.208)$ & $(0.069)$ & $(0.094)$ \\
\hline \multirow[t]{2}{*}{ Math skills } & 0.130 & 0.369 & 0.242 \\
\hline & $(0.320)$ & $(0.321)$ & $(0.349)$ \\
\hline LR scale & -0.007 & 0.008 & $0.040^{+}$ \\
\hline & $(0.026)$ & $(0.014)$ & $(0.023)$ \\
\hline Outbreak areas & -0.128 & -0.061 & $0.096^{+}$ \\
\hline & $(0.147)$ & $(0.075)$ & $(0.056)$ \\
\hline Lombardy & 0.083 & -0.006 & 0.018 \\
\hline & $(0.115)$ & $(0.038)$ & $(0.102)$ \\
\hline Veneto & 0.124 & $-0.131^{+}$ & -0.043 \\
\hline & $(0.117)$ & $(0.072)$ & $(0.118)$ \\
\hline Latitude & -0.052 & 0.003 & $-0.048^{+}$ \\
\hline & $(0.047)$ & $(0.018)$ & $(0.028)$ \\
\hline Constant & $7.452^{* *}$ & $7.720^{* * *}$ & $9.700^{* * *}$ \\
\hline & $(2.279)$ & $(0.886)$ & $(1.217)$ \\
\hline N. & 924.000 & 923.000 & 923.000 \\
\hline$R^{2}$ & 0.139 & 0.090 & 0.078 \\
\hline
\end{tabular}

OLS. Standard errors clustered at the province-level reported in parentheses. Covariates as described in Table S7. $+\mathrm{p}<0.10,{ }^{*} \mathrm{p}<0.05,{ }^{*} \mathrm{p}<0.01,{ }^{*} \mathrm{p}<0.001$ 
Table S13: Trust and perceived importance of social distancing measures: Robustness

\begin{tabular}{|c|c|c|c|}
\hline & $\begin{array}{c}(1) \\
\text { Social distancing: non-positive } \\
\text { b/se }\end{array}$ & $\begin{array}{l}\text { (2) } \\
\text { Isolation: positive } \\
\text { b/se }\end{array}$ & $\begin{array}{c}(3) \\
\text { Social distancing: elderly } \\
\text { b/se }\end{array}$ \\
\hline \multirow[t]{2}{*}{ Trust science (avg) } & $0.038^{* * *}$ & $0.013^{* *}$ & $0.016^{* *}$ \\
\hline & $(0.007)$ & $(0.005)$ & $(0.005)$ \\
\hline \multirow[t]{2}{*}{ Trust politicians (avg) } & $0.006^{*}$ & 0.001 & 0.002 \\
\hline & $(0.003)$ & $(0.002)$ & $(0.003)$ \\
\hline \multirow[t]{2}{*}{ Gender } & $-0.355^{* * *}$ & -0.046 & $-0.218^{*}$ \\
\hline & $(0.094)$ & $(0.054)$ & $(0.085)$ \\
\hline \multirow[t]{2}{*}{ Age } & 0.010 & 0.005 & -0.001 \\
\hline & $(0.007)$ & $(0.003)$ & $(0.004)$ \\
\hline \multirow[t]{2}{*}{ Secondary } & -0.098 & -0.030 & $-0.248^{* *}$ \\
\hline & $(0.221)$ & $(0.118)$ & $(0.084)$ \\
\hline \multirow{2}{*}{ Bachelor } & -0.255 & -0.050 & $-0.334^{* *}$ \\
\hline & $(0.260)$ & $(0.109)$ & $(0.102)$ \\
\hline \multirow[t]{2}{*}{ Master and Higher } & $-0.411^{+}$ & -0.078 & $-0.453^{* * *}$ \\
\hline & $(0.223)$ & $(0.122)$ & $(0.083)$ \\
\hline \multirow[t]{2}{*}{ Married } & 0.069 & -0.012 & $0.206^{*}$ \\
\hline & $(0.124)$ & $(0.073)$ & $(0.094)$ \\
\hline \multirow[t]{2}{*}{ Cohabitation } & 0.143 & 0.040 & 0.139 \\
\hline & $(0.125)$ & $(0.038)$ & $(0.089)$ \\
\hline \multirow[t]{2}{*}{ Divorced } & 0.265 & 0.076 & 0.212 \\
\hline & $(0.227)$ & $(0.059)$ & $(0.136)$ \\
\hline \multirow[t]{2}{*}{ Widow } & 0.463 & 0.026 & 0.483 \\
\hline & $(0.358)$ & $(0.167)$ & $(0.381)$ \\
\hline \multirow[t]{2}{*}{ Has children } & $-0.266^{+}$ & -0.095 & 0.030 \\
\hline & $(0.157)$ & $(0.060)$ & $(0.071)$ \\
\hline \multirow[t]{2}{*}{ Housewife } & -0.040 & $0.141^{+}$ & -0.167 \\
\hline & $(0.370)$ & $(0.075)$ & $(0.188)$ \\
\hline \multirow[t]{2}{*}{ Other } & -0.098 & -0.023 & -0.006 \\
\hline & $(0.312)$ & $(0.070)$ & $(0.117)$ \\
\hline \multirow[t]{2}{*}{ Employed } & 0.089 & 0.024 & $-0.125^{*}$ \\
\hline & $(0.187)$ & $(0.066)$ & $(0.062)$ \\
\hline \multirow[t]{2}{*}{ Retired } & 0.237 & -0.030 & $-0.738^{*}$ \\
\hline & $(0.287)$ & $(0.063)$ & $(0.325)$ \\
\hline \multirow[t]{2}{*}{ Student } & -0.220 & -0.016 & $-0.227^{*}$ \\
\hline & $(0.211)$ & $(0.068)$ & $(0.092)$ \\
\hline \multirow[t]{2}{*}{ Math skills } & 0.131 & 0.382 & 0.259 \\
\hline & $(0.321)$ & $(0.328)$ & $(0.359)$ \\
\hline \multirow[t]{2}{*}{ LR scale } & 0.007 & 0.006 & $0.044^{+}$ \\
\hline & $(0.021)$ & $(0.012)$ & $(0.023)$ \\
\hline \multirow[t]{2}{*}{ Outbreak areas } & -0.106 & -0.058 & $0.109^{+}$ \\
\hline & $(0.144)$ & $(0.074)$ & $(0.059)$ \\
\hline \multirow[t]{2}{*}{ Lombardy } & 0.061 & -0.015 & -0.002 \\
\hline & $(0.111)$ & $(0.034)$ & $(0.098)$ \\
\hline \multirow[t]{2}{*}{ Veneto } & 0.102 & $-0.142^{*}$ & -0.066 \\
\hline & $(0.116)$ & $(0.066)$ & $(0.119)$ \\
\hline Latitude & -0.040 & 0.005 & -0.039 \\
\hline & $(0.044)$ & $(0.018)$ & $(0.027)$ \\
\hline Constant & $7.178^{* *}$ & $7.977^{* * *}$ & $9.882^{* * *}$ \\
\hline & $(2.216)$ & $(0.878)$ & $(1.216)$ \\
\hline N. & 924.000 & 923.000 & 923.000 \\
\hline$R^{2}$ & 0.136 & 0.079 & 0.068 \\
\hline
\end{tabular}

OLS. Standard errors clustered at the province-level reported in parentheses. Covariates as described in Table S7. $+\mathrm{p}<0.10,{ }^{*} \mathrm{p}<0.05,{ }^{*} \mathrm{p}<0.01, * \mathrm{p}<0.001$ 
Table S14: Trust and perceived importance of social distancing measures: Robustness

\begin{tabular}{|c|c|c|c|c|c|}
\hline & $\begin{array}{c}(1) \\
\mathrm{b} / \mathrm{se}\end{array}$ & $\begin{array}{c}(2) \\
b / s e\end{array}$ & $\begin{array}{c}(3) \\
b / s e\end{array}$ & $\begin{array}{c}(4) \\
b / s e\end{array}$ & $\begin{array}{c}(5) \\
b / s e\end{array}$ \\
\hline \multicolumn{6}{|l|}{ Social distancing: non-positive } \\
\hline Trust: National Inst. Pub. Health & $\begin{array}{c}0.028^{* * *} \\
(0.005)\end{array}$ & & & & $\begin{array}{l}0.015^{* *} \\
(0.005)\end{array}$ \\
\hline Trust: regional government & & $\begin{array}{c}0.013^{* * *} \\
(0.003)\end{array}$ & & & $\begin{array}{c}0.006 \\
(0.004)\end{array}$ \\
\hline Trust: national government & & & $\begin{array}{c}0.013^{* * *} \\
(0.003)\end{array}$ & & $\begin{array}{l}-0.000 \\
(0.003)\end{array}$ \\
\hline Trust: science & & & & $\begin{array}{c}0.041^{* * *} \\
(0.007)\end{array}$ & $\begin{array}{c}0.026^{* * *} \\
(0.007)\end{array}$ \\
\hline Constant & $\begin{array}{l}6.998^{* *} \\
(2.576) \\
\end{array}$ & $\begin{array}{c}12.682^{* * *} \\
(1.961)\end{array}$ & $\begin{array}{c}10.704^{* * *} \\
(2.001)\end{array}$ & $\begin{array}{c}6.655^{*} \\
(2.652) \\
\end{array}$ & $\begin{array}{c}6.691^{*} \\
(3.193) \\
\end{array}$ \\
\hline N. & 933.000 & 931.000 & 929.000 & 935.000 & 929.000 \\
\hline$R^{2}$ & 0.115 & 0.072 & 0.068 & 0.106 & 0.138 \\
\hline \multicolumn{6}{|l|}{ Isolation: positive } \\
\hline Trust: National Inst. Pub. Health & $\begin{array}{c}0.008 * \\
(0.003)\end{array}$ & & & & $\begin{array}{c}0.001 \\
(0.004)\end{array}$ \\
\hline Trust: regional government & & $\begin{array}{l}0.003^{* *} \\
(0.001)\end{array}$ & & & $\begin{array}{c}0.000 \\
(0.001)\end{array}$ \\
\hline Trust: national government & & & $\begin{array}{l}0.004^{* *} \\
(0.002)\end{array}$ & & $\begin{array}{c}0.002 \\
(0.002)\end{array}$ \\
\hline Trust: science & & & & $\begin{array}{c}0.017^{* * *} \\
(0.004)\end{array}$ & $\begin{array}{l}0.014^{* *} \\
(0.005)\end{array}$ \\
\hline Constant & $\begin{array}{c}8.446^{* * *} \\
(0.789)\end{array}$ & $\begin{array}{c}9.655^{* * *} \\
(0.852)\end{array}$ & $\begin{array}{c}9.064^{* * *} \\
(0.821)\end{array}$ & $\begin{array}{c}7.684^{* * *} \\
(0.871)\end{array}$ & $\begin{array}{c}7.943^{* * *} \\
(2.190)\end{array}$ \\
\hline N. & 933.000 & 931.000 & 928.000 & 935.000 & 928.000 \\
\hline$R^{2}$ & 0.059 & 0.042 & 0.050 & 0.094 & 0.090 \\
\hline \multicolumn{6}{|l|}{ Social distancing: elderly } \\
\hline Trust: National Inst. Pub. Health & $\begin{array}{c}0.010^{* * *} \\
(0.003)\end{array}$ & & & & $\begin{array}{c}0.000 \\
(0.004)\end{array}$ \\
\hline Trust: regional government & & $\begin{array}{l}0.005^{* *} \\
(0.002)\end{array}$ & & & $\begin{array}{c}0.003 \\
(0.002)\end{array}$ \\
\hline Trust: national government & & & $\begin{array}{l}0.006^{* *} \\
(0.002)\end{array}$ & & $\begin{array}{c}0.001 \\
(0.002)\end{array}$ \\
\hline Trust: science & & & & $\begin{array}{c}0.022^{* * *} \\
(0.005)\end{array}$ & $\begin{array}{l}0.021^{* *} \\
(0.006)\end{array}$ \\
\hline Constant & $\begin{array}{c}10.603^{* * *} \\
(1.217)\end{array}$ & $\begin{array}{c}11.979^{* * *} \\
(1.250)\end{array}$ & $\begin{array}{c}11.318^{* * *} \\
(1.228)\end{array}$ & $\begin{array}{c}9.805^{* * *} \\
(1.259)\end{array}$ & $\begin{array}{c}9.752^{* * *} \\
(2.528)\end{array}$ \\
\hline N. & 932.000 & 931.000 & 928.000 & 934.000 & 928.000 \\
\hline$R^{2}$ & 0.053 & 0.046 & 0.047 & 0.071 & 0.077 \\
\hline Controls & $\checkmark$ & $\checkmark$ & $\checkmark$ & $\checkmark$ & $\checkmark$ \\
\hline
\end{tabular}

OLS. Standard errors clustered at the province-level reported in parentheses. Covariates as described in Table S7. $+\mathrm{p}<0.10,{ }^{*} \mathrm{p}<0.05,{ }^{*} \mathrm{p}<0.01,{ }^{*} \mathrm{p}<0.001$ 
Table S15: Determinants of wrong beliefs: Weighted

\begin{tabular}{|c|c|c|c|c|}
\hline & $\begin{array}{c}(1) \\
\text { Wrong: Youths } \\
\text { b/se }\end{array}$ & $\begin{array}{c}(2) \\
\text { Wrong: Antibiotics } \\
\text { b/se }\end{array}$ & $\begin{array}{c}(3) \\
\text { Wrong: Parcels } \\
\text { b/se }\end{array}$ & $\begin{array}{c}\text { (4) } \\
\text { Wrong: Hands } \\
\text { b/se }\end{array}$ \\
\hline Trust: science & $\begin{array}{c}-0.008^{* * *} \\
(0.002)\end{array}$ & $\begin{array}{c}-0.011^{* * *} \\
(0.002)\end{array}$ & $\begin{array}{c}-0.008^{*} \\
(0.003)\end{array}$ & $\begin{array}{c}-0.012^{* * *} \\
(0.002)\end{array}$ \\
\hline Trust: national government & $\begin{array}{c}0.001 \\
(0.002)\end{array}$ & $\begin{array}{l}-0.002 \\
(0.002)\end{array}$ & $\begin{array}{c}0.001 \\
(0.003)\end{array}$ & $\begin{array}{l}0.002^{+} \\
(0.001)\end{array}$ \\
\hline Trust: regional government & $\begin{array}{l}-0.000 \\
(0.002)\end{array}$ & $\begin{array}{c}0.002 \\
(0.002)\end{array}$ & $\begin{array}{c}0.001 \\
(0.002)\end{array}$ & $\begin{array}{l}-0.001 \\
(0.002)\end{array}$ \\
\hline Trust: National Inst. Pub. Health & $\begin{array}{c}-0.006^{* *} \\
(0.002)\end{array}$ & $\begin{array}{c}0.001 \\
(0.002)\end{array}$ & $\begin{array}{l}-0.002 \\
(0.002)\end{array}$ & $\begin{array}{c}0.001 \\
(0.002)\end{array}$ \\
\hline Gender & $\begin{array}{c}0.095 \\
(0.066)\end{array}$ & $\begin{array}{c}0.018 \\
(0.062)\end{array}$ & $\begin{array}{l}0.106^{*} \\
(0.052)\end{array}$ & $\begin{array}{c}-0.091^{+} \\
(0.049)\end{array}$ \\
\hline Age & $\begin{array}{c}0.003 \\
(0.003)\end{array}$ & $\begin{array}{c}0.000 \\
(0.004)\end{array}$ & $\begin{array}{l}-0.004 \\
(0.004)\end{array}$ & $\begin{array}{c}-0.014^{* * *} \\
(0.002)\end{array}$ \\
\hline Secondary & $\begin{array}{c}-0.309^{* * *} \\
(0.089)\end{array}$ & $\begin{array}{l}-0.173 \\
(0.110)\end{array}$ & $\begin{array}{c}0.155 \\
(0.116)\end{array}$ & $\begin{array}{c}0.134 \\
(0.098)\end{array}$ \\
\hline Bachelor & $\begin{array}{c}-0.328^{* * *} \\
(0.088)\end{array}$ & $\begin{array}{c}-0.194^{+} \\
(0.108)\end{array}$ & $\begin{array}{l}0.203^{+} \\
(0.118)\end{array}$ & $\begin{array}{c}0.130 \\
(0.105)\end{array}$ \\
\hline Master and Higher & $\begin{array}{c}-0.326^{* * *} \\
(0.094)\end{array}$ & $\begin{array}{c}-0.312^{* *} \\
(0.109)\end{array}$ & $\begin{array}{c}0.087 \\
(0.133)\end{array}$ & $\begin{array}{c}0.046 \\
(0.094)\end{array}$ \\
\hline Married & $\begin{array}{l}-0.006 \\
(0.061)\end{array}$ & $\begin{array}{l}-0.110 \\
(0.141)\end{array}$ & $\begin{array}{l}-0.135 \\
(0.085)\end{array}$ & $\begin{array}{l}-0.075 \\
(0.082)\end{array}$ \\
\hline Cohabitation & $\begin{array}{c}0.070 \\
(0.079)\end{array}$ & $\begin{array}{c}-0.220^{+} \\
(0.125)\end{array}$ & $\begin{array}{c}-0.212^{* *} \\
(0.074)\end{array}$ & $\begin{array}{l}-0.111 \\
(0.078)\end{array}$ \\
\hline Divorced & $\begin{array}{c}-0.233^{+} \\
(0.129)\end{array}$ & $\begin{array}{c}-0.261^{+} \\
(0.131)\end{array}$ & $\begin{array}{c}0.021 \\
(0.097)\end{array}$ & $\begin{array}{c}0.060 \\
(0.102)\end{array}$ \\
\hline Widow & $\begin{array}{l}-0.344 \\
(0.272)\end{array}$ & $\begin{array}{l}-0.196 \\
(0.173)\end{array}$ & $\begin{array}{l}-0.233 \\
(0.190)\end{array}$ & $\begin{array}{l}-0.388^{*} \\
(0.153)\end{array}$ \\
\hline Has children & $\begin{array}{l}-0.038 \\
(0.050)\end{array}$ & $\begin{array}{l}0.197^{+} \\
(0.107)\end{array}$ & $\begin{array}{l}0.257^{*} \\
(0.104)\end{array}$ & $\begin{array}{l}0.201^{* *} \\
(0.068)\end{array}$ \\
\hline Housewife & $\begin{array}{l}-0.263 \\
(0.217)\end{array}$ & $\begin{array}{l}-0.165 \\
(0.256)\end{array}$ & $\begin{array}{c}0.201 \\
(0.160)\end{array}$ & $\begin{array}{c}0.142 \\
(0.158)\end{array}$ \\
\hline Other & $\begin{array}{l}-0.164 \\
(0.161)\end{array}$ & $\begin{array}{c}-0.091 \\
(0.200)\end{array}$ & $\begin{array}{c}0.011 \\
(0.124)\end{array}$ & $\begin{array}{c}0.158 \\
(0.100)\end{array}$ \\
\hline Employed & $\begin{array}{l}-0.144 \\
(0.097)\end{array}$ & $\begin{array}{c}0.070 \\
(0.093)\end{array}$ & $\begin{array}{c}0.000 \\
(0.102)\end{array}$ & $\begin{array}{l}0.221^{\text {** }} \\
(0.073)\end{array}$ \\
\hline Retired & $\begin{array}{l}-0.133 \\
(0.185)\end{array}$ & $\begin{array}{l}0.174^{+} \\
(0.100)\end{array}$ & $\begin{array}{l}0.339^{*} \\
(0.167)\end{array}$ & $\begin{array}{c}0.499^{* * * *} \\
(0.141)\end{array}$ \\
\hline Student & $\begin{array}{c}-0.181^{+} \\
(0.099)\end{array}$ & $\begin{array}{l}-0.108 \\
(0.086)\end{array}$ & $\begin{array}{l}-0.043 \\
(0.090)\end{array}$ & $\begin{array}{l}0.038 \\
(0.077)\end{array}$ \\
\hline Math skills & $\begin{array}{c}0.004 \\
(0.103)\end{array}$ & $\begin{array}{l}0.336^{* *} \\
(0.103)\end{array}$ & $\begin{array}{c}0.006 \\
(0.102)\end{array}$ & $\begin{array}{l}-0.000 \\
(0.129)\end{array}$ \\
\hline LR scale & $\begin{array}{l}-0.004 \\
(0.019)\end{array}$ & $\begin{array}{l}-0.038^{*} \\
(0.014)\end{array}$ & $\begin{array}{c}0.009 \\
(0.015)\end{array}$ & $\begin{array}{c}-0.021^{*} \\
(0.010)\end{array}$ \\
\hline Outbreak areas & $\begin{array}{l}-0.036 \\
(0.051)\end{array}$ & $\begin{array}{c}0.082 \\
(0.099)\end{array}$ & $\begin{array}{l}-0.047 \\
(0.066)\end{array}$ & $\begin{array}{l}-0.106^{*} \\
(0.053)\end{array}$ \\
\hline Lombardy & $\begin{array}{l}0.146^{*} \\
(0.073)\end{array}$ & $\begin{array}{c}-0.092 \\
(0.094)\end{array}$ & $\begin{array}{l}-0.031 \\
(0.110)\end{array}$ & $\begin{array}{l}0.160^{*} \\
(0.078)\end{array}$ \\
\hline Veneto & $\begin{array}{l}0.143^{*} \\
(0.061)\end{array}$ & $\begin{array}{l}-0.141 \\
(0.087)\end{array}$ & $\begin{array}{l}-0.140 \\
(0.103)\end{array}$ & $\begin{array}{c}0.066 \\
(0.082)\end{array}$ \\
\hline Latitude & $\begin{array}{c}-0.035^{+} \\
(0.021)\end{array}$ & $\begin{array}{l}-0.008 \\
(0.026)\end{array}$ & $\begin{array}{c}0.001 \\
(0.033)\end{array}$ & $\begin{array}{l}-0.042 \\
(0.032)\end{array}$ \\
\hline Constant & $\begin{array}{c}3.442^{* * *} \\
(0.936)\end{array}$ & $\begin{array}{l}1.945^{+} \\
(1.141)\end{array}$ & $\begin{array}{c}1.224 \\
(1.495)\end{array}$ & $\begin{array}{l}3.462^{*} \\
(1.489)\end{array}$ \\
\hline $\begin{array}{l}\text { N. } \\
R^{2}\end{array}$ & $\begin{array}{c}926.000 \\
0.399\end{array}$ & $\begin{array}{c}766.000 \\
0.310\end{array}$ & $\begin{array}{c}921.000 \\
0.258\end{array}$ & $\begin{array}{c}926.000 \\
0.225\end{array}$ \\
\hline
\end{tabular}

Weighted OLS. Standard errors clustered at the province-level reported in parentheses.

Covariates as described in Table S7. $+\mathrm{p}<0.10,{ }^{*} \mathrm{p}<0.05,{ }^{*} \mathrm{p}<0.01,{ }^{*} \mathrm{p}<0.001$ 
Table S16: Determinants of wrong beliefs

\begin{tabular}{|c|c|c|c|c|}
\hline & $\begin{array}{c}\text { (1) } \\
\text { Wrong: Youths } \\
\text { b/se }\end{array}$ & $\begin{array}{c}\text { (2) } \\
\text { Wrong: Antibiotics } \\
\text { b/se }\end{array}$ & $\begin{array}{c}(3) \\
\text { Wrong: Parcels } \\
\text { b/se }\end{array}$ & $\begin{array}{c}\text { (4) } \\
\text { Wrong: Hands } \\
\text { b/se }\end{array}$ \\
\hline Trust: science & $\begin{array}{c}-0.011^{* * *} \\
(0.003)\end{array}$ & $\begin{array}{c}-0.008^{* * *} \\
(0.002)\end{array}$ & $\begin{array}{c}-0.011^{* * *} \\
(0.002)\end{array}$ & $\begin{array}{c}-0.012^{* * *} \\
(0.001)\end{array}$ \\
\hline Trust: national government & $\begin{array}{c}0.001 \\
(0.001)\end{array}$ & $\begin{array}{c}0.000 \\
(0.001)\end{array}$ & $\begin{array}{c}-0.002 \\
(0.001)\end{array}$ & $\begin{array}{c}0.000 \\
(0.001)\end{array}$ \\
\hline Trust: regional government & $\begin{array}{c}0.000 \\
(0.001)\end{array}$ & $\begin{array}{c}-0.001 \\
(0.001)\end{array}$ & $\begin{array}{c}0.001 \\
(0.001)\end{array}$ & $\begin{array}{c}-0.001 \\
(0.001)\end{array}$ \\
\hline Trust: National Inst. Pub. Health & $\begin{array}{l}-0.003 \\
(0.002)\end{array}$ & $\begin{array}{c}0.002 \\
(0.002)\end{array}$ & $\begin{array}{c}0.001 \\
(0.002)\end{array}$ & $\begin{array}{c}0.001 \\
(0.001)\end{array}$ \\
\hline Gender & $\begin{array}{c}0.045 \\
(0.038)\end{array}$ & $\begin{array}{l}-0.037 \\
(0.039)\end{array}$ & $\begin{array}{c}0.003 \\
(0.030)\end{array}$ & $\begin{array}{l}-0.019 \\
(0.033)\end{array}$ \\
\hline Age & $\begin{array}{l}0.005^{* *} \\
(0.002)\end{array}$ & $\begin{array}{l}-0.004 \\
(0.003)\end{array}$ & $\begin{array}{c}0.001 \\
(0.002)\end{array}$ & $\begin{array}{c}-0.009^{* * *} \\
(0.002)\end{array}$ \\
\hline Secondary & $\begin{array}{c}-0.222^{+} \\
(0.130)\end{array}$ & $\begin{array}{l}-0.047 \\
(0.117)\end{array}$ & $\begin{array}{l}-0.089 \\
(0.115)\end{array}$ & $\begin{array}{c}0.042 \\
(0.144)\end{array}$ \\
\hline Bachelor & $\begin{array}{l}-0.211 \\
(0.127)\end{array}$ & $\begin{array}{l}-0.017 \\
(0.106)\end{array}$ & $\begin{array}{l}-0.026 \\
(0.133)\end{array}$ & $\begin{array}{c}0.112 \\
(0.151)\end{array}$ \\
\hline Master and Higher & $\begin{array}{l}-0.261^{*} \\
(0.124)\end{array}$ & $\begin{array}{l}-0.138 \\
(0.120)\end{array}$ & $\begin{array}{l}-0.137 \\
(0.124)\end{array}$ & $\begin{array}{c}0.003 \\
(0.131)\end{array}$ \\
\hline Married & $\begin{array}{l}-0.065 \\
(0.040)\end{array}$ & $\begin{array}{l}-0.023 \\
(0.088)\end{array}$ & $\begin{array}{l}-0.002 \\
(0.054)\end{array}$ & $\begin{array}{c}0.028 \\
(0.063)\end{array}$ \\
\hline Cohabitation & $\begin{array}{l}-0.031 \\
(0.035)\end{array}$ & $\begin{array}{c}0.005 \\
(0.072)\end{array}$ & $\begin{array}{c}0.011 \\
(0.066)\end{array}$ & $\begin{array}{c}0.037 \\
(0.050)\end{array}$ \\
\hline Divorced & $\begin{array}{l}-0.061 \\
(0.077)\end{array}$ & $\begin{array}{c}-0.173^{+} \\
(0.091)\end{array}$ & $\begin{array}{l}-0.024 \\
(0.084)\end{array}$ & $\begin{array}{c}0.063 \\
(0.080)\end{array}$ \\
\hline Widow & $\begin{array}{l}-0.271 \\
(0.315)\end{array}$ & $\begin{array}{l}-0.117 \\
(0.276)\end{array}$ & $\begin{array}{l}-0.428^{*} \\
(0.162)\end{array}$ & $\begin{array}{c}-0.362^{* *} \\
(0.125)\end{array}$ \\
\hline Has children & $\begin{array}{l}-0.003 \\
(0.035)\end{array}$ & $\begin{array}{l}0.198^{* *} \\
(0.074)\end{array}$ & $\begin{array}{c}0.061 \\
(0.043)\end{array}$ & $\begin{array}{c}0.073 \\
(0.054)\end{array}$ \\
\hline Housewife & $\begin{array}{l}-0.060 \\
(0.142)\end{array}$ & $\begin{array}{l}-0.064 \\
(0.165)\end{array}$ & $\begin{array}{l}-0.098 \\
(0.109)\end{array}$ & $\begin{array}{l}-0.020 \\
(0.119)\end{array}$ \\
\hline Other & $\begin{array}{l}-0.118 \\
(0.088)\end{array}$ & $\begin{array}{c}-0.178^{+} \\
(0.100)\end{array}$ & $\begin{array}{c}-0.071 \\
(0.086)\end{array}$ & $\begin{array}{c}0.007 \\
(0.092)\end{array}$ \\
\hline Employed & $\begin{array}{c}-0.032 \\
(0.048)\end{array}$ & $\begin{array}{c}-0.051 \\
(0.072)\end{array}$ & $\begin{array}{l}-0.023 \\
(0.041)\end{array}$ & $\begin{array}{c}0.028 \\
(0.056)\end{array}$ \\
\hline Retired & $\begin{array}{l}-0.117 \\
(0.136)\end{array}$ & $\begin{array}{c}0.176 \\
(0.149)\end{array}$ & $\begin{array}{l}0.315^{* *} \\
(0.098)\end{array}$ & $\begin{array}{l}0.364^{* *} \\
(0.122)\end{array}$ \\
\hline Student & $\begin{array}{l}-0.030 \\
(0.051)\end{array}$ & $\begin{array}{l}-0.065 \\
(0.072)\end{array}$ & $\begin{array}{c}0.002 \\
(0.048)\end{array}$ & $\begin{array}{l}-0.015 \\
(0.059)\end{array}$ \\
\hline Math skills & $\begin{array}{l}-0.009 \\
(0.084)\end{array}$ & $\begin{array}{c}0.088 \\
(0.078)\end{array}$ & $\begin{array}{c}0.056 \\
(0.077)\end{array}$ & $\begin{array}{l}0.123^{+} \\
(0.069)\end{array}$ \\
\hline LR scale & $\begin{array}{l}-0.000 \\
(0.006)\end{array}$ & $\begin{array}{c}0.006 \\
(0.009)\end{array}$ & $\begin{array}{c}0.002 \\
(0.009)\end{array}$ & $\begin{array}{c}0.004 \\
(0.006)\end{array}$ \\
\hline Outbreak areas & $\begin{array}{l}0.155^{*} \\
(0.064)\end{array}$ & $\begin{array}{l}-0.005 \\
(0.051)\end{array}$ & $\begin{array}{l}-0.008 \\
(0.061)\end{array}$ & $\begin{array}{c}0.059 \\
(0.048)\end{array}$ \\
\hline Lombardy & $\begin{array}{c}0.041 \\
(0.045)\end{array}$ & $\begin{array}{l}-0.004 \\
(0.055)\end{array}$ & $\begin{array}{l}-0.065 \\
(0.047)\end{array}$ & $\begin{array}{l}-0.031 \\
(0.045)\end{array}$ \\
\hline Veneto & $\begin{array}{c}0.069 \\
(0.043)\end{array}$ & $\begin{array}{l}-0.020 \\
(0.047)\end{array}$ & $\begin{array}{l}-0.068 \\
(0.049)\end{array}$ & $\begin{array}{l}-0.045 \\
(0.048)\end{array}$ \\
\hline Latitude & $\begin{array}{l}-0.014 \\
(0.019)\end{array}$ & $\begin{array}{c}-0.024 \\
(0.021)\end{array}$ & $\begin{array}{l}-0.009 \\
(0.019)\end{array}$ & $\begin{array}{c}0.009 \\
(0.021)\end{array}$ \\
\hline Constant & $\begin{array}{l}2.224^{*} \\
(0.892)\end{array}$ & $\begin{array}{l}2.252^{*} \\
(0.918)\end{array}$ & $\begin{array}{l}2.052^{*} \\
(0.898)\end{array}$ & $\begin{array}{c}1.106 \\
(0.959)\end{array}$ \\
\hline $\begin{array}{l}\text { N. } \\
R^{2}\end{array}$ & $\begin{array}{c}926.000 \\
0.104\end{array}$ & $\begin{array}{c}766.000 \\
0.059\end{array}$ & $\begin{array}{c}921.000 \\
0.082\end{array}$ & $\begin{array}{c}926.000 \\
0.087\end{array}$ \\
\hline
\end{tabular}

OLS. Standard errors clustered at the province-level reported in parentheses. Covariates as described in Table S7. $+\mathrm{p}<0.10,{ }^{*} \mathrm{p}<0.05,{ }^{*} \mathrm{p}<0.01,{ }^{*} \mathrm{p}<0.001$ 
Table S17: Determinants of wrong beliefs: Robustness

\begin{tabular}{|c|c|c|c|c|}
\hline & $\begin{array}{c}\text { (1) } \\
\text { Wrong: Youths } \\
\text { b/se }\end{array}$ & $\begin{array}{c}(2) \\
\text { Wrong: Antibiotics } \\
\text { b/se }\end{array}$ & $\begin{array}{c}\text { (3) } \\
\text { Wrong: Parcels } \\
\text { b/se }\end{array}$ & $\begin{array}{c}\text { (4) } \\
\text { Wrong: Hands } \\
\text { b/se }\end{array}$ \\
\hline Trust: science & $\begin{array}{c}-0.011^{* * *} \\
(0.003)\end{array}$ & $\begin{array}{c}-0.008^{* * *} \\
(0.002)\end{array}$ & $\begin{array}{c}-0.011^{* * *} \\
(0.002)\end{array}$ & $\begin{array}{c}-0.012^{* * *} \\
(0.001)\end{array}$ \\
\hline Trust: national government & $\begin{array}{c}0.001 \\
(0.001)\end{array}$ & $\begin{array}{c}0.000 \\
(0.001)\end{array}$ & $\begin{array}{l}-0.001 \\
(0.001)\end{array}$ & $\begin{array}{c}0.000 \\
(0.001)\end{array}$ \\
\hline Trust: regional government & $\begin{array}{c}0.001 \\
(0.001)\end{array}$ & $\begin{array}{c}-0.001 \\
(0.001)\end{array}$ & $\begin{array}{c}0.001 \\
(0.001)\end{array}$ & $\begin{array}{c}-0.001 \\
(0.001)\end{array}$ \\
\hline Trust: National Inst. Pub. Health & $\begin{array}{c}-0.002 \\
(0.002)\end{array}$ & $\begin{array}{c}0.002 \\
(0.002)\end{array}$ & $\begin{array}{c}0.000 \\
(0.001)\end{array}$ & $\begin{array}{c}0.001 \\
(0.001)\end{array}$ \\
\hline Gender & $\begin{array}{c}0.052 \\
(0.039)\end{array}$ & $\begin{array}{l}-0.038 \\
(0.038)\end{array}$ & $\begin{array}{c}0.000 \\
(0.031)\end{array}$ & $\begin{array}{l}-0.017 \\
(0.034)\end{array}$ \\
\hline Age & $\begin{array}{l}0.005^{* *} \\
(0.002)\end{array}$ & $\begin{array}{l}-0.004 \\
(0.003)\end{array}$ & $\begin{array}{c}0.001 \\
(0.002)\end{array}$ & $\begin{array}{c}-0.009^{* * *} \\
(0.002)\end{array}$ \\
\hline Secondary & $\begin{array}{c}-0.233^{+} \\
(0.128)\end{array}$ & $\begin{array}{l}-0.037 \\
(0.113)\end{array}$ & $\begin{array}{l}-0.086 \\
(0.111)\end{array}$ & $\begin{array}{c}0.040 \\
(0.140)\end{array}$ \\
\hline Bachelor & $\begin{array}{c}-0.219^{+} \\
(0.123)\end{array}$ & $\begin{array}{c}-0.012 \\
(0.104)\end{array}$ & $\begin{array}{l}-0.028 \\
(0.130)\end{array}$ & $\begin{array}{c}0.110 \\
(0.148)\end{array}$ \\
\hline Master and Higher & $\begin{array}{c}-0.275^{*} \\
(0.120)\end{array}$ & $\begin{array}{c}-0.128 \\
(0.117)\end{array}$ & $\begin{array}{l}-0.134 \\
(0.120)\end{array}$ & $\begin{array}{l}-0.000 \\
(0.127)\end{array}$ \\
\hline Married & $\begin{array}{l}-0.058 \\
(0.041)\end{array}$ & $\begin{array}{l}-0.023 \\
(0.088)\end{array}$ & $\begin{array}{l}-0.002 \\
(0.052)\end{array}$ & $\begin{array}{c}0.031 \\
(0.064)\end{array}$ \\
\hline Cohabitation & $\begin{array}{l}-0.033 \\
(0.035)\end{array}$ & $\begin{array}{c}0.006 \\
(0.072)\end{array}$ & $\begin{array}{c}0.012 \\
(0.067)\end{array}$ & $\begin{array}{c}0.037 \\
(0.050)\end{array}$ \\
\hline Divorced & $\begin{array}{l}-0.055 \\
(0.079)\end{array}$ & $\begin{array}{c}-0.176^{+} \\
(0.091)\end{array}$ & $\begin{array}{l}-0.027 \\
(0.086)\end{array}$ & $\begin{array}{c}0.065 \\
(0.081)\end{array}$ \\
\hline Widow & $\begin{array}{c}-0.211 \\
(0.366)\end{array}$ & $\begin{array}{l}-0.127 \\
(0.289)\end{array}$ & $\begin{array}{c}-0.437^{* *} \\
(0.161)\end{array}$ & $\begin{array}{c}-0.341^{*} \\
(0.142)\end{array}$ \\
\hline Has children & $\begin{array}{l}-0.005 \\
(0.036)\end{array}$ & $\begin{array}{c}0.193^{*} \\
(0.074)\end{array}$ & $\begin{array}{c}0.058 \\
(0.043)\end{array}$ & $\begin{array}{c}0.071 \\
(0.053)\end{array}$ \\
\hline Housewife & $\begin{array}{l}-0.033 \\
(0.139)\end{array}$ & $\begin{array}{l}-0.068 \\
(0.171)\end{array}$ & $\begin{array}{l}-0.101 \\
(0.111)\end{array}$ & $\begin{array}{l}-0.010 \\
(0.121)\end{array}$ \\
\hline Other & $\begin{array}{l}-0.107 \\
(0.088)\end{array}$ & $\begin{array}{c}-0.196^{+} \\
(0.100)\end{array}$ & $\begin{array}{l}-0.083 \\
(0.086)\end{array}$ & $\begin{array}{c}0.005 \\
(0.092)\end{array}$ \\
\hline Employed & $\begin{array}{l}-0.026 \\
(0.048)\end{array}$ & $\begin{array}{l}-0.057 \\
(0.072)\end{array}$ & $\begin{array}{l}-0.028 \\
(0.042)\end{array}$ & $\begin{array}{c}0.028 \\
(0.056)\end{array}$ \\
\hline Retired & $\begin{array}{l}-0.116 \\
(0.135)\end{array}$ & $\begin{array}{c}0.164 \\
(0.153)\end{array}$ & $\begin{array}{l}0.309^{* *} \\
(0.100)\end{array}$ & $\begin{array}{l}0.362^{* *} \\
(0.122)\end{array}$ \\
\hline Student & $\begin{array}{c}-0.027 \\
(0.053)\end{array}$ & $\begin{array}{c}-0.067 \\
(0.072)\end{array}$ & $\begin{array}{c}0.000 \\
(0.048)\end{array}$ & $\begin{array}{l}-0.015 \\
(0.059)\end{array}$ \\
\hline Math skills & $\begin{array}{c}0.004 \\
(0.079)\end{array}$ & $\begin{array}{c}0.079 \\
(0.079)\end{array}$ & $\begin{array}{c}0.043 \\
(0.077)\end{array}$ & $\begin{array}{l}0.123^{+} \\
(0.069)\end{array}$ \\
\hline LR scale & $\begin{array}{l}-0.001 \\
(0.006)\end{array}$ & $\begin{array}{c}0.006 \\
(0.009)\end{array}$ & $\begin{array}{c}0.002 \\
(0.009)\end{array}$ & $\begin{array}{c}0.004 \\
(0.006)\end{array}$ \\
\hline Distance from outbreak areas & $\begin{array}{c}0.000 \\
(0.000)\end{array}$ & $\begin{array}{c}-0.001^{+} \\
(0.000)\end{array}$ & $\begin{array}{c}-0.001^{+} \\
(0.000)\end{array}$ & $\begin{array}{l}-0.000 \\
(0.000)\end{array}$ \\
\hline Lombardy & $\begin{array}{c}0.063 \\
(0.049)\end{array}$ & $\begin{array}{l}-0.028 \\
(0.053)\end{array}$ & $\begin{array}{c}-0.085^{+} \\
(0.045)\end{array}$ & $\begin{array}{l}-0.030 \\
(0.048)\end{array}$ \\
\hline Veneto & $\begin{array}{c}0.067 \\
(0.040)\end{array}$ & $\begin{array}{l}-0.018 \\
(0.041)\end{array}$ & $\begin{array}{l}-0.062 \\
(0.048)\end{array}$ & $\begin{array}{l}-0.043 \\
(0.048)\end{array}$ \\
\hline Latitude & $\begin{array}{c}0.004 \\
(0.031)\end{array}$ & $\begin{array}{c}-0.066^{* *} \\
(0.024)\end{array}$ & $\begin{array}{l}-0.052 \\
(0.031)\end{array}$ & $\begin{array}{l}-0.002 \\
(0.029)\end{array}$ \\
\hline Constant & $\begin{array}{l}1.375 \\
(1.456)\end{array}$ & $\begin{array}{l}4.227^{* * *} \\
(1.134)\end{array}$ & $\begin{array}{l}4.101^{* *} \\
(1.486)\end{array}$ & $\begin{array}{l}1.646 \\
(1.390)\end{array}$ \\
\hline $\begin{array}{l}\text { N. } \\
R^{2}\end{array}$ & $\begin{array}{c}926.000 \\
0.098\end{array}$ & $\begin{array}{c}766.000 \\
0.062\end{array}$ & $\begin{array}{c}921.000 \\
0.084\end{array}$ & $\begin{array}{c}926.000 \\
0.087\end{array}$ \\
\hline
\end{tabular}

OLS. Standard errors clustered at the province-level reported in parentheses. Covariates as described in Table S7. $+\mathrm{p}<0.10,{ }^{*} \mathrm{p}<0.05,{ }^{*} \mathrm{p}<0.01,{ }^{*} \mathrm{p}<0.001$ 
Table S18: Determinants of wrong beliefs: Robustness

\begin{tabular}{|c|c|c|c|c|}
\hline & $\begin{array}{c}\text { (1) } \\
\text { Wrong: Youths } \\
\text { b/se }\end{array}$ & $\begin{array}{c}\text { (2) } \\
\text { Wrong: Antibiotics } \\
\text { b/se }\end{array}$ & $\begin{array}{c}\text { (3) } \\
\text { Wrong: Parcels } \\
\text { b/se }\end{array}$ & $\begin{array}{c}\text { (4) } \\
\text { Wrong: Hands } \\
\text { b/se }\end{array}$ \\
\hline Trust science (avg) & $\begin{array}{c}-0.012^{* * *} \\
(0.002)\end{array}$ & $\begin{array}{l}-0.004^{*} \\
(0.002)\end{array}$ & $\begin{array}{c}-0.008^{* * *} \\
(0.001)\end{array}$ & $\begin{array}{c}-0.008^{* * *} \\
(0.002)\end{array}$ \\
\hline Trust politicians (avg) & $\begin{array}{l}0.002^{*} \\
(0.001)\end{array}$ & $\begin{array}{c}0.000 \\
(0.001)\end{array}$ & $\begin{array}{c}0.000 \\
(0.001)\end{array}$ & $\begin{array}{c}0.000 \\
(0.001)\end{array}$ \\
\hline Gender & $\begin{array}{c}0.058 \\
(0.036)\end{array}$ & $\begin{array}{l}-0.030 \\
(0.037)\end{array}$ & $\begin{array}{c}0.006 \\
(0.030)\end{array}$ & $\begin{array}{l}-0.007 \\
(0.034)\end{array}$ \\
\hline Age & $\begin{array}{l}0.005^{* *} \\
(0.002)\end{array}$ & $\begin{array}{l}-0.003 \\
(0.003)\end{array}$ & $\begin{array}{c}0.001 \\
(0.002)\end{array}$ & $\begin{array}{c}-0.008^{* * *} \\
(0.002)\end{array}$ \\
\hline Secondary & $\begin{array}{c}-0.239^{+} \\
(0.124)\end{array}$ & $\begin{array}{c}-0.042 \\
(0.117)\end{array}$ & $\begin{array}{l}-0.093 \\
(0.116)\end{array}$ & $\begin{array}{c}0.031 \\
(0.141)\end{array}$ \\
\hline Bachelor & $\begin{array}{c}-0.218^{+} \\
(0.119)\end{array}$ & $\begin{array}{c}-0.009 \\
(0.106)\end{array}$ & $\begin{array}{c}-0.030 \\
(0.134)\end{array}$ & $\begin{array}{c}0.111 \\
(0.148)\end{array}$ \\
\hline Master and Higher & $\begin{array}{l}-0.283^{*} \\
(0.115)\end{array}$ & $\begin{array}{l}-0.135 \\
(0.120)\end{array}$ & $\begin{array}{c}-0.146 \\
(0.126)\end{array}$ & $\begin{array}{l}-0.012 \\
(0.129)\end{array}$ \\
\hline Married & $\begin{array}{c}-0.074^{+} \\
(0.040)\end{array}$ & $\begin{array}{l}-0.044 \\
(0.086)\end{array}$ & $\begin{array}{l}-0.025 \\
(0.052)\end{array}$ & $\begin{array}{c}0.008 \\
(0.068)\end{array}$ \\
\hline Cohabitation & $\begin{array}{l}-0.042 \\
(0.035)\end{array}$ & $\begin{array}{l}-0.006 \\
(0.069)\end{array}$ & $\begin{array}{l}-0.004 \\
(0.066)\end{array}$ & $\begin{array}{c}0.024 \\
(0.053)\end{array}$ \\
\hline Divorced & $\begin{array}{l}-0.083 \\
(0.085)\end{array}$ & $\begin{array}{l}-0.207^{*} \\
(0.091)\end{array}$ & $\begin{array}{l}-0.066 \\
(0.081)\end{array}$ & $\begin{array}{c}0.025 \\
(0.084)\end{array}$ \\
\hline Widow & $\begin{array}{c}-0.211 \\
(0.372)\end{array}$ & $\begin{array}{l}-0.147 \\
(0.265)\end{array}$ & $\begin{array}{c}-0.441^{* *} \\
(0.151)\end{array}$ & $\begin{array}{c}-0.339^{*} \\
(0.162)\end{array}$ \\
\hline Has children & $\begin{array}{l}-0.006 \\
(0.037)\end{array}$ & $\begin{array}{c}0.194^{*} \\
(0.073)\end{array}$ & $\begin{array}{c}0.059 \\
(0.045)\end{array}$ & $\begin{array}{c}0.070 \\
(0.054)\end{array}$ \\
\hline Housewife & $\begin{array}{l}-0.013 \\
(0.140)\end{array}$ & $\begin{array}{l}-0.047 \\
(0.167)\end{array}$ & $\begin{array}{l}-0.080 \\
(0.112)\end{array}$ & $\begin{array}{c}0.021 \\
(0.129)\end{array}$ \\
\hline Other & $\begin{array}{l}-0.102 \\
(0.089)\end{array}$ & $\begin{array}{r}-0.175^{+} \\
(0.095)\end{array}$ & $\begin{array}{l}-0.079 \\
(0.092)\end{array}$ & $\begin{array}{c}0.014 \\
(0.099)\end{array}$ \\
\hline Employed & $\begin{array}{l}-0.026 \\
(0.049)\end{array}$ & $\begin{array}{l}-0.061 \\
(0.071)\end{array}$ & $\begin{array}{l}-0.026 \\
(0.044)\end{array}$ & $\begin{array}{c}0.027 \\
(0.057)\end{array}$ \\
\hline Retired & $\begin{array}{l}-0.099 \\
(0.138)\end{array}$ & $\begin{array}{c}0.188 \\
(0.152)\end{array}$ & $\begin{array}{l}0.307^{\text {** }} \\
(0.102)\end{array}$ & $\begin{array}{l}0.398^{* *} \\
(0.116)\end{array}$ \\
\hline Student & $\begin{array}{l}-0.026 \\
(0.052)\end{array}$ & $\begin{array}{l}-0.070 \\
(0.072)\end{array}$ & $\begin{array}{c}0.003 \\
(0.046)\end{array}$ & $\begin{array}{l}-0.014 \\
(0.058)\end{array}$ \\
\hline Math skills & $\begin{array}{l}-0.005 \\
(0.077)\end{array}$ & $\begin{array}{c}0.069 \\
(0.080)\end{array}$ & $\begin{array}{c}0.027 \\
(0.074)\end{array}$ & $\begin{array}{c}0.112 \\
(0.078)\end{array}$ \\
\hline LR scale & $\begin{array}{l}-0.002 \\
(0.006)\end{array}$ & $\begin{array}{c}0.004 \\
(0.008)\end{array}$ & $\begin{array}{c}0.006 \\
(0.008)\end{array}$ & $\begin{array}{l}-0.000 \\
(0.005)\end{array}$ \\
\hline Distance from outbreak areas & $\begin{array}{c}0.000 \\
(0.000)\end{array}$ & $\begin{array}{c}-0.001^{+} \\
(0.000)\end{array}$ & $\begin{array}{c}-0.001^{+} \\
(0.000)\end{array}$ & $\begin{array}{l}-0.000 \\
(0.000)\end{array}$ \\
\hline Lombardy & $\begin{array}{c}0.071 \\
(0.049)\end{array}$ & $\begin{array}{l}-0.016 \\
(0.055)\end{array}$ & $\begin{array}{r}-0.079^{+} \\
(0.044)\end{array}$ & $\begin{array}{l}-0.017 \\
(0.046)\end{array}$ \\
\hline Veneto & $\begin{array}{l}0.076^{+} \\
(0.042)\end{array}$ & $\begin{array}{c}-0.003 \\
(0.043)\end{array}$ & $\begin{array}{c}-0.052 \\
(0.042)\end{array}$ & $\begin{array}{l}-0.028 \\
(0.046)\end{array}$ \\
\hline Latitude & $\begin{array}{c}0.001 \\
(0.033)\end{array}$ & $\begin{array}{c}-0.069^{* *} \\
(0.026)\end{array}$ & $\begin{array}{c}-0.054^{+} \\
(0.031)\end{array}$ & $\begin{array}{l}-0.007 \\
(0.032)\end{array}$ \\
\hline Constant & $\begin{array}{l}1.246 \\
(1.503)\end{array}$ & $\begin{array}{l}4.123^{* *} \\
(1.213)\end{array}$ & $\begin{array}{l}3.858^{*} \\
(1.484)\end{array}$ & $\begin{array}{l}1.503 \\
(1.501)\end{array}$ \\
\hline $\begin{array}{l}\text { N. } \\
R^{2}\end{array}$ & $\begin{array}{c}926.000 \\
0.087\end{array}$ & $\begin{array}{c}766.000 \\
0.050\end{array}$ & $\begin{array}{c}921.000 \\
0.065\end{array}$ & $\begin{array}{c}926.000 \\
0.065\end{array}$ \\
\hline
\end{tabular}

OLS. Standard errors clustered at the province-level reported in parentheses. Covariates as described in Table S7. $+\mathrm{p}<0.10,{ }^{*} \mathrm{p}<0.05,{ }^{*} \mathrm{p}<0.01,{ }^{*} \mathrm{p}<0.001$ 
Table S19: Determinants of wrong beliefs: Robustness

\begin{tabular}{|c|c|c|c|c|}
\hline & $\begin{array}{c}\text { (1) } \\
\text { How much wrong: Youths } \\
\text { b/se }\end{array}$ & $\begin{array}{c}(2) \\
\text { How much wrong: Antibiotics } \\
\text { b/se }\end{array}$ & $\begin{array}{c}(3) \\
\text { How much wrong: Parcels } \\
\text { b/se }\end{array}$ & $\begin{array}{c}\text { (4) } \\
\text { How much wrong: Hands } \\
\text { b/se }\end{array}$ \\
\hline Trust: science & $\begin{array}{c}-0.035^{* * *} \\
(0.008)\end{array}$ & $\begin{array}{l}-0.015 \\
(0.011)\end{array}$ & $\begin{array}{c}-0.037^{* * *} \\
(0.007)\end{array}$ & $\begin{array}{c}-0.027^{* * *} \\
(0.006)\end{array}$ \\
\hline Trust: national government & $\begin{array}{l}0.005^{+} \\
(0.003)\end{array}$ & $\begin{array}{c}0.007 \\
(0.005)\end{array}$ & $\begin{array}{c}-0.013^{* *} \\
(0.005)\end{array}$ & $\begin{array}{c}0.002 \\
(0.002)\end{array}$ \\
\hline Trust: regional government & $\begin{array}{c}-0.003 \\
(0.003)\end{array}$ & $\begin{array}{c}-0.003 \\
(0.004)\end{array}$ & $\begin{array}{c}0.006 \\
(0.004)\end{array}$ & $\begin{array}{c}-0.004^{+} \\
(0.002)\end{array}$ \\
\hline Trust: National Inst. Pub. Health & $\begin{array}{c}-0.010^{*} \\
(0.005)\end{array}$ & $\begin{array}{c}-0.003 \\
(0.007)\end{array}$ & $\begin{array}{c}-0.006 \\
(0.005)\end{array}$ & $\begin{array}{c}-0.005 \\
(0.004)\end{array}$ \\
\hline Gender & $\begin{array}{l}0.287^{*} \\
(0.129)\end{array}$ & $\begin{array}{c}0.088 \\
(0.143)\end{array}$ & $\begin{array}{l}-0.091 \\
(0.092)\end{array}$ & $\begin{array}{l}-0.006 \\
(0.088)\end{array}$ \\
\hline Age & $\begin{array}{c}0.008 \\
(0.005)\end{array}$ & $\begin{array}{l}-0.021 \\
(0.014)\end{array}$ & $\begin{array}{c}0.000 \\
(0.007)\end{array}$ & $\begin{array}{c}-0.015^{* * *} \\
(0.004)\end{array}$ \\
\hline Secondary & $\begin{array}{l}-0.845 \\
(0.597)\end{array}$ & $\begin{array}{c}-0.180 \\
(0.514)\end{array}$ & $\begin{array}{c}-0.051 \\
(0.462)\end{array}$ & $\begin{array}{c}0.027 \\
(0.314)\end{array}$ \\
\hline Bachelor & $\begin{array}{l}-0.885 \\
(0.602)\end{array}$ & $\begin{array}{l}-0.101 \\
(0.555)\end{array}$ & $\begin{array}{c}0.212 \\
(0.497)\end{array}$ & $\begin{array}{c}0.189 \\
(0.277)\end{array}$ \\
\hline Master and Higher & $\begin{array}{c}-0.870 \\
(0.581)\end{array}$ & $\begin{array}{c}-0.528 \\
(0.519)\end{array}$ & $\begin{array}{c}-0.332 \\
(0.457)\end{array}$ & $\begin{array}{c}-0.086 \\
(0.263)\end{array}$ \\
\hline Married & $\begin{array}{l}-0.261^{*} \\
(0.098)\end{array}$ & $\begin{array}{l}-0.154 \\
(0.331)\end{array}$ & $\begin{array}{c}0.187 \\
(0.258)\end{array}$ & $\begin{array}{l}-0.126 \\
(0.159)\end{array}$ \\
\hline Cohabitation & $\begin{array}{l}-0.136 \\
(0.121)\end{array}$ & $\begin{array}{c}0.102 \\
(0.218)\end{array}$ & $\begin{array}{c}0.042 \\
(0.218)\end{array}$ & $\begin{array}{l}-0.061 \\
(0.131)\end{array}$ \\
\hline Divorced & $\begin{array}{l}-0.080 \\
(0.266)\end{array}$ & $\begin{array}{l}-0.598 \\
(0.387)\end{array}$ & $\begin{array}{c}0.245 \\
(0.311)\end{array}$ & $\begin{array}{l}-0.002 \\
(0.240)\end{array}$ \\
\hline Widow & $\begin{array}{l}-1.163^{*} \\
(0.444)\end{array}$ & $\begin{array}{l}-1.058 \\
(0.636)\end{array}$ & $\begin{array}{c}-1.666^{* * *} \\
(0.405)\end{array}$ & $\begin{array}{r}-1.087^{*} \\
(0.432)\end{array}$ \\
\hline Has children & $\begin{array}{c}0.167 \\
(0.170)\end{array}$ & $\begin{array}{l}0.838^{*} \\
(0.378)\end{array}$ & $\begin{array}{l}0.347^{+} \\
(0.203)\end{array}$ & $\begin{array}{l}0.249^{*} \\
(0.103)\end{array}$ \\
\hline Housewife & $\begin{array}{c}-0.709^{*} \\
(0.300)\end{array}$ & $\begin{array}{c}-0.022 \\
(0.808)\end{array}$ & $\begin{array}{c}-0.543 \\
(0.583)\end{array}$ & $\begin{array}{c}-0.286 \\
(0.275)\end{array}$ \\
\hline Other & $\begin{array}{c}-0.519^{* *} \\
(0.184)\end{array}$ & $\begin{array}{l}-0.565 \\
(0.580)\end{array}$ & $\begin{array}{l}-0.432 \\
(0.293)\end{array}$ & $\begin{array}{l}-0.110 \\
(0.227)\end{array}$ \\
\hline Employed & $\begin{array}{l}-0.175 \\
(0.161)\end{array}$ & $\begin{array}{l}-0.333 \\
(0.364)\end{array}$ & $\begin{array}{l}-0.328 \\
(0.235)\end{array}$ & $\begin{array}{l}-0.024 \\
(0.131)\end{array}$ \\
\hline Retired & $\begin{array}{l}-0.409 \\
(0.396)\end{array}$ & $\begin{array}{l}-0.023 \\
(0.618)\end{array}$ & $\begin{array}{c}0.565 \\
(0.623)\end{array}$ & $\begin{array}{l}0.774^{+} \\
(0.439)\end{array}$ \\
\hline Student & $\begin{array}{l}-0.156 \\
(0.171)\end{array}$ & $\begin{array}{l}-0.333 \\
(0.335)\end{array}$ & $\begin{array}{c}-0.224 \\
(0.240)\end{array}$ & $\begin{array}{l}-0.147 \\
(0.163)\end{array}$ \\
\hline Math skills & $\begin{array}{l}-0.315 \\
(0.308)\end{array}$ & $\begin{array}{c}0.249 \\
(0.385)\end{array}$ & $\begin{array}{l}-0.050 \\
(0.357)\end{array}$ & $\begin{array}{l}0.296^{+} \\
(0.164)\end{array}$ \\
\hline LR scale & $\begin{array}{l}0.038^{+} \\
(0.022)\end{array}$ & $\begin{array}{c}0.075 \\
(0.050)\end{array}$ & $\begin{array}{c}0.000 \\
(0.036)\end{array}$ & $\begin{array}{c}0.015 \\
(0.019)\end{array}$ \\
\hline Outbreak areas & $\begin{array}{l}0.492^{* *} \\
(0.159)\end{array}$ & $\begin{array}{l}-0.061 \\
(0.231)\end{array}$ & $\begin{array}{c}0.229 \\
(0.236)\end{array}$ & $\begin{array}{c}0.185 \\
(0.161)\end{array}$ \\
\hline Lombardy & $\begin{array}{c}0.166 \\
(0.156)\end{array}$ & $\begin{array}{l}-0.080 \\
(0.269)\end{array}$ & $\begin{array}{l}-0.033 \\
(0.185)\end{array}$ & $\begin{array}{l}-0.181 \\
(0.122)\end{array}$ \\
\hline Veneto & $\begin{array}{l}0.299^{+} \\
(0.163)\end{array}$ & $\begin{array}{l}-0.155 \\
(0.239)\end{array}$ & $\begin{array}{c}0.035 \\
(0.190)\end{array}$ & $\begin{array}{c}-0.208^{+} \\
(0.124)\end{array}$ \\
\hline Latitude & $\begin{array}{l}-0.065 \\
(0.074)\end{array}$ & $\begin{array}{l}-0.098 \\
(0.091)\end{array}$ & $\begin{array}{l}-0.121 \\
(0.082)\end{array}$ & $\begin{array}{c}0.046 \\
(0.045)\end{array}$ \\
\hline Constant & $\begin{array}{l}8.352^{*} \\
(3.177)\end{array}$ & $\begin{array}{l}8.002^{+} \\
(4.088)\end{array}$ & $\begin{array}{c}11.651^{* *} \\
(3.807)\end{array}$ & $\begin{array}{c}1.959 \\
(2.051)\end{array}$ \\
\hline $\begin{array}{l}\text { N. } \\
R^{2}\end{array}$ & $\begin{array}{c}926.000 \\
0.126\end{array}$ & $\begin{array}{c}766.000 \\
0.043\end{array}$ & $\begin{array}{c}921.000 \\
0.104\end{array}$ & $\begin{array}{c}926.000 \\
0.102\end{array}$ \\
\hline
\end{tabular}

OLS. Standard errors clustered at the province-level reported in parentheses. Covariates as described in Table S7. $+\mathrm{p}<0.10,{ }^{*} \mathrm{p}<0.05,{ }^{*} \mathrm{p}<0.01,{ }^{*} \mathrm{p}<0.001$ 
Table S20: Determinants of wrong beliefs: Robustness

\begin{tabular}{|c|c|c|c|c|}
\hline & $\begin{array}{c}\text { (1) } \\
\text { Wrong: Youths } \\
\text { b/se }\end{array}$ & $\begin{array}{c}(2) \\
\text { Wrong: Antibiotics } \\
\text { b/se }\end{array}$ & $\begin{array}{c}\text { (3) } \\
\text { Wrong: Parcels } \\
\text { b/se }\end{array}$ & $\begin{array}{c}\text { (4) } \\
\text { Wrong: Hands } \\
\text { b/se }\end{array}$ \\
\hline Trust: science & $\begin{array}{c}-0.055^{* * *} \\
(0.013)\end{array}$ & $\begin{array}{c}-0.034^{* * *} \\
(0.010)\end{array}$ & $\begin{array}{c}-0.056^{* * *} \\
(0.012)\end{array}$ & $\begin{array}{c}-0.056^{* * *} \\
(0.008)\end{array}$ \\
\hline Trust: national government & $\begin{array}{c}0.005 \\
(0.003)\end{array}$ & $\begin{array}{c}0.001 \\
(0.005)\end{array}$ & $\begin{array}{l}-0.007 \\
(0.005)\end{array}$ & $\begin{array}{c}0.001 \\
(0.005)\end{array}$ \\
\hline Trust: regional government & $\begin{array}{c}0.002 \\
(0.005)\end{array}$ & $\begin{array}{l}-0.003 \\
(0.005)\end{array}$ & $\begin{array}{c}0.003 \\
(0.004)\end{array}$ & $\begin{array}{l}-0.005 \\
(0.004)\end{array}$ \\
\hline Trust: National Inst. Pub. Health & $\begin{array}{l}-0.012 \\
(0.008)\end{array}$ & $\begin{array}{c}0.008 \\
(0.008)\end{array}$ & $\begin{array}{c}0.001 \\
(0.007)\end{array}$ & $\begin{array}{c}0.004 \\
(0.007)\end{array}$ \\
\hline Gender & $\begin{array}{c}0.239 \\
(0.182)\end{array}$ & $\begin{array}{l}-0.152 \\
(0.163)\end{array}$ & $\begin{array}{c}0.022 \\
(0.131)\end{array}$ & $\begin{array}{l}-0.085 \\
(0.154)\end{array}$ \\
\hline Age & $\begin{array}{l}0.024^{* *} \\
(0.009)\end{array}$ & $\begin{array}{l}-0.016 \\
(0.013)\end{array}$ & $\begin{array}{c}0.001 \\
(0.009)\end{array}$ & $\begin{array}{c}-0.046^{* * *} \\
(0.009)\end{array}$ \\
\hline Secondary & $\begin{array}{c}-0.970^{+} \\
(0.570)\end{array}$ & $\begin{array}{l}-0.205 \\
(0.483)\end{array}$ & $\begin{array}{l}-0.412 \\
(0.509)\end{array}$ & $\begin{array}{c}0.189 \\
(0.701)\end{array}$ \\
\hline Bachelor & $\begin{array}{l}-0.903 \\
(0.557)\end{array}$ & $\begin{array}{l}-0.075 \\
(0.437)\end{array}$ & $\begin{array}{l}-0.130 \\
(0.583)\end{array}$ & $\begin{array}{c}0.511 \\
(0.723)\end{array}$ \\
\hline Master and Higher & $\begin{array}{l}-1.158^{*} \\
(0.541)\end{array}$ & $\begin{array}{l}-0.590 \\
(0.496)\end{array}$ & $\begin{array}{l}-0.622 \\
(0.544)\end{array}$ & $\begin{array}{c}0.013 \\
(0.642)\end{array}$ \\
\hline Married & $\begin{array}{r}-0.327^{+} \\
(0.198)\end{array}$ & $\begin{array}{l}-0.112 \\
(0.385)\end{array}$ & $\begin{array}{l}-0.006 \\
(0.231)\end{array}$ & $\begin{array}{c}0.126 \\
(0.313)\end{array}$ \\
\hline Cohabitation & $\begin{array}{l}-0.159 \\
(0.176)\end{array}$ & $\begin{array}{c}0.017 \\
(0.305)\end{array}$ & $\begin{array}{c}0.043 \\
(0.279)\end{array}$ & $\begin{array}{c}0.187 \\
(0.232)\end{array}$ \\
\hline Divorced & $\begin{array}{l}-0.298 \\
(0.380)\end{array}$ & $\begin{array}{c}-0.774^{+} \\
(0.416)\end{array}$ & $\begin{array}{l}-0.133 \\
(0.364)\end{array}$ & $\begin{array}{c}0.346 \\
(0.398)\end{array}$ \\
\hline Widow & $\begin{array}{l}-1.273 \\
(1.427)\end{array}$ & $\begin{array}{l}-0.525 \\
(1.221)\end{array}$ & $\begin{array}{l}-2.315^{*} \\
(0.921)\end{array}$ & $\begin{array}{c}0.000 \\
(.)\end{array}$ \\
\hline Has children & $\begin{array}{l}-0.001 \\
(0.173)\end{array}$ & $\begin{array}{l}0.858^{* *} \\
(0.328)\end{array}$ & $\begin{array}{c}0.292 \\
(0.186)\end{array}$ & $\begin{array}{c}0.394 \\
(0.267)\end{array}$ \\
\hline Housewife & $\begin{array}{l}-0.310 \\
(0.718)\end{array}$ & $\begin{array}{l}-0.284 \\
(0.699)\end{array}$ & $\begin{array}{l}-0.488 \\
(0.473)\end{array}$ & $\begin{array}{l}-0.041 \\
(0.581)\end{array}$ \\
\hline Other & $\begin{array}{l}-0.629 \\
(0.513)\end{array}$ & $\begin{array}{c}-0.789^{+} \\
(0.458)\end{array}$ & $\begin{array}{l}-0.325 \\
(0.366)\end{array}$ & $\begin{array}{c}0.078 \\
(0.449)\end{array}$ \\
\hline Employed & $\begin{array}{l}-0.160 \\
(0.231)\end{array}$ & $\begin{array}{l}-0.219 \\
(0.297)\end{array}$ & $\begin{array}{l}-0.112 \\
(0.179)\end{array}$ & $\begin{array}{c}0.157 \\
(0.267)\end{array}$ \\
\hline Retired & $\begin{array}{l}-0.557 \\
(0.604)\end{array}$ & $\begin{array}{c}0.796 \\
(0.738)\end{array}$ & $\begin{array}{l}1.891^{*} \\
(0.744)\end{array}$ & $\begin{array}{l}1.868^{* * *} \\
(0.553)\end{array}$ \\
\hline Student & $\begin{array}{l}-0.155 \\
(0.249)\end{array}$ & $\begin{array}{l}-0.284 \\
(0.298)\end{array}$ & $\begin{array}{l}-0.019 \\
(0.212)\end{array}$ & $\begin{array}{l}-0.076 \\
(0.278)\end{array}$ \\
\hline Math skills & $\begin{array}{l}-0.033 \\
(0.404)\end{array}$ & $\begin{array}{c}0.376 \\
(0.346)\end{array}$ & $\begin{array}{c}0.221 \\
(0.375)\end{array}$ & $\begin{array}{l}0.708^{+} \\
(0.429)\end{array}$ \\
\hline LR scale & $\begin{array}{l}-0.004 \\
(0.031)\end{array}$ & $\begin{array}{c}0.026 \\
(0.038)\end{array}$ & $\begin{array}{c}0.008 \\
(0.041)\end{array}$ & $\begin{array}{c}0.019 \\
(0.028)\end{array}$ \\
\hline Outbreak areas & $\begin{array}{l}0.718^{*} \\
(0.284)\end{array}$ & $\begin{array}{l}-0.023 \\
(0.214)\end{array}$ & $\begin{array}{l}-0.045 \\
(0.250)\end{array}$ & $\begin{array}{c}0.248 \\
(0.210)\end{array}$ \\
\hline Lombardy & $\begin{array}{c}0.234 \\
(0.247)\end{array}$ & $\begin{array}{l}-0.013 \\
(0.235)\end{array}$ & $\begin{array}{l}-0.284 \\
(0.204)\end{array}$ & $\begin{array}{l}-0.153 \\
(0.215)\end{array}$ \\
\hline Veneto & $\begin{array}{c}0.359 \\
(0.231)\end{array}$ & $\begin{array}{l}-0.087 \\
(0.201)\end{array}$ & $\begin{array}{l}-0.315 \\
(0.214)\end{array}$ & $\begin{array}{l}-0.229 \\
(0.231)\end{array}$ \\
\hline Latitude & $\begin{array}{l}-0.069 \\
(0.100)\end{array}$ & $\begin{array}{l}-0.105 \\
(0.092)\end{array}$ & $\begin{array}{l}-0.035 \\
(0.086)\end{array}$ & $\begin{array}{c}0.047 \\
(0.100)\end{array}$ \\
\hline Constant & $\begin{array}{l}8.271^{+} \\
(4.535)\end{array}$ & $\begin{array}{l}7.696^{+} \\
(4.075)\end{array}$ & $\begin{array}{l}7.397^{+} \\
(4.094)\end{array}$ & $\begin{array}{c}2.872 \\
(4.666)\end{array}$ \\
\hline $\begin{array}{l}\text { N. } \\
R^{2}\end{array}$ & 926.000 & 766.000 & 921.000 & 923.000 \\
\hline
\end{tabular}

Logit (mfx). Standard errors clustered at the province-level reported in parentheses. Covariates as described in Table S7. $+\mathrm{p}<0.10,{ }^{*} \mathrm{p}<0.05,{ }^{*} \mathrm{p}<0.01,{ }^{*} \mathrm{p}<0.001$ 
Table S21: Relationship between holding wrong beliefs and support for containment measures (Weighted)

\begin{tabular}{|c|c|c|c|}
\hline & $\begin{array}{c}\text { (1) } \\
\text { Social distancing: non-positive } \\
\text { b/se }\end{array}$ & $\begin{array}{c}\text { (2) } \\
\text { Isolation: positive } \\
\mathrm{b} / \mathrm{se}\end{array}$ & $\begin{array}{c}\text { (3) } \\
\text { Social distancing: elderly } \\
\mathrm{b} / \mathrm{se}\end{array}$ \\
\hline At lest once wrong & $\begin{array}{c}-0.479^{* * *} \\
(0.102)\end{array}$ & $\begin{array}{c}-0.094^{* * *} \\
(0.023)\end{array}$ & $\begin{array}{l}-0.024 \\
(0.129)\end{array}$ \\
\hline Trust: science & $\begin{array}{l}0.018^{+} \\
(0.009)\end{array}$ & $\begin{array}{c}0.003 \\
(0.004)\end{array}$ & $\begin{array}{l}0.019^{* *} \\
(0.006)\end{array}$ \\
\hline Trust: national government & $\begin{array}{c}-0.003 \\
(0.002)\end{array}$ & $\begin{array}{c}0.001 \\
(0.001)\end{array}$ & $\begin{array}{l}0.009^{+} \\
(0.005)\end{array}$ \\
\hline Trust: regional government & $\begin{array}{c}0.007^{*} \\
(0.003)\end{array}$ & $\begin{array}{c}-0.000 \\
(0.001)\end{array}$ & $\begin{array}{c}0.001 \\
(0.002)\end{array}$ \\
\hline Trust: National Inst. Pub. Health & $\begin{array}{c}0.007 \\
(0.007)\end{array}$ & $\begin{array}{c}0.002 \\
(0.004)\end{array}$ & $\begin{array}{c}-0.006 \\
(0.004)\end{array}$ \\
\hline Gender & $\begin{array}{c}-0.078 \\
(0.097)\end{array}$ & $\begin{array}{c}0.006 \\
(0.057)\end{array}$ & $\begin{array}{c}-0.026 \\
(0.146)\end{array}$ \\
\hline Age & $\begin{array}{c}0.012^{*} \\
(0.006)\end{array}$ & $\begin{array}{l}0.007^{* *} \\
(0.002)\end{array}$ & $\begin{array}{c}0.006 \\
(0.006)\end{array}$ \\
\hline Secondary & $\begin{array}{c}-0.184 \\
(0.251)\end{array}$ & $\begin{array}{c}0.026 \\
(0.087)\end{array}$ & $\begin{array}{c}0.008 \\
(0.157)\end{array}$ \\
\hline Bachelor & $\begin{array}{l}-0.095 \\
(0.332)\end{array}$ & $\begin{array}{c}-0.091 \\
(0.122)\end{array}$ & $\begin{array}{c}-0.055 \\
(0.255)\end{array}$ \\
\hline Master and Higher & $\begin{array}{c}-0.465^{+} \\
(0.242)\end{array}$ & $\begin{array}{l}-0.089 \\
(0.106)\end{array}$ & $\begin{array}{l}-0.187 \\
(0.169)\end{array}$ \\
\hline Married & $\begin{array}{c}0.305 \\
(0.385)\end{array}$ & $\begin{array}{c}0.010 \\
(0.068)\end{array}$ & $\begin{array}{c}0.175 \\
(0.181)\end{array}$ \\
\hline Cohabitation & $\begin{array}{l}0.452^{+} \\
(0.242)\end{array}$ & $\begin{array}{c}0.047 \\
(0.036)\end{array}$ & $\begin{array}{c}0.131 \\
(0.179)\end{array}$ \\
\hline Divorced & $\begin{array}{c}0.052 \\
(0.427)\end{array}$ & $\begin{array}{c}0.026 \\
(0.092)\end{array}$ & $\begin{array}{c}0.092 \\
(0.253)\end{array}$ \\
\hline Widow & $\begin{array}{c}0.604 \\
(0.541)\end{array}$ & $\begin{array}{c}0.014 \\
(0.124)\end{array}$ & $\begin{array}{l}0.998^{+} \\
(0.576)\end{array}$ \\
\hline Has children & $\begin{array}{c}0.028 \\
(0.172)\end{array}$ & $\begin{array}{c}-0.072^{*} \\
(0.030)\end{array}$ & $\begin{array}{c}0.015 \\
(0.152)\end{array}$ \\
\hline Housewife & $\begin{array}{r}-0.889^{+} \\
(0.491)\end{array}$ & $\begin{array}{c}0.032 \\
(0.070)\end{array}$ & $\begin{array}{l}-0.250 \\
(0.208)\end{array}$ \\
\hline Other & $\begin{array}{l}-0.576 \\
(0.355)\end{array}$ & $\begin{array}{l}-0.129 \\
(0.079)\end{array}$ & $\begin{array}{l}-0.127 \\
(0.223)\end{array}$ \\
\hline Employed & $\begin{array}{l}-0.501 \\
(0.368)\end{array}$ & $\begin{array}{l}-0.036 \\
(0.070)\end{array}$ & $\begin{array}{l}-0.388 \\
(0.251)\end{array}$ \\
\hline Retired & $\begin{array}{l}-0.153 \\
(0.478)\end{array}$ & $\begin{array}{c}-0.150 \\
(0.093)\end{array}$ & $\begin{array}{c}-1.109^{*} \\
(0.505)\end{array}$ \\
\hline Student & $\begin{array}{c}-0.363 \\
(0.286)\end{array}$ & $\begin{array}{l}-0.073 \\
(0.094)\end{array}$ & $\begin{array}{c}-0.292 \\
(0.177)\end{array}$ \\
\hline Math skills & $\begin{array}{l}-0.029 \\
(0.179)\end{array}$ & $\begin{array}{c}0.120 \\
(0.112)\end{array}$ & $\begin{array}{l}-0.015 \\
(0.178)\end{array}$ \\
\hline LR scale & $\begin{array}{l}-0.008 \\
(0.026)\end{array}$ & $\begin{array}{c}0.006 \\
(0.013)\end{array}$ & $\begin{array}{l}0.090^{* *} \\
(0.033)\end{array}$ \\
\hline Outbreak areas & $\begin{array}{c}0.019 \\
(0.114)\end{array}$ & $\begin{array}{c}0.024 \\
(0.051)\end{array}$ & $\begin{array}{c}0.251^{*} \\
(0.103)\end{array}$ \\
\hline Lombardy & $\begin{array}{c}0.061 \\
(0.244)\end{array}$ & $\begin{array}{c}-0.030 \\
(0.051)\end{array}$ & $\begin{array}{l}-0.134 \\
(0.171)\end{array}$ \\
\hline Veneto & $\begin{array}{c}0.039 \\
(0.234)\end{array}$ & $\begin{array}{r}-0.117^{+} \\
(0.069)\end{array}$ & $\begin{array}{l}-0.087 \\
(0.165)\end{array}$ \\
\hline Latitude & $\begin{array}{l}-0.079 \\
(0.062)\end{array}$ & $\begin{array}{c}0.020 \\
(0.020)\end{array}$ & $\begin{array}{l}-0.007 \\
(0.045)\end{array}$ \\
\hline Constant & $\begin{array}{c}10.803^{* * *} \\
(2.691) \\
\end{array}$ & $\begin{array}{c}8.238^{* * *} \\
(0.927)\end{array}$ & $\begin{array}{c}7.814^{* * *} \\
(2.013)\end{array}$ \\
\hline $\begin{array}{l}\text { N. } \\
R^{2}\end{array}$ & $\begin{array}{c}763.000 \\
0.181\end{array}$ & $\begin{array}{c}762.000 \\
0.066\end{array}$ & $\begin{array}{c}762.000 \\
0.206\end{array}$ \\
\hline
\end{tabular}

Weighted OLS. Standard errors clustered at the province-level reported in parentheses.

Covariates as described in Table S7. $+\mathrm{p}<0.10,{ }^{*} \mathrm{p}<0.05,{ }^{*} \mathrm{p}<0.01,{ }^{*} \mathrm{p}<0.001$ 
Table S22: Relationship between holding wrong beliefs and support for containment measures (Weighted)

\begin{tabular}{|c|c|c|c|}
\hline & $\begin{array}{c}\text { (1) } \\
\text { Social distancing: non-positive } \\
\text { b/se }\end{array}$ & $\begin{array}{c}\text { (2) } \\
\text { Isolation: positive } \\
\mathrm{b} / \mathrm{se}\end{array}$ & $\begin{array}{c}\text { (3) } \\
\text { Social distancing: elderly } \\
\text { b/se }\end{array}$ \\
\hline \multirow[t]{2}{*}{ How wrong (mean) } & $-0.247^{* *}$ & -0.021 & -0.191 \\
\hline & $(0.072)$ & $(0.019)$ & $(0.126)$ \\
\hline \multirow[t]{2}{*}{ Trust: science } & 0.013 & 0.003 & $0.014^{+}$ \\
\hline & $(0.009)$ & $(0.004)$ & $(0.007)$ \\
\hline \multirow[t]{2}{*}{ Trust: national government } & -0.002 & 0.001 & $0.009^{*}$ \\
\hline & $(0.003)$ & $(0.001)$ & $(0.004)$ \\
\hline \multirow[t]{2}{*}{ Trust: regional government } & $0.006^{*}$ & -0.000 & 0.001 \\
\hline & $(0.003)$ & $(0.001)$ & $(0.002)$ \\
\hline \multirow{2}{*}{ Trust: National Inst. Pub. Health } & 0.005 & 0.002 & $-0.008^{*}$ \\
\hline & $(0.007)$ & $(0.004)$ & $(0.004)$ \\
\hline \multirow[t]{2}{*}{ Gender } & -0.051 & 0.008 & -0.003 \\
\hline & $(0.098)$ & $(0.057)$ & $(0.157)$ \\
\hline \multirow[t]{2}{*}{ Age } & 0.008 & $0.006^{* *}$ & 0.004 \\
\hline & $(0.007)$ & $(0.002)$ & $(0.006)$ \\
\hline \multirow[t]{2}{*}{ Secondary } & -0.130 & 0.040 & -0.014 \\
\hline & $(0.264)$ & $(0.089)$ & $(0.140)$ \\
\hline \multirow[t]{2}{*}{ Bachelor } & -0.070 & -0.083 & -0.073 \\
\hline & $(0.323)$ & $(0.123)$ & $(0.232)$ \\
\hline \multirow[t]{2}{*}{ Master and Higher } & -0.450 & -0.074 & $-0.261^{+}$ \\
\hline & $(0.269)$ & $(0.107)$ & $(0.153)$ \\
\hline \multirow[t]{2}{*}{ Married } & 0.332 & 0.016 & 0.174 \\
\hline & $(0.406)$ & $(0.071)$ & $(0.192)$ \\
\hline \multirow[t]{2}{*}{ Cohabitation } & $0.438^{+}$ & 0.053 & 0.075 \\
\hline & $(0.258)$ & $(0.039)$ & $(0.169)$ \\
\hline \multirow[t]{2}{*}{ Divorced } & 0.122 & 0.038 & 0.110 \\
\hline & $(0.449)$ & $(0.093)$ & $(0.270)$ \\
\hline \multirow[t]{2}{*}{ Widow } & 0.386 & 0.000 & 0.800 \\
\hline & $(0.549)$ & $(0.138)$ & $(0.483)$ \\
\hline \multirow[t]{2}{*}{ Has children } & 0.092 & $-0.069^{*}$ & 0.082 \\
\hline & $(0.170)$ & $(0.032)$ & $(0.182)$ \\
\hline \multirow[t]{2}{*}{ Housewife } & $-0.944^{*}$ & 0.032 & -0.318 \\
\hline & $(0.451)$ & $(0.074)$ & $(0.259)$ \\
\hline \multirow{2}{*}{ Other } & $-0.658^{+}$ & $-0.138^{+}$ & -0.177 \\
\hline & $(0.355)$ & $(0.078)$ & $(0.254)$ \\
\hline \multirow[t]{2}{*}{ Employed } & -0.498 & -0.034 & -0.395 \\
\hline & $(0.370)$ & $(0.069)$ & $(0.247)$ \\
\hline \multirow[t]{2}{*}{ Retired } & -0.087 & -0.147 & $-1.040^{*}$ \\
\hline & $(0.416)$ & $(0.092)$ & $(0.420)$ \\
\hline Student & -0.410 & -0.074 & $-0.349^{+}$ \\
\hline & $(0.281)$ & $(0.096)$ & $(0.186)$ \\
\hline Math skills & 0.062 & 0.131 & 0.036 \\
\hline & $(0.170)$ & $(0.113)$ & $(0.156)$ \\
\hline LR scale & -0.006 & 0.007 & $0.088^{* *}$ \\
\hline & $(0.024)$ & $(0.013)$ & $(0.032)$ \\
\hline Outbreak areas & -0.059 & 0.013 & $0.220^{*}$ \\
\hline & $(0.125)$ & $(0.051)$ & $(0.087)$ \\
\hline Lombardy & 0.133 & -0.025 & -0.073 \\
\hline & $(0.234)$ & $(0.053)$ & $(0.145)$ \\
\hline Veneto & 0.047 & -0.113 & -0.100 \\
\hline & $(0.226)$ & $(0.068)$ & $(0.162)$ \\
\hline Latitude & -0.090 & 0.021 & -0.021 \\
\hline & $(0.059)$ & $(0.021)$ & $(0.038)$ \\
\hline Constant & $11.746^{* * *}$ & $8.193^{* * *}$ & $9.332^{* * *}$ \\
\hline & $(2.536)$ & $(0.991)$ & $(1.660)$ \\
\hline N. & 763.000 & 762.000 & 762.000 \\
\hline$R^{2}$ & 0.198 & 0.064 & 0.233 \\
\hline
\end{tabular}

Weighted OLS. Standard errors clustered at the province-level reported in parentheses.

Covariates as described in Table S7. $+\mathrm{p}<0.10,{ }^{*} \mathrm{p}<0.05,{ }^{*} \mathrm{p}<0.01,{ }^{*} \mathrm{p}<0.001$ 
Table S23: Treatment effects: Information by experts, weighted

\begin{tabular}{|c|c|c|c|c|}
\hline & $\begin{array}{c}\text { (1) } \\
\text { Willing to update: Youths (d) } \\
\text { b/se }\end{array}$ & $\begin{array}{c}(2) \\
\text { Willing to update: Antibiotics (d) } \\
\text { b/se }\end{array}$ & $\begin{array}{c}(3) \\
\text { Willing to update: Parcels (d) } \\
\text { b/se }\end{array}$ & $\begin{array}{c}(4) \\
\text { Willing to update: Hands (d) } \\
\text { b/se }\end{array}$ \\
\hline Info: experts & $\begin{array}{c}-0.116^{*} \\
(0.056)\end{array}$ & $\begin{array}{c}0.092 \\
(0.071)\end{array}$ & $\begin{array}{l}-0.127^{*} \\
(0.048)\end{array}$ & $\begin{array}{c}-0.023 \\
(0.057)\end{array}$ \\
\hline Trust: science & $\begin{array}{c}0.005 \\
(0.003)\end{array}$ & $\begin{array}{l}0.006^{* *} \\
(0.002)\end{array}$ & $\begin{array}{c}0.004 \\
(0.003)\end{array}$ & $\begin{array}{c}-0.001 \\
(0.003)\end{array}$ \\
\hline Trust: national government & $\begin{array}{c}0.002 \\
(0.001)\end{array}$ & $\begin{array}{l}0.003^{*} \\
(0.001)\end{array}$ & $\begin{array}{c}-0.002 \\
(0.002)\end{array}$ & $\begin{array}{c}-0.004 \\
(0.003)\end{array}$ \\
\hline Trust: regional government & $\begin{array}{c}-0.000 \\
(0.001)\end{array}$ & $\begin{array}{c}-0.003^{* * *} \\
(0.001)\end{array}$ & $\begin{array}{c}0.001 \\
(0.001)\end{array}$ & $\begin{array}{l}-0.001 \\
(0.002)\end{array}$ \\
\hline Trust: National Inst. Pub. Health & $\begin{array}{c}-0.004 \\
(0.003)\end{array}$ & $\begin{array}{c}0.000 \\
(0.002)\end{array}$ & $\begin{array}{c}0.001 \\
(0.002)\end{array}$ & $\begin{array}{c}0.001 \\
(0.003)\end{array}$ \\
\hline Gender & $\begin{array}{l}-0.067 \\
(0.061)\end{array}$ & $\begin{array}{c}-0.022 \\
(0.060)\end{array}$ & $\begin{array}{l}-0.065 \\
(0.043)\end{array}$ & $\begin{array}{l}-0.063 \\
(0.059)\end{array}$ \\
\hline Age & $\begin{array}{c}0.002 \\
(0.004)\end{array}$ & $\begin{array}{c}0.002 \\
(0.004)\end{array}$ & $\begin{array}{l}0.008^{* *} \\
(0.003)\end{array}$ & $\begin{array}{r}-0.008^{+} \\
(0.005)\end{array}$ \\
\hline Secondary & $\begin{array}{l}-0.181^{*} \\
(0.079)\end{array}$ & $\begin{array}{c}0.088 \\
(0.105)\end{array}$ & $\begin{array}{c}-0.401^{* * * *} \\
(0.094)\end{array}$ & $\begin{array}{c}-0.108 \\
(0.103)\end{array}$ \\
\hline Bachelor & $\begin{array}{c}-0.190^{+} \\
(0.105)\end{array}$ & $\begin{array}{c}0.142 \\
(0.113)\end{array}$ & $\begin{array}{l}-0.346^{*} \\
(0.137)\end{array}$ & $\begin{array}{c}-0.213^{+} \\
(0.117)\end{array}$ \\
\hline Master and Higher & $\begin{array}{l}-0.171^{*} \\
(0.064)\end{array}$ & $\begin{array}{c}0.182 \\
(0.137)\end{array}$ & $\begin{array}{c}-0.492^{* * * *} \\
(0.117)\end{array}$ & $\begin{array}{c}-0.166 \\
(0.101)\end{array}$ \\
\hline Married & $\begin{array}{c}-0.091 \\
(0.100)\end{array}$ & $\begin{array}{c}0.017 \\
(0.126)\end{array}$ & $\begin{array}{c}0.016 \\
(0.106)\end{array}$ & $\begin{array}{c}0.168 \\
(0.131)\end{array}$ \\
\hline Cohabitation & $\begin{array}{c}-0.060 \\
(0.118)\end{array}$ & $\begin{array}{c}0.008 \\
(0.106)\end{array}$ & $\begin{array}{l}0.162^{*} \\
(0.063)\end{array}$ & $\begin{array}{c}0.090 \\
(0.085)\end{array}$ \\
\hline Divorced & $\begin{array}{c}0.095 \\
(0.176)\end{array}$ & $\begin{array}{c}0.290 \\
(0.182)\end{array}$ & $\begin{array}{l}0.287^{*} \\
(0.109)\end{array}$ & $\begin{array}{c}0.154 \\
(0.136)\end{array}$ \\
\hline Widow & $\begin{array}{c}0.866^{* * *} \\
(0.155)\end{array}$ & $\begin{array}{l}-0.056 \\
(0.181)\end{array}$ & $\begin{array}{c}-0.359^{+} \\
(0.203)\end{array}$ & $\begin{array}{c}0.000 \\
(.)\end{array}$ \\
\hline Has children & $\begin{array}{c}0.071 \\
(0.083)\end{array}$ & $\begin{array}{c}0.109 \\
(0.092)\end{array}$ & $\begin{array}{c}-0.012 \\
(0.095)\end{array}$ & $\begin{array}{l}-0.020 \\
(0.094)\end{array}$ \\
\hline Housewife & $\begin{array}{l}-0.136 \\
(0.189)\end{array}$ & $\begin{array}{c}0.113 \\
(0.157)\end{array}$ & $\begin{array}{c}-0.646^{* *} \\
(0.188)\end{array}$ & $\begin{array}{c}-0.248^{+} \\
(0.147)\end{array}$ \\
\hline Other & $\begin{array}{c}0.134 \\
(0.188)\end{array}$ & $\begin{array}{c}-0.362^{* * *} \\
(0.100)\end{array}$ & $\begin{array}{l}-0.146 \\
(0.217)\end{array}$ & $\begin{array}{c}-0.227 \\
(0.139)\end{array}$ \\
\hline Employed & $\begin{array}{c}-0.116^{+} \\
(0.067)\end{array}$ & $\begin{array}{c}0.053 \\
(0.104)\end{array}$ & $\begin{array}{l}-0.095 \\
(0.082)\end{array}$ & $\begin{array}{l}-0.170 \\
(0.123)\end{array}$ \\
\hline Retired & $\begin{array}{c}-0.002 \\
(0.080)\end{array}$ & $\begin{array}{l}-0.343^{*} \\
(0.144)\end{array}$ & $\begin{array}{l}-0.086 \\
(0.137)\end{array}$ & $\begin{array}{c}0.285 \\
(0.214)\end{array}$ \\
\hline Student & $\begin{array}{l}-0.077 \\
(0.092)\end{array}$ & $\begin{array}{l}0.424^{* *} \\
(0.135)\end{array}$ & $\begin{array}{l}-0.007 \\
(0.094)\end{array}$ & $\begin{array}{l}-0.172 \\
(0.126)\end{array}$ \\
\hline Math skills & $\begin{array}{c}0.421^{* * *} \\
(0.100)\end{array}$ & $\begin{array}{c}0.393^{* * *} \\
(0.077)\end{array}$ & $\begin{array}{c}-0.266^{*} \\
(0.124)\end{array}$ & $\begin{array}{c}0.147 \\
(0.102)\end{array}$ \\
\hline LR scale & $\begin{array}{l}0.033^{* *} \\
(0.010)\end{array}$ & $\begin{array}{l}0.026^{+} \\
(0.014)\end{array}$ & $\begin{array}{l}0.038^{* * * *} \\
(0.009)\end{array}$ & $\begin{array}{c}0.005 \\
(0.016)\end{array}$ \\
\hline Outbreak areas & $\begin{array}{l}-0.007 \\
(0.069)\end{array}$ & $\begin{array}{c}0.127 \\
(0.105)\end{array}$ & $\begin{array}{l}-0.025 \\
(0.036)\end{array}$ & $\begin{array}{l}-0.011 \\
(0.061)\end{array}$ \\
\hline Lombardy & $\begin{array}{c}-0.370^{* * *} \\
(0.108)\end{array}$ & $\begin{array}{l}-0.176 \\
(0.107)\end{array}$ & $\begin{array}{l}-0.106 \\
(0.089)\end{array}$ & $\begin{array}{l}-0.020 \\
(0.073)\end{array}$ \\
\hline Veneto & $\begin{array}{c}-0.315^{* *} \\
(0.107)\end{array}$ & $\begin{array}{c}-0.206^{+} \\
(0.107)\end{array}$ & $\begin{array}{l}-0.129 \\
(0.095)\end{array}$ & $\begin{array}{l}-0.125 \\
(0.079)\end{array}$ \\
\hline Latitude & $\begin{array}{c}0.018 \\
(0.031)\end{array}$ & $\begin{array}{l}0.075^{*} \\
(0.031)\end{array}$ & $\begin{array}{c}-0.015 \\
(0.036)\end{array}$ & $\begin{array}{c}-0.015 \\
(0.019)\end{array}$ \\
\hline Constant & $\begin{array}{c}-0.938 \\
(1.444)\end{array}$ & $\begin{array}{c}-4.434^{* *} \\
(1.473)\end{array}$ & $\begin{array}{c}0.721 \\
(1.655)\end{array}$ & $\begin{array}{c}1.454 \\
(0.956)\end{array}$ \\
\hline N. & 302.000 & 361.000 & 480.000 & 336.000 \\
\hline$R^{2}$ & 0.790 & 0.360 & 0.665 & 0.312 \\
\hline
\end{tabular}

Weighted OLS. Standard errors clustered at the province-level reported in parentheses.

Covariates as described in Table S7. $+\mathrm{p}<0.10,{ }^{*} \mathrm{p}<0.05,{ }^{*} \mathrm{p}<0.01,{ }^{*} \mathrm{p}<0.001$ 
Table S24: Treatment effects: Information by experts

\begin{tabular}{|c|c|c|c|c|}
\hline & $\begin{array}{l}\text { (1) } \\
\text { Willing to update: Youths (d) } \\
\text { b/se }\end{array}$ & $\begin{array}{l}\text { Willing to update: Antibiotics (d) } \\
\text { b/se }\end{array}$ & $\begin{array}{c}\text { (3) } \\
\text { Willing to update: Parcels (d) } \\
\text { b/se }\end{array}$ & $\begin{array}{c}\text { (4) } \\
\text { Willing to update: Hands (d) } \\
\text { b/se }\end{array}$ \\
\hline Info: experts & $\begin{array}{c}-0.098^{* * *} \\
(0.026)\end{array}$ & $\begin{array}{c}0.040 \\
(0.056)\end{array}$ & $\begin{array}{c}-0.044^{+} \\
(0.025)\end{array}$ & $\begin{array}{c}0.043 \\
(0.030)\end{array}$ \\
\hline Trust: science & $\begin{array}{c}-0.001 \\
(0.002)\end{array}$ & $\begin{array}{l}0.006^{*} \\
(0.002)\end{array}$ & $\begin{array}{l}0.003^{+} \\
(0.001)\end{array}$ & $\begin{array}{c}0.002 \\
(0.001)\end{array}$ \\
\hline Trust: national government & $\begin{array}{c}0.002 \\
(0.001)\end{array}$ & $\begin{array}{l}-0.000 \\
(0.002)\end{array}$ & $\begin{array}{l}-0.001 \\
(0.001)\end{array}$ & $\begin{array}{c}-0.001 \\
(0.001)\end{array}$ \\
\hline Trust: regional government & $\begin{array}{c}0.001 \\
(0.001)\end{array}$ & $\begin{array}{l}-0.001 \\
(0.001)\end{array}$ & $\begin{array}{c}-0.001 \\
(0.001)\end{array}$ & $\begin{array}{c}0.000 \\
(0.001)\end{array}$ \\
\hline Trust: National Inst. Pub. Health & $\begin{array}{c}-0.003 \\
(0.002)\end{array}$ & $\begin{array}{l}-0.000 \\
(0.002)\end{array}$ & $\begin{array}{l}0.003^{+} \\
(0.002)\end{array}$ & $\begin{array}{c}-0.001 \\
(0.002)\end{array}$ \\
\hline Gender & $\begin{array}{l}-0.050 \\
(0.030)\end{array}$ & $\begin{array}{c}0.023 \\
(0.052)\end{array}$ & $\begin{array}{l}-0.050^{*} \\
(0.023)\end{array}$ & $\begin{array}{c}0.003 \\
(0.030)\end{array}$ \\
\hline Age & $\begin{array}{c}0.001 \\
(0.003)\end{array}$ & $\begin{array}{c}0.002 \\
(0.003)\end{array}$ & $\begin{array}{c}-0.001 \\
(0.002)\end{array}$ & $\begin{array}{l}-0.003 \\
(0.002)\end{array}$ \\
\hline Secondary & $\begin{array}{l}-0.059 \\
(0.092)\end{array}$ & $\begin{array}{c}0.067 \\
(0.144)\end{array}$ & $\begin{array}{l}-0.232 \\
(0.142)\end{array}$ & $\begin{array}{c}0.002 \\
(0.147)\end{array}$ \\
\hline Bachelor & $\begin{array}{l}-0.047 \\
(0.091)\end{array}$ & $\begin{array}{c}0.114 \\
(0.139)\end{array}$ & $\begin{array}{l}-0.193 \\
(0.142)\end{array}$ & $\begin{array}{l}-0.074 \\
(0.149)\end{array}$ \\
\hline Master and Higher & $\begin{array}{c}-0.032 \\
(0.090)\end{array}$ & $\begin{array}{c}0.099 \\
(0.142)\end{array}$ & $\begin{array}{l}-0.236 \\
(0.149)\end{array}$ & $\begin{array}{l}-0.074 \\
(0.149)\end{array}$ \\
\hline Married & $\begin{array}{c}0.066 \\
(0.115)\end{array}$ & $\begin{array}{c}0.035 \\
(0.095)\end{array}$ & $\begin{array}{c}0.030 \\
(0.085)\end{array}$ & $\begin{array}{c}0.023 \\
(0.104)\end{array}$ \\
\hline Cohabitation & $\begin{array}{c}0.056 \\
(0.097)\end{array}$ & $\begin{array}{c}0.079 \\
(0.101)\end{array}$ & $\begin{array}{c}0.074 \\
(0.051)\end{array}$ & $\begin{array}{c}-0.034 \\
(0.040)\end{array}$ \\
\hline Divorced & $\begin{array}{c}0.173 \\
(0.144)\end{array}$ & $\begin{array}{c}0.178 \\
(0.160)\end{array}$ & $\begin{array}{l}0.330^{* *} \\
(0.108)\end{array}$ & $\begin{array}{c}0.085 \\
(0.120)\end{array}$ \\
\hline Widow & $\begin{array}{c}0.920^{* * *} \\
(0.127)\end{array}$ & $\begin{array}{c}0.001 \\
(0.127)\end{array}$ & $\begin{array}{c}-0.089 \\
(0.162)\end{array}$ & $\begin{array}{c}0.000 \\
(.)\end{array}$ \\
\hline Has children & $\begin{array}{c}-0.099 \\
(0.085)\end{array}$ & $\begin{array}{c}0.006 \\
(0.091)\end{array}$ & $\begin{array}{c}0.043 \\
(0.081)\end{array}$ & $\begin{array}{c}0.023 \\
(0.084)\end{array}$ \\
\hline Housewife & $\begin{array}{c}0.075 \\
(0.214)\end{array}$ & $\begin{array}{c}-0.088 \\
(0.198)\end{array}$ & $\begin{array}{c}-0.327^{* * * *} \\
(0.093)\end{array}$ & $\begin{array}{c}-0.163^{+} \\
(0.087)\end{array}$ \\
\hline Other & $\begin{array}{c}0.060 \\
(0.156)\end{array}$ & $\begin{array}{l}-0.268 \\
(0.185)\end{array}$ & $\begin{array}{c}-0.096 \\
(0.112)\end{array}$ & $\begin{array}{l}-0.122 \\
(0.079)\end{array}$ \\
\hline Employed & $\begin{array}{c}0.037 \\
(0.058)\end{array}$ & $\begin{array}{l}-0.099 \\
(0.084)\end{array}$ & $\begin{array}{c}-0.106^{+} \\
(0.055)\end{array}$ & $\begin{array}{l}-0.055 \\
(0.070)\end{array}$ \\
\hline Retired & $\begin{array}{c}0.023 \\
(0.159)\end{array}$ & $\begin{array}{c}-0.400^{* * *} \\
(0.116)\end{array}$ & $\begin{array}{c}-0.094 \\
(0.132)\end{array}$ & $\begin{array}{c}0.189 \\
(0.119)\end{array}$ \\
\hline Student & $\begin{array}{c}0.045 \\
(0.056)\end{array}$ & $\begin{array}{l}0.158^{*} \\
(0.076)\end{array}$ & $\begin{array}{l}-0.064 \\
(0.058)\end{array}$ & $\begin{array}{l}-0.027 \\
(0.068)\end{array}$ \\
\hline Math skills & $\begin{array}{c}0.093 \\
(0.073)\end{array}$ & $\begin{array}{l}0.281^{* *} \\
(0.087)\end{array}$ & $\begin{array}{l}-0.100 \\
(0.089)\end{array}$ & $\begin{array}{l}-0.032 \\
(0.124)\end{array}$ \\
\hline LR scale & $\begin{array}{c}0.000 \\
(0.009)\end{array}$ & $\begin{array}{c}0.024 \\
(0.015)\end{array}$ & $\begin{array}{c}0.005 \\
(0.009)\end{array}$ & $\begin{array}{c}-0.009 \\
(0.006)\end{array}$ \\
\hline Outbreak areas & $\begin{array}{l}-0.021 \\
(0.029)\end{array}$ & $\begin{array}{c}0.089 \\
(0.054)\end{array}$ & $\begin{array}{l}0.133^{* *} \\
(0.041)\end{array}$ & $\begin{array}{c}0.033 \\
(0.070)\end{array}$ \\
\hline Lombardy & $\begin{array}{c}-0.073 \\
(0.071)\end{array}$ & $\begin{array}{c}-0.120^{+} \\
(0.068)\end{array}$ & $\begin{array}{l}-0.020 \\
(0.053)\end{array}$ & $\begin{array}{c}0.008 \\
(0.041)\end{array}$ \\
\hline Veneto & $\begin{array}{l}-0.101 \\
(0.073)\end{array}$ & $\begin{array}{l}-0.057 \\
(0.079)\end{array}$ & $\begin{array}{c}0.008 \\
(0.057)\end{array}$ & $\begin{array}{l}-0.012 \\
(0.046)\end{array}$ \\
\hline Latitude & $\begin{array}{c}-0.009 \\
(0.021)\end{array}$ & $\begin{array}{c}0.025 \\
(0.028)\end{array}$ & $\begin{array}{c}0.017 \\
(0.015)\end{array}$ & $\begin{array}{c}-0.030 \\
(0.026)\end{array}$ \\
\hline Constant & $\begin{array}{c}0.637 \\
(0.960)\end{array}$ & $\begin{array}{l}-1.763 \\
(1.338)\end{array}$ & $\begin{array}{c}-0.600 \\
(0.724)\end{array}$ & $\begin{array}{c}1.664 \\
(1.233)\end{array}$ \\
\hline $\begin{array}{l}\text { N. } \\
R^{2}\end{array}$ & $\begin{array}{c}302.000 \\
0.115\end{array}$ & $\begin{array}{c}361.000 \\
0.111\end{array}$ & $\begin{array}{c}480.000 \\
0.105\end{array}$ & $\begin{array}{c}336.000 \\
0.076\end{array}$ \\
\hline
\end{tabular}

OLS. Standard errors clustered at the province-level reported in parentheses. Covariates as described in Table S7. $+\mathrm{p}<0.10,{ }^{*} \mathrm{p}<0.05,{ }^{*} \mathrm{p}<0.01,{ }^{*} \mathrm{p}<0.001$ 
Table S25: Treatment effects: Information by experts, robustness

\begin{tabular}{|c|c|c|c|c|}
\hline & $\begin{array}{l}\text { (1) } \\
\text { Willing to update: Youths (d) } \\
\text { b/se }\end{array}$ & $\begin{array}{c}\text { Willing to update: Antibiotics (d) } \\
\text { b/se }\end{array}$ & $\begin{array}{c}\text { (3) } \\
\text { Willing to update: Parcels (d) } \\
\text { b/se }\end{array}$ & $\begin{array}{c}\text { (4) } \\
\text { Willing to update: Hands (d) } \\
\text { b/se }\end{array}$ \\
\hline Info: experts & $\begin{array}{c}-0.104^{* * * *} \\
(0.024)\end{array}$ & $\begin{array}{c}0.037 \\
(0.055)\end{array}$ & $\begin{array}{c}-0.050^{+} \\
(0.026)\end{array}$ & $\begin{array}{c}0.041 \\
(0.031)\end{array}$ \\
\hline Trust: science & $\begin{array}{l}-0.001 \\
(0.002)\end{array}$ & $\begin{array}{l}0.006^{*} \\
(0.002)\end{array}$ & $\begin{array}{l}0.003^{+} \\
(0.001)\end{array}$ & $\begin{array}{c}0.002 \\
(0.001)\end{array}$ \\
\hline Trust: national government & $\begin{array}{c}0.002 \\
(0.001)\end{array}$ & $\begin{array}{l}-0.000 \\
(0.002)\end{array}$ & $\begin{array}{l}-0.001 \\
(0.001)\end{array}$ & $\begin{array}{l}-0.001 \\
(0.001)\end{array}$ \\
\hline Trust: regional government & $\begin{array}{c}0.001 \\
(0.001)\end{array}$ & $\begin{array}{l}-0.001 \\
(0.001)\end{array}$ & $\begin{array}{l}-0.000 \\
(0.001)\end{array}$ & $\begin{array}{c}0.000 \\
(0.001)\end{array}$ \\
\hline Trust: National Inst. Pub. Health & $\begin{array}{l}-0.003 \\
(0.002)\end{array}$ & $\begin{array}{c}-0.000 \\
(0.002)\end{array}$ & $\begin{array}{l}0.003^{+} \\
(0.002)\end{array}$ & $\begin{array}{l}-0.001 \\
(0.002)\end{array}$ \\
\hline Gender & $\begin{array}{c}-0.053^{+} \\
(0.030)\end{array}$ & $\begin{array}{c}0.028 \\
(0.054)\end{array}$ & $\begin{array}{l}-0.047^{*} \\
(0.022)\end{array}$ & $\begin{array}{c}0.006 \\
(0.029)\end{array}$ \\
\hline Age & $\begin{array}{c}0.002 \\
(0.003)\end{array}$ & $\begin{array}{c}0.002 \\
(0.003)\end{array}$ & $\begin{array}{l}-0.001 \\
(0.002)\end{array}$ & $\begin{array}{l}-0.003 \\
(0.002)\end{array}$ \\
\hline Secondary & $\begin{array}{l}-0.063 \\
(0.089)\end{array}$ & $\begin{array}{c}0.060 \\
(0.140)\end{array}$ & $\begin{array}{l}-0.221 \\
(0.141)\end{array}$ & $\begin{array}{l}-0.001 \\
(0.149)\end{array}$ \\
\hline Bachelor & $\begin{array}{l}-0.050 \\
(0.092)\end{array}$ & $\begin{array}{c}0.110 \\
(0.137)\end{array}$ & $\begin{array}{l}-0.176 \\
(0.143)\end{array}$ & $\begin{array}{l}-0.074 \\
(0.152)\end{array}$ \\
\hline Master and Higher & $\begin{array}{l}-0.030 \\
(0.089)\end{array}$ & $\begin{array}{c}0.090 \\
(0.136)\end{array}$ & $\begin{array}{l}-0.224 \\
(0.148)\end{array}$ & $\begin{array}{l}-0.077 \\
(0.152)\end{array}$ \\
\hline Married & $\begin{array}{c}0.061 \\
(0.110)\end{array}$ & $\begin{array}{c}0.037 \\
(0.096)\end{array}$ & $\begin{array}{c}0.037 \\
(0.081)\end{array}$ & $\begin{array}{c}0.024 \\
(0.102)\end{array}$ \\
\hline Cohabitation & $\begin{array}{c}0.056 \\
(0.094)\end{array}$ & $\begin{array}{c}0.084 \\
(0.102)\end{array}$ & $\begin{array}{c}0.067 \\
(0.053)\end{array}$ & $\begin{array}{l}-0.035 \\
(0.040)\end{array}$ \\
\hline Divorced & $\begin{array}{c}0.133 \\
(0.141)\end{array}$ & $\begin{array}{c}0.187 \\
(0.162)\end{array}$ & $\begin{array}{l}0.329^{* *} \\
(0.106)\end{array}$ & $\begin{array}{c}0.086 \\
(0.117)\end{array}$ \\
\hline Widow & $\begin{array}{c}0.892^{* * *} \\
(0.119)\end{array}$ & $\begin{array}{c}0.010 \\
(0.126)\end{array}$ & $\begin{array}{l}-0.066 \\
(0.157)\end{array}$ & $\begin{array}{c}0.000 \\
(.)\end{array}$ \\
\hline Has children & $\begin{array}{c}-0.113 \\
(0.080)\end{array}$ & $\begin{array}{c}0.005 \\
(0.093)\end{array}$ & $\begin{array}{c}0.047 \\
(0.081)\end{array}$ & $\begin{array}{c}0.023 \\
(0.084)\end{array}$ \\
\hline Housewife & $\begin{array}{c}0.095 \\
(0.199)\end{array}$ & $\begin{array}{c}-0.079 \\
(0.198)\end{array}$ & $\begin{array}{c}-0.299^{* *} \\
(0.095)\end{array}$ & $\begin{array}{l}-0.158 \\
(0.097)\end{array}$ \\
\hline Other & $\begin{array}{c}0.023 \\
(0.163)\end{array}$ & $\begin{array}{c}-0.274 \\
(0.182)\end{array}$ & $\begin{array}{l}-0.112 \\
(0.112)\end{array}$ & $\begin{array}{l}-0.115 \\
(0.080)\end{array}$ \\
\hline Employed & $\begin{array}{c}0.032 \\
(0.055)\end{array}$ & $\begin{array}{l}-0.099 \\
(0.083)\end{array}$ & $\begin{array}{l}-0.109^{*} \\
(0.054)\end{array}$ & $\begin{array}{l}-0.052 \\
(0.072)\end{array}$ \\
\hline Retired & $\begin{array}{l}-0.001 \\
(0.145)\end{array}$ & $\begin{array}{c}-0.408^{* * *} \\
(0.116)\end{array}$ & $\begin{array}{l}-0.104 \\
(0.131)\end{array}$ & $\begin{array}{c}0.196 \\
(0.118)\end{array}$ \\
\hline Student & $\begin{array}{c}0.042 \\
(0.053)\end{array}$ & $\begin{array}{l}0.161^{*} \\
(0.079)\end{array}$ & $\begin{array}{l}-0.065 \\
(0.057)\end{array}$ & $\begin{array}{l}-0.026 \\
(0.069)\end{array}$ \\
\hline Math skills & $\begin{array}{c}0.054 \\
(0.068)\end{array}$ & $\begin{array}{l}0.282^{* *} \\
(0.086)\end{array}$ & $\begin{array}{l}-0.100 \\
(0.089)\end{array}$ & $\begin{array}{l}-0.029 \\
(0.127)\end{array}$ \\
\hline LR scale & $\begin{array}{c}0.001 \\
(0.009)\end{array}$ & $\begin{array}{c}0.023 \\
(0.016)\end{array}$ & $\begin{array}{c}0.005 \\
(0.009)\end{array}$ & $\begin{array}{c}-0.009 \\
(0.006)\end{array}$ \\
\hline Distance from outbreak areas & $\begin{array}{c}-0.001^{* * * *} \\
(0.000)\end{array}$ & $\begin{array}{c}-0.000 \\
(0.000)\end{array}$ & $\begin{array}{l}-0.000 \\
(0.000)\end{array}$ & $\begin{array}{c}0.000 \\
(0.000)\end{array}$ \\
\hline Lombardy & $\begin{array}{c}-0.119^{+} \\
(0.062)\end{array}$ & $\begin{array}{c}-0.115^{+} \\
(0.068)\end{array}$ & $\begin{array}{l}-0.013 \\
(0.056)\end{array}$ & $\begin{array}{c}0.017 \\
(0.044)\end{array}$ \\
\hline Veneto & $\begin{array}{l}-0.091 \\
(0.055)\end{array}$ & $\begin{array}{c}-0.056 \\
(0.082)\end{array}$ & $\begin{array}{c}0.019 \\
(0.057)\end{array}$ & $\begin{array}{l}-0.015 \\
(0.048)\end{array}$ \\
\hline Latitude & $\begin{array}{c}-0.106^{* * * *} \\
(0.030)\end{array}$ & $\begin{array}{c}0.014 \\
(0.049)\end{array}$ & $\begin{array}{l}-0.015 \\
(0.034)\end{array}$ & $\begin{array}{c}-0.019 \\
(0.033)\end{array}$ \\
\hline Constant & $\begin{array}{c}5.269^{* * *} \\
(1.492)\end{array}$ & $\begin{array}{l}-1.219 \\
(2.324)\end{array}$ & $\begin{array}{c}0.895 \\
(1.621)\end{array}$ & $\begin{array}{c}1.126 \\
(1.597)\end{array}$ \\
\hline $\begin{array}{l}\mathrm{N} . \\
R^{2}\end{array}$ & $\begin{array}{c}302.000 \\
0.144\end{array}$ & $\begin{array}{c}361.000 \\
0.109\end{array}$ & $\begin{array}{c}480.000 \\
0.100\end{array}$ & $\begin{array}{c}336.000 \\
0.075\end{array}$ \\
\hline
\end{tabular}

OLS. Standard errors clustered at the province-level reported in parentheses. Covariates as described in Table S7. $+\mathrm{p}<0.10,{ }^{*} \mathrm{p}<0.05,{ }^{*} \mathrm{p}<0.01,{ }^{*} \mathrm{p}<0.001$ 
Table S26: Treatment effects: Information by experts, robustness (weighted)

\begin{tabular}{|c|c|c|c|c|}
\hline & $\begin{array}{c}\text { (1) } \\
\text { Willing to update: Youths (d) } \\
\text { b/se }\end{array}$ & $\begin{array}{c}(2) \\
\text { Willing to update: Antibiotics (d) } \\
\text { b/se }\end{array}$ & $\begin{array}{c}\text { (3) } \\
\text { Willing to update: Parcels (d) } \\
\text { b/se }\end{array}$ & $\begin{array}{c}\text { (4) } \\
\text { Willing to update: Hands (d) } \\
\text { b/se }\end{array}$ \\
\hline Info: experts (d) & $\begin{array}{l}-0.255^{*} \\
(0.113)\end{array}$ & $\begin{array}{c}0.060 \\
(0.058)\end{array}$ & $\begin{array}{c}-0.401^{* * *} \\
(0.072)\end{array}$ & $\begin{array}{c}0.003 \\
(0.021)\end{array}$ \\
\hline Trust: science & $\begin{array}{c}0.009 \\
(0.009)\end{array}$ & $\begin{array}{l}0.008^{* *} \\
(0.003)\end{array}$ & $\begin{array}{c}0.006 \\
(0.005)\end{array}$ & $\begin{array}{l}-0.001 \\
(0.001)\end{array}$ \\
\hline Trust: national government & $\begin{array}{c}0.001 \\
(0.003)\end{array}$ & $\begin{array}{l}0.004^{*} \\
(0.002)\end{array}$ & $\begin{array}{l}-0.004 \\
(0.004)\end{array}$ & $\begin{array}{l}-0.001^{*} \\
(0.001)\end{array}$ \\
\hline Trust: regional government & $\begin{array}{c}0.003 \\
(0.003)\end{array}$ & $\begin{array}{c}-0.004^{* *} \\
(0.001)\end{array}$ & $\begin{array}{c}0.002 \\
(0.003)\end{array}$ & $\begin{array}{l}-0.000 \\
(0.001)\end{array}$ \\
\hline Trust: National Inst. Pub. Health & $\begin{array}{l}-0.007 \\
(0.005)\end{array}$ & $\begin{array}{l}-0.001 \\
(0.002)\end{array}$ & $\begin{array}{l}0.010^{+} \\
(0.006)\end{array}$ & $\begin{array}{c}0.000 \\
(0.001)\end{array}$ \\
\hline Gender (d) & $\begin{array}{r}-0.095 \\
(0.148)\end{array}$ & $\begin{array}{c}0.017 \\
(0.052)\end{array}$ & $\begin{array}{l}-0.199 \\
(0.125)\end{array}$ & $\begin{array}{l}-0.045^{*} \\
(0.021)\end{array}$ \\
\hline Age & $\begin{array}{c}0.007 \\
(0.009)\end{array}$ & $\begin{array}{l}0.003 \\
(0.004)\end{array}$ & $\begin{array}{c}0.007 \\
(0.008)\end{array}$ & $\begin{array}{l}-0.007^{*} \\
(0.003)\end{array}$ \\
\hline Secondary (d) & $\begin{array}{l}-0.215^{*} \\
(0.098)\end{array}$ & $\begin{array}{c}0.035 \\
(0.121)\end{array}$ & $\begin{array}{c}-0.730^{* * *} \\
(0.130)\end{array}$ & $\begin{array}{l}-0.006 \\
(0.031)\end{array}$ \\
\hline Bachelor (d) & $\begin{array}{c}-0.184^{* *} \\
(0.064)\end{array}$ & $\begin{array}{c}0.129 \\
(0.180)\end{array}$ & $\begin{array}{c}-0.397^{* * *} \\
(0.075)\end{array}$ & $\begin{array}{r}-0.042^{+} \\
(0.022)\end{array}$ \\
\hline Master and Higher (d) & $\begin{array}{r}-0.173^{+} \\
(0.098)\end{array}$ & $\begin{array}{c}0.210 \\
(0.189)\end{array}$ & $\begin{array}{c}-0.589^{* * * *} \\
(0.104)\end{array}$ & $\begin{array}{c}-0.041^{+} \\
(0.022)\end{array}$ \\
\hline Married (d) & $\begin{array}{l}-0.418 \\
(0.323)\end{array}$ & $\begin{array}{c}0.012 \\
(0.133)\end{array}$ & $\begin{array}{c}0.255 \\
(0.269)\end{array}$ & $\begin{array}{l}0.115^{+} \\
(0.068)\end{array}$ \\
\hline Cohabitation (d) & $\begin{array}{l}-0.152 \\
(0.172)\end{array}$ & $\begin{array}{c}0.060 \\
(0.118)\end{array}$ & $\begin{array}{l}0.409^{* *} \\
(0.131)\end{array}$ & $\begin{array}{c}0.009 \\
(0.047)\end{array}$ \\
\hline Divorced (d) & $\begin{array}{c}0.006 \\
(0.308)\end{array}$ & $\begin{array}{c}0.405 \\
(0.307)\end{array}$ & $\begin{array}{l}0.658^{* * * *} \\
(0.118)\end{array}$ & $\begin{array}{c}0.297 \\
(0.272)\end{array}$ \\
\hline Has children (d) & $\begin{array}{c}0.053 \\
(0.188)\end{array}$ & $\begin{array}{l}0.057 \\
(0.111)\end{array}$ & $\begin{array}{l}-0.041 \\
(0.168)\end{array}$ & $\begin{array}{c}0.015 \\
(0.045)\end{array}$ \\
\hline Housewife (d) & $\begin{array}{c}0.309 \\
(0.775)\end{array}$ & $\begin{array}{c}0.207 \\
(0.265)\end{array}$ & & \\
\hline Other (d) & $\begin{array}{l}0.581^{*} \\
(0.287)\end{array}$ & $\begin{array}{c}-0.179^{* * *} \\
(0.038)\end{array}$ & $\begin{array}{c}-0.311^{* * * *} \\
(0.094)\end{array}$ & \\
\hline Employed (d) & $\begin{array}{c}0.011 \\
(0.221)\end{array}$ & $\begin{array}{l}-0.011 \\
(0.099)\end{array}$ & $\begin{array}{c}-0.335^{* *} \\
(0.129)\end{array}$ & $\begin{array}{l}-0.077 \\
(0.047)\end{array}$ \\
\hline Retired (d) & $\begin{array}{c}0.076 \\
(0.305)\end{array}$ & & $\begin{array}{l}-0.405^{*} \\
(0.166)\end{array}$ & $\begin{array}{l}0.596^{* *} \\
(0.218)\end{array}$ \\
\hline Student (d) & $\begin{array}{c}0.035 \\
(0.231)\end{array}$ & $\begin{array}{l}0.534^{*} \\
(0.220)\end{array}$ & $\begin{array}{c}-0.294^{*} \\
(0.143)\end{array}$ & $\begin{array}{l}-0.047^{*} \\
(0.024)\end{array}$ \\
\hline Math skills (d) & $\begin{array}{c}0.268^{* * *} \\
(0.072)\end{array}$ & $\begin{array}{c}0.241^{* * *} \\
(0.046)\end{array}$ & $\begin{array}{c}-0.189 \\
(0.197)\end{array}$ & $\begin{array}{c}0.036 \\
(0.030)\end{array}$ \\
\hline LR scale & $\begin{array}{c}0.046 \\
(0.032)\end{array}$ & $\begin{array}{l}0.050^{* *} \\
(0.018)\end{array}$ & $\begin{array}{c}0.092^{* * * *} \\
(0.020)\end{array}$ & $\begin{array}{l}0.009^{+} \\
(0.005)\end{array}$ \\
\hline Outbreak areas (d) & $\begin{array}{c}-0.149^{*} \\
(0.075)\end{array}$ & $\begin{array}{l}-0.054 \\
(0.069)\end{array}$ & $\begin{array}{c}-0.301^{* * * *} \\
(0.075)\end{array}$ & $\begin{array}{c}-0.030^{+} \\
(0.018)\end{array}$ \\
\hline Lombardy (d) & $\begin{array}{c}-0.484^{*} \\
(0.189)\end{array}$ & $\begin{array}{l}-0.176 \\
(0.111)\end{array}$ & $\begin{array}{l}-0.122 \\
(0.197)\end{array}$ & $\begin{array}{c}0.058 \\
(0.040)\end{array}$ \\
\hline Veneto (d) & $\begin{array}{c}-0.246^{* *} \\
(0.087)\end{array}$ & $\begin{array}{c}-0.148^{* *} \\
(0.056)\end{array}$ & $\begin{array}{c}-0.312^{*} \\
(0.133)\end{array}$ & $\begin{array}{c}0.012 \\
(0.058)\end{array}$ \\
\hline Latitude & $\begin{array}{c}0.042 \\
(0.046)\end{array}$ & $\begin{array}{c}0.145^{*} \\
(0.060)\end{array}$ & $\begin{array}{c}0.001 \\
(0.056)\end{array}$ & $\begin{array}{c}-0.002 \\
(0.015)\end{array}$ \\
\hline $\mathrm{N}$. & 302.000 & 352.000 & 472.000 & 325.000 \\
\hline
\end{tabular}

Weighted Logit (marginal effects). Standard errors clustered at the province-level reported in parentheses. Covariates as described in Table S7. $+\mathrm{p}<0.10,{ }^{*} \mathrm{p}<0.05,{ }^{*}$ $\mathrm{p}<0.01,{ }^{*} \mathrm{p}<0.001$ 
Table S27: Treatment effects: Information by experts, interactions, weighted

\begin{tabular}{|c|c|c|c|c|c|c|c|c|}
\hline & \multirow{3}{*}{$\begin{array}{c}\text { (1) } \\
\text { Youths } \\
\text { b/se }\end{array}$} & \multirow[t]{2}{*}{$(2)$} & \multirow[t]{2}{*}{$(3)$} & \multirow{2}{*}{\multicolumn{2}{|c|}{$\begin{array}{c}(4) \\
\text { Willing to update: }\end{array}$}} & \multirow[t]{2}{*}{$(6)$} & \multirow[t]{2}{*}{$(7)$} & \multirow[t]{2}{*}{$(8)$} \\
\hline & & & & & & & & \\
\hline & & $\begin{array}{c}\text { Antibiotics } \\
\mathrm{b} / \mathrm{se}\end{array}$ & $\begin{array}{c}\text { Parcels } \\
\mathrm{b} / \mathrm{se}\end{array}$ & $\begin{array}{l}\text { Hands } \\
\mathrm{b} / \mathrm{se}\end{array}$ & $\begin{array}{l}\text { Youths } \\
\text { b/se }\end{array}$ & $\begin{array}{l}\text { Antibiotics } \\
\mathrm{b} / \mathrm{se}\end{array}$ & $\begin{array}{c}\text { Parcels } \\
\mathrm{b} / \mathrm{se}\end{array}$ & $\begin{array}{l}\text { Hands } \\
\text { b/se }\end{array}$ \\
\hline Info: experts=1 & $\begin{array}{l}-0.049 \\
(0.378)\end{array}$ & $\begin{array}{c}0.489 \\
(0.533)\end{array}$ & $\begin{array}{l}-0.593 \\
(0.408)\end{array}$ & $\begin{array}{c}0.189 \\
(0.336)\end{array}$ & $\begin{array}{c}-0.348^{* *} \\
(0.101)\end{array}$ & $\begin{array}{c}0.177 \\
(0.125)\end{array}$ & $\begin{array}{l}-0.157^{*} \\
(0.069)\end{array}$ & $\begin{array}{l}-0.032 \\
(0.089)\end{array}$ \\
\hline Trust: science & $\begin{array}{c}0.005 \\
(0.005)\end{array}$ & $\begin{array}{l}0.009^{*} \\
(0.004)\end{array}$ & $\begin{array}{l}0.001 \\
(0.005)\end{array}$ & $\begin{array}{c}0.000 \\
(0.003)\end{array}$ & $\begin{array}{c}0.003 \\
(0.003)\end{array}$ & $\begin{array}{l}0.007^{* *} \\
(0.002)\end{array}$ & $\begin{array}{c}0.003 \\
(0.003)\end{array}$ & $\begin{array}{l}-0.000 \\
(0.003)\end{array}$ \\
\hline Info: experts $=1 \times$ Trust: science & $\begin{array}{l}-0.001 \\
(0.004)\end{array}$ & $\begin{array}{l}-0.005 \\
(0.006)\end{array}$ & $\begin{array}{l}0.005 \\
(0.005)\end{array}$ & $\begin{array}{l}-0.002 \\
(0.004)\end{array}$ & & & & \\
\hline Distance from outbreak areas & & & & & $\begin{array}{c}-0.002^{* * *} \\
(0.001)\end{array}$ & $\begin{array}{c}0.001 \\
(0.001)\end{array}$ & $\begin{array}{l}-0.001 \\
(0.001)\end{array}$ & $\begin{array}{c}0.000 \\
(0.001)\end{array}$ \\
\hline Info: experts $=1 \times$ Distance from outbreak areas & & & & & $\begin{array}{l}0.001^{* *} \\
(0.000)\end{array}$ & $\begin{array}{l}-0.001 \\
(0.001)\end{array}$ & $\begin{array}{c}0.000 \\
(0.000)\end{array}$ & $\begin{array}{c}0.000 \\
(0.000)\end{array}$ \\
\hline Constant & $\begin{array}{l}-0.758 \\
(1.357)\end{array}$ & $\begin{array}{l}-4.538^{* *} \\
(1.594)\end{array}$ & $\begin{array}{c}0.806 \\
(1.662)\end{array}$ & $\begin{array}{l}1.508^{+} \\
(0.846)\end{array}$ & $\begin{array}{c}8.557^{* * *} \\
(2.102)\end{array}$ & $\begin{array}{l}-8.191^{*} \\
(3.416)\end{array}$ & $\begin{array}{c}3.965 \\
(2.566)\end{array}$ & $\begin{array}{l}-0.381 \\
(2.588)\end{array}$ \\
\hline Controls & $\checkmark$ & $\checkmark$ & $\checkmark$ & $\checkmark$ & $\checkmark$ & $\checkmark$ & $\checkmark$ & $\checkmark$ \\
\hline N. & 303.000 & 362.000 & 481.000 & 339.000 & 303.000 & 362.000 & 481.000 & 339.000 \\
\hline$R^{2}$ & 0.782 & 0.361 & 0.658 & 0.306 & 0.806 & 0.369 & 0.661 & 0.308 \\
\hline
\end{tabular}

OLS. Standard errors clustered at the province-level reported in parentheses. Covariates as described in Table S7. $+\mathrm{p}<0.10,{ }^{*} \mathrm{p}<0.05,{ }^{*} \mathrm{p}<0.01,{ }^{*} \mathrm{p}<0.001$ 
Figure S14: Support for containment policies: Standardized Coefficients and weighted regression

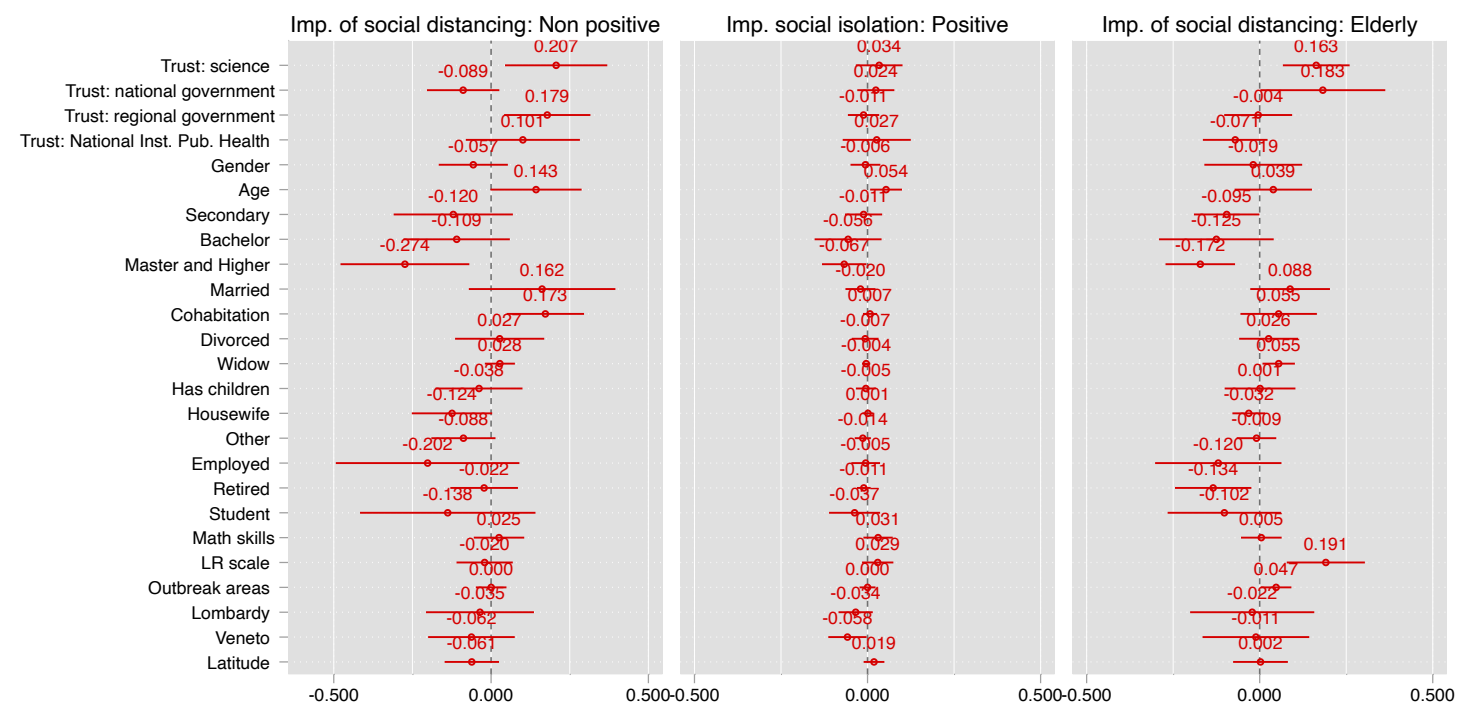

Figure S15: Determinants of wrong beliefs: Standardized Coefficients and weighted regression

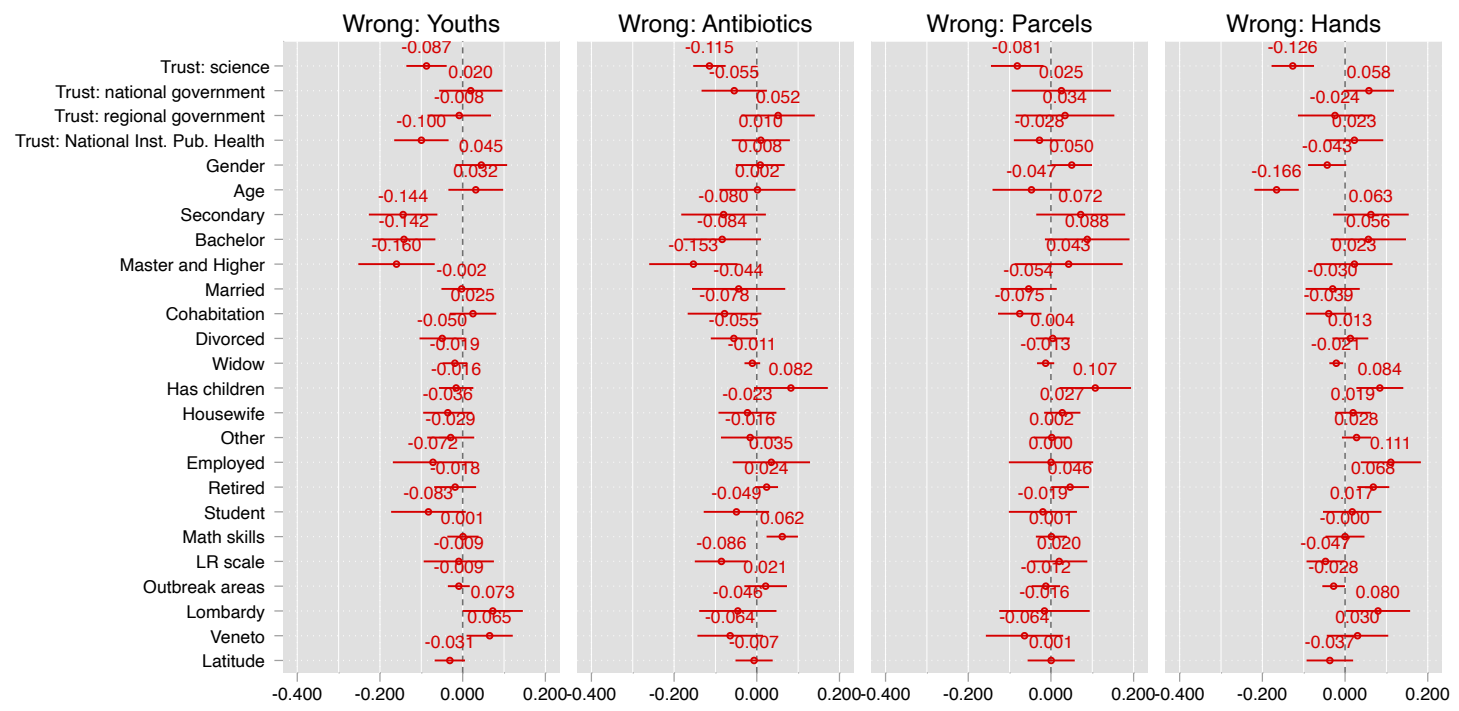


Table S28: Trust and perceived importance of social distancing measures: Only Lombardy with actual number of infected

\begin{tabular}{|c|c|c|c|}
\hline & $\begin{array}{c}\text { (1) } \\
\text { Social distancing: non-positive } \\
\text { b/se }\end{array}$ & $\begin{array}{l}\text { (2) } \\
\text { Isolation: positive } \\
\mathrm{b} / \mathrm{se}\end{array}$ & $\begin{array}{c}\text { (3) } \\
\text { Social distancing: elderly } \\
\mathrm{b} / \mathrm{se}\end{array}$ \\
\hline \multirow[t]{2}{*}{ Trust: science } & 0.014 & 0.004 & $0.013^{*}$ \\
\hline & $(0.009)$ & $(0.003)$ & $(0.005)$ \\
\hline \multirow[t]{2}{*}{ Trust: national government } & -0.003 & -0.000 & $0.014^{*}$ \\
\hline & $(0.004)$ & $(0.002)$ & $(0.005)$ \\
\hline \multirow[t]{2}{*}{ Trust: regional government } & 0.007 & -0.001 & -0.003 \\
\hline & $(0.004)$ & $(0.001)$ & $(0.003)$ \\
\hline \multirow[t]{2}{*}{ Trust: National Inst. Pub. Health } & 0.005 & 0.003 & -0.003 \\
\hline & $(0.009)$ & $(0.003)$ & $(0.005)$ \\
\hline \multirow[t]{2}{*}{ Gender } & -0.040 & 0.006 & 0.143 \\
\hline & $(0.133)$ & $(0.027)$ & $(0.269)$ \\
\hline \multirow[t]{2}{*}{ Age } & -0.002 & 0.005 & -0.001 \\
\hline & $(0.009)$ & $(0.003)$ & $(0.006)$ \\
\hline \multirow[t]{2}{*}{ Secondary } & $-0.436^{+}$ & -0.033 & -0.105 \\
\hline & $(0.200)$ & $(0.032)$ & $(0.082)$ \\
\hline \multirow[t]{2}{*}{ Bachelor } & -0.159 & -0.011 & 0.026 \\
\hline & $(0.271)$ & $(0.056)$ & $(0.276)$ \\
\hline \multirow[t]{2}{*}{ Master and Higher } & $-0.732^{*}$ & $-0.106^{*}$ & -0.259 \\
\hline & $(0.242)$ & $(0.037)$ & $(0.153)$ \\
\hline \multirow[t]{2}{*}{ Married } & $0.866^{+}$ & 0.016 & $0.448^{*}$ \\
\hline & $(0.416)$ & $(0.070)$ & $(0.177)$ \\
\hline \multirow{2}{*}{ Cohabitation } & $0.669^{* *}$ & 0.012 & $0.323^{+}$ \\
\hline & $(0.168)$ & $(0.040)$ & $(0.158)$ \\
\hline \multirow[t]{2}{*}{ Divorced } & 0.302 & 0.009 & 0.122 \\
\hline & $(0.603)$ & $(0.136)$ & $(0.389)$ \\
\hline \multirow[t]{2}{*}{ Widow } & 0.503 & 0.061 & 0.119 \\
\hline & $(0.507)$ & $(0.140)$ & $(0.310)$ \\
\hline \multirow[t]{2}{*}{ Has children } & -0.264 & -0.020 & -0.047 \\
\hline & $(0.186)$ & $(0.036)$ & $(0.146)$ \\
\hline \multirow[t]{2}{*}{ Housewife } & -0.479 & 0.027 & -0.305 \\
\hline & $(0.423)$ & $(0.035)$ & $(0.230)$ \\
\hline \multirow[t]{2}{*}{ Other } & $-0.775^{+}$ & -0.101 & -0.282 \\
\hline & $(0.391)$ & $(0.116)$ & $(0.277)$ \\
\hline \multirow[t]{2}{*}{ Employed } & $-0.721^{+}$ & $0.055^{+}$ & -0.330 \\
\hline & $(0.354)$ & $(0.026)$ & $(0.231)$ \\
\hline \multirow[t]{2}{*}{ Retired } & -0.296 & -0.142 & $-1.502^{*}$ \\
\hline & $(0.611)$ & $(0.097)$ & $(0.663)$ \\
\hline \multirow[t]{2}{*}{ Student } & $-0.755^{+}$ & 0.085 & -0.396 \\
\hline & $(0.370)$ & $(0.051)$ & $(0.273)$ \\
\hline \multirow[t]{2}{*}{ Math skills } & $-0.280^{+}$ & 0.035 & -0.409 \\
\hline & $(0.145)$ & $(0.068)$ & $(0.287)$ \\
\hline \multirow[t]{2}{*}{ LR scale } & -0.015 & 0.010 & $0.067^{*}$ \\
\hline & $(0.024)$ & $(0.006)$ & $(0.024)$ \\
\hline \multirow[t]{2}{*}{ Tot. cum. cases } & $0.012^{* *}$ & -0.004 & 0.002 \\
\hline & $(0.003)$ & $(0.003)$ & $(0.006)$ \\
\hline \multirow[t]{2}{*}{ Constant } & $8.561^{* * *}$ & $9.197^{* * *}$ & $8.290^{* * *}$ \\
\hline & $(0.487)$ & $(0.395)$ & $(0.322)$ \\
\hline N. & 454.000 & 454.000 & 454.000 \\
\hline$R^{2}$ & 0.201 & 0.096 & 0.325 \\
\hline
\end{tabular}

Weighted OLS. Standard errors clustered at the province-level reported in parentheses.

Covariates as described in Table S7. $+\mathrm{p}<0.10,{ }^{*} \mathrm{p}<0.05,{ }^{*} \mathrm{p}<0.01,{ }^{*} \mathrm{p}<0.001$ 
Table S29: Trust and wrong beliefs: Only Lombardy with actual number of infected

\begin{tabular}{|c|c|c|c|c|}
\hline & $\begin{array}{c}\text { (1) } \\
\text { Wrong: Youths } \\
\text { b/se }\end{array}$ & $\begin{array}{c}\text { Wrong: Antibiotics } \\
\text { b/se }\end{array}$ & $\begin{array}{c}\text { (3) } \\
\text { Wrong: Parcels } \\
\text { b/se }\end{array}$ & $\begin{array}{c}\text { (4) } \\
\text { Wrong: Hands } \\
\text { b/se }\end{array}$ \\
\hline Trust: science & $\begin{array}{c}-0.004^{+} \\
(0.002)\end{array}$ & $\begin{array}{c}-0.011^{* * *} \\
(0.002)\end{array}$ & $\begin{array}{c}-0.002 \\
(0.003)\end{array}$ & $\begin{array}{c}-0.006^{* *} \\
(0.002)\end{array}$ \\
\hline Trust: national government & $\begin{array}{l}-0.001 \\
(0.002)\end{array}$ & $\begin{array}{l}-0.003 \\
(0.003)\end{array}$ & $\begin{array}{l}-0.003 \\
(0.002)\end{array}$ & $\begin{array}{l}0.003^{+} \\
(0.001)\end{array}$ \\
\hline Trust: regional government & $\begin{array}{l}-0.001 \\
(0.002)\end{array}$ & $\begin{array}{c}0.002 \\
(0.002)\end{array}$ & $\begin{array}{l}0.004^{*} \\
(0.002)\end{array}$ & $\begin{array}{c}-0.003 \\
(0.002)\end{array}$ \\
\hline Trust: National Inst. Pub. Health & $\begin{array}{l}-0.005^{*} \\
(0.002)\end{array}$ & $\begin{array}{c}0.001 \\
(0.002)\end{array}$ & $\begin{array}{c}-0.001 \\
(0.002)\end{array}$ & $\begin{array}{c}0.002 \\
(0.002)\end{array}$ \\
\hline Gender & $\begin{array}{c}0.086 \\
(0.109)\end{array}$ & $\begin{array}{c}0.067 \\
(0.070)\end{array}$ & $\begin{array}{c}0.217^{* * *} \\
(0.041)\end{array}$ & $\begin{array}{c}-0.091 \\
(0.057)\end{array}$ \\
\hline Age & $\begin{array}{c}0.009^{*} \\
(0.003)\end{array}$ & $\begin{array}{c}0.003 \\
(0.004)\end{array}$ & $\begin{array}{l}-0.004 \\
(0.004)\end{array}$ & $\begin{array}{c}-0.010^{* *} \\
(0.003)\end{array}$ \\
\hline Secondary & $\begin{array}{c}-0.320^{+} \\
(0.151)\end{array}$ & $\begin{array}{l}-0.095 \\
(0.143)\end{array}$ & $\begin{array}{c}0.171 \\
(0.148)\end{array}$ & $\begin{array}{c}0.112 \\
(0.103)\end{array}$ \\
\hline Bachelor & $\begin{array}{l}-0.272 \\
(0.156)\end{array}$ & $\begin{array}{c}-0.198 \\
(0.150)\end{array}$ & $\begin{array}{c}0.167 \\
(0.171)\end{array}$ & $\begin{array}{c}0.005 \\
(0.121)\end{array}$ \\
\hline Master and Higher & $\begin{array}{l}-0.226 \\
(0.145)\end{array}$ & $\begin{array}{l}-0.271 \\
(0.177)\end{array}$ & $\begin{array}{c}0.097 \\
(0.167)\end{array}$ & $\begin{array}{l}-0.001 \\
(0.112)\end{array}$ \\
\hline Married & $\begin{array}{l}-0.019 \\
(0.090)\end{array}$ & $\begin{array}{c}-0.283 \\
(0.178)\end{array}$ & $\begin{array}{l}-0.192 \\
(0.112)\end{array}$ & $\begin{array}{l}-0.022 \\
(0.106)\end{array}$ \\
\hline Cohabitation & $\begin{array}{c}0.054 \\
(0.083)\end{array}$ & $\begin{array}{c}-0.302 \\
(0.175)\end{array}$ & $\begin{array}{c}-0.193 \\
(0.110)\end{array}$ & $\begin{array}{l}-0.038 \\
(0.082)\end{array}$ \\
\hline Divorced & $\begin{array}{l}-0.117 \\
(0.211)\end{array}$ & $\begin{array}{c}-0.366^{+} \\
(0.177)\end{array}$ & $\begin{array}{c}0.147 \\
(0.136)\end{array}$ & $\begin{array}{c}0.115 \\
(0.140)\end{array}$ \\
\hline Widow & $\begin{array}{c}0.006 \\
(0.500)\end{array}$ & $\begin{array}{c}-0.597^{* * *} \\
(0.111)\end{array}$ & $\begin{array}{c}-0.651^{*} \\
(0.225)\end{array}$ & $\begin{array}{l}-0.182 \\
(0.176)\end{array}$ \\
\hline Has children & $\begin{array}{c}-0.087 \\
(0.103)\end{array}$ & $\begin{array}{c}0.130 \\
(0.137)\end{array}$ & $\begin{array}{c}0.471^{* * *} \\
(0.086)\end{array}$ & $\begin{array}{c}0.200^{*} \\
(0.085)\end{array}$ \\
\hline Housewife & $\begin{array}{c}-0.494 \\
(0.275)\end{array}$ & $\begin{array}{c}-0.286 \\
(0.250)\end{array}$ & $\begin{array}{c}0.123 \\
(0.190)\end{array}$ & $\begin{array}{l}-0.106 \\
(0.128)\end{array}$ \\
\hline Other & $\begin{array}{l}-0.329 \\
(0.278)\end{array}$ & $\begin{array}{c}-0.019 \\
(0.220)\end{array}$ & $\begin{array}{c}0.086 \\
(0.084)\end{array}$ & $\begin{array}{c}0.203 \\
(0.171)\end{array}$ \\
\hline Employed & $\begin{array}{c}-0.255^{+} \\
(0.129)\end{array}$ & $\begin{array}{c}0.205^{*} \\
(0.084)\end{array}$ & $\begin{array}{c}0.008 \\
(0.081)\end{array}$ & $\begin{array}{l}0.240^{+} \\
(0.112)\end{array}$ \\
\hline Retired & $\begin{array}{c}-0.302 \\
(0.234)\end{array}$ & $\begin{array}{l}0.305^{+} \\
(0.165)\end{array}$ & $\begin{array}{c}0.290 \\
(0.165)\end{array}$ & $\begin{array}{c}0.636^{* * *} \\
(0.131)\end{array}$ \\
\hline Student & $\begin{array}{l}-0.107 \\
(0.146)\end{array}$ & $\begin{array}{l}-0.097 \\
(0.124)\end{array}$ & $\begin{array}{l}-0.089 \\
(0.070)\end{array}$ & $\begin{array}{c}0.119 \\
(0.100)\end{array}$ \\
\hline Math skills & $\begin{array}{c}0.109 \\
(0.154)\end{array}$ & $\begin{array}{c}0.539^{* * *} \\
(0.110)\end{array}$ & $\begin{array}{c}0.081 \\
(0.134)\end{array}$ & $\begin{array}{l}0.266^{*} \\
(0.116)\end{array}$ \\
\hline LR scale & $\begin{array}{l}-0.009 \\
(0.017)\end{array}$ & $\begin{array}{l}-0.020 \\
(0.022)\end{array}$ & $\begin{array}{c}0.018 \\
(0.012)\end{array}$ & $\begin{array}{l}-0.000 \\
(0.011)\end{array}$ \\
\hline Tot. cum. cases & $\begin{array}{c}0.005 \\
(0.004)\end{array}$ & $\begin{array}{c}0.004 \\
(0.003)\end{array}$ & $\begin{array}{l}-0.001 \\
(0.005)\end{array}$ & $\begin{array}{l}-0.005 \\
(0.003)\end{array}$ \\
\hline Constant & $\begin{array}{c}1.402^{* * *} \\
(0.274)\end{array}$ & $\begin{array}{l}1.121^{* *} \\
(0.353)\end{array}$ & $\begin{array}{c}0.532 \\
(0.418)\end{array}$ & $\begin{array}{l}0.592^{+} \\
(0.286)\end{array}$ \\
\hline N. & 454.000 & 380.000 & 451.000 & 454.000 \\
\hline$R^{2}$ & 0.328 & 0.323 & 0.318 & 0.321 \\
\hline
\end{tabular}

Weighted OLS. Standard errors clustered at the province-level reported in parentheses.

Covariates as described in Table S7. $+\mathrm{p}<0.10,{ }^{*} \mathrm{p}<0.05,{ }^{*} \mathrm{p}<0.01,{ }^{*} \mathrm{p}<0.001$ 
Figure S16: Support for containment and wrong beliefs: Standardized Coefficients and weighted regression

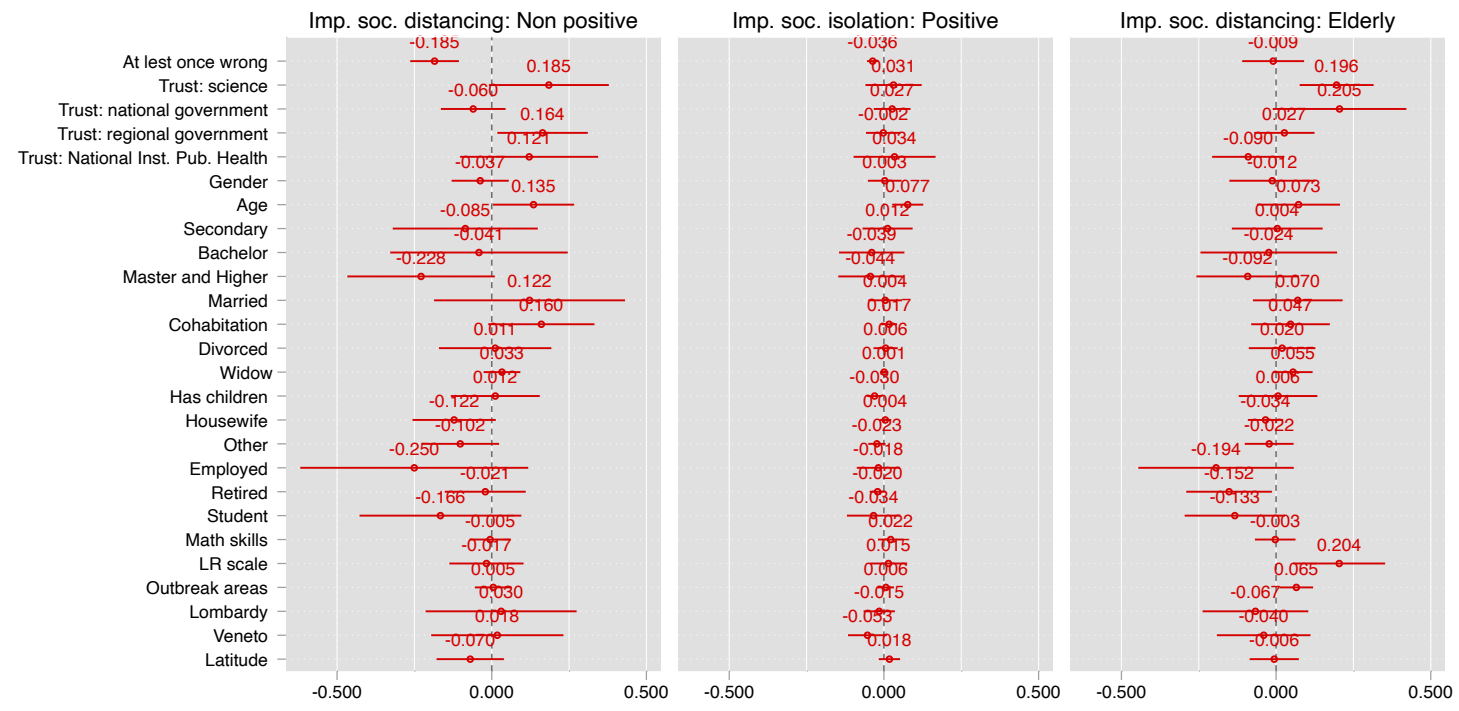

